"SIN MUJERES NO HAY REVOLUCIÓN"

TRANSVERSAL FEMINIST POLITICS IN THE DIGITAL MEDIATED ACTIVISM OF THE ARGENTINE COLLECTIVE NI UNA MENOS

\author{
A Dissertation \\ presented to \\ the Faculty of the Graduate School \\ at the University of Missouri-Columbia
}

In Partial Fulfillment

of the Requirements for the Degree

Doctor of Philosophy

by

AYLEEN A. CABAS-MIJARES

Dr. Cristina Mislán, Dissertation Supervisor

JULY 2019 
(C) Copyright by Ayleen A. Cabas-Mijares

All Rights Reserved 
The undersigned, appointed by the dean of the Graduate School, have examined the dissertation entitled

\section{"SIN MUJERES NO HAY REVOLUCIÓN" TRANSVERSAL FEMINIST POLITICS IN THE DIGITAL MEDIATED ACTIVISM OF THE ARGENTINE COLLECTIVE NI UNA MENOS}

presented by Ayleen Cabas-Mijares, a candidate for the degree of Doctor of Philosophy of Journalism, and hereby certify that, in their opinion, it is worthy of acceptance.

Assistant Professor Cristina Mislán

Associate Professor Yong Volz

Associate Professor Ryan Thomas

Associate Professor Victoria Johnson

Associate Professor Rebecca Martínez 


\section{ACKNOWLEDGEMENTS}

So, this is it. This is the culmination of work and sacrifice I cannot describe. My body and my mind feel the weight of what I am about to accomplish. A pressure has been lifted and, yet, I need to sit down and process. I am tired. I am proud. I am excited. I am sleepy. I am profoundly grateful.

I will take this space to honor the people who have brought me here. Every person in these acknowledgements was instrumental for me to reach my potential. The cliché is true: I would not be here without these people. I hope I do justice to my beloved mentors and friends here.

There is no way Cristina is not the first. She made me, even when she will not admit it. Cristina always knew how to give me space to grow. She also knew when to put the pressure on. She simply understood me. She let me cry and rant. She healed me many times. Hers is a tough love, but love nevertheless. I want to make her proud forever because she deserves it. She deserves whatever praise I can earn in her name. So, here is my work and effort. If you see an impressive piece of thought here, know Dr. Cristina Mislán made it possible. She crafted this brain and sensibility first-hand and created a confident researcher and teacher. Not everyone can say that. She has a legacy.

The rest of my committee members have also left a big mark on me and my scholarship. Dr. Young Volz, I will always try to emulate her thoughtfulness and methodic ways. She helped me approach qualitative methods with confidence. Thank you for being a great role model for women scholars. Dr. Ryan Thomas is so helpful he writes papers about it! I will forever be grateful for the useful readings and discussions we 
always had. I also thank him for laughing so generously at my bad jokes. Dr. Victoria Johnson brought sociology into my life and that is nothing but a gift. Plus, she wrapped this valuable present with delightful sarcasm and wit, so what else can I ever ask for? Lastly, Dr. Rebecca Martínez showed me the struggle and the strength you need to survive and thrive in academia as a woman of color. She shows the hardship and the hope. Her openness and honesty helped me ground myself in this work. As a bonus, I want to acknowledge the work of Dr. Earnest Perry. His leadership and care gave me the confidence to grow bolder in this program. Knowing that he had my back allowed me to take risks and be me. In a world full of academics who try to 'tame' women of color, Dr. Perry enables our own ways in greatness.

Now is the time for my brother in arms, Rob. Robbie has been a blessing since day one. The laughter he has given me these three years has been life-saving. Our friendship is deep and true. It is healthy and level-headed. Robbie is all you will ever need when you shoot for greatness. He will humble you but never let you doubt yourself. He will take you seriously but lighten up the mood whenever necessary. He never let me despair. He gave me family when mine was away. I love Rob with all my heart, and I am forever grateful for him.

I also need to thank the Tigers that are gone. Dr. Rachel Grant... that's my sister! My God, her love is so reliable and genuine that it can scare you sometimes. We loved each other instantly, and that love took us through thin and thick. She also made a home for me in Columbia, and that is just priceless. Then, we have the Joy of my life, Dr. Joy Jenkins. The master of puns and hospitality. Joy taught me a lot about being a person devoted to the service of others. She makes people feel safe and welcomed in meaningful 
ways. I'd trust her with my life. Plus, she made me make friends with a reverend, her husband, who will take care of my soul. In short, this is the best friendship bundle I've ever gotten!

The current Tigers earned big shout outs, too. Namyeon was the most beautiful addition to our cohort. She just brings balance to the force with her smile. Sarita, you are something else. My love for you runs deep and I am grateful for all the wine and the confidence you've given me. Joe, thanks for pushing me to think so deeply about scholarship and life. I hope the messiness of life doesn't torment you much. To my Sociology folks - Nathan, Julien, Melina, Alexis, and Jen -, thank you for making me smarter and for feeding my desire for justice. Dorothy, Sue and Charlotte, my J-Library fairies! They have been so patient and helpful! I will never be able to repay them for all their kindness.

Outside the school, many people have kept me sane and pushing over the years. Mike Sweeney, you guide my heart. Thank you for being a light in my life. Alicia Gatts, boo, thanks for the sisterhood, the healing and the salsa nights. Frank, hun, you give me invaluable love and peace. I love you. I love you. Mom, dad, Ashly, Celso, Sebas... we did it again. We keep breaking the mold and conquering. We'll keep leaving marks in the world, finding freedom and dignity. Seguiremos guarachando!

Finally, much respect and admiration must go to the activists involved in Ni Una Menos worldwide. These people put their bodies in the frontlines of the fight for liberation, and for that we are all indebted to them. All my appreciation goes to these extraordinary women. 
As I said before, my gratitude for the people in these acknowledgements is infinite. I will always try to honor the teachings, friendship and love I have been given. I am so happy to have shared such a defining part of my life with all of you. How lucky I was to end up at Mizzou! How lucky I am for having all of you! 


\section{TABLE OF CONTENTS}

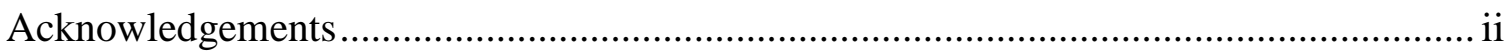

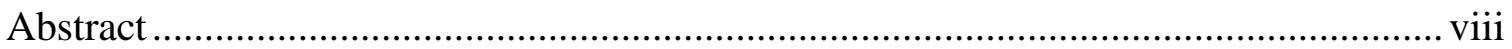

Chapter One: Introduction .................................................................................. 1

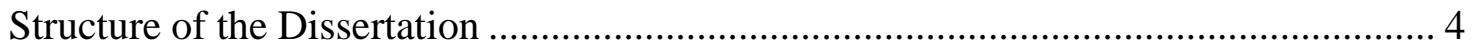

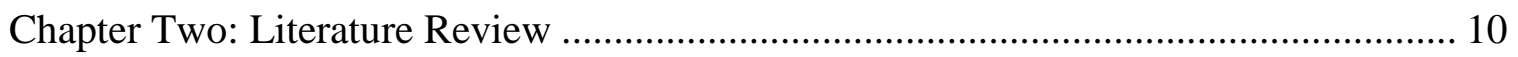

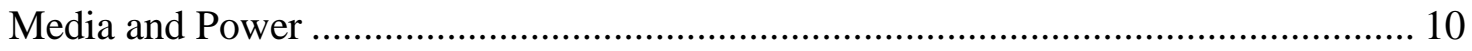

Mediated Activism in Shifting Media Environments ................................................ 15

Media and Journalism in Argentina..................................................................... 23

Feminism and Women's Movements in Latin America ................................................ 31

Intersectionality and Ni Una Menos: A Transnational Critique .................................. 40

Sharpening Intersectionality through Transversal Politics ....................................... 46

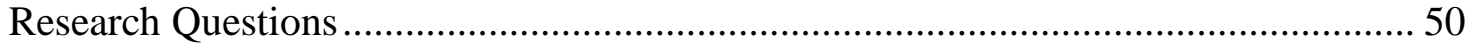

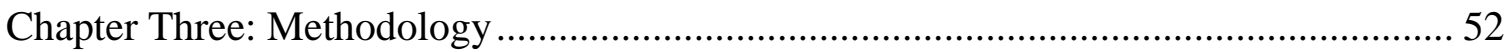

Postcolonial and Feminist Approaches to Ethnography ……………………….......... 55

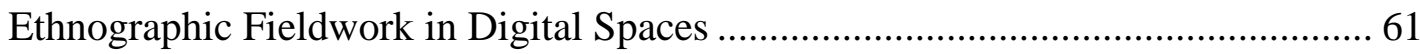

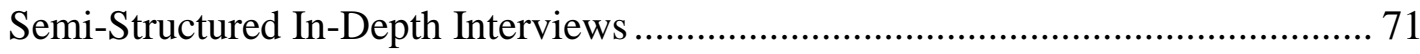

Critical Discourse Analysis.................................................................................. 74

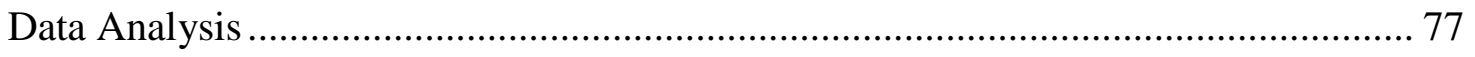


Chapter Four: The Transversal Politics of Ni Una Menos 80

Violencia Machista at the Core of Feminist Interventions ...................................... 81

Forming Collective Identity through Flexible Solidarities ..................................... 95

Embodying Transversal Feminist Politics in Argentina ........................................ 108

From Intersectional to Transversal Politics ...................................................... 109

The Digital Challenge to Transversal Politics ................................................... 116

Chapter Five: Transversal Feminist Politics Online: The Mediated Activism of Ni Una

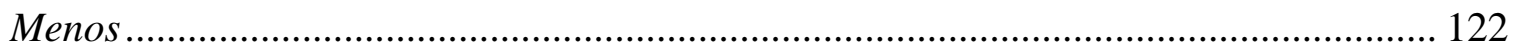

Taking Issue with Mainstream Media: Symbolic Violence as Violencia Machista ... 124

Targeting Journalism: Feminist Interventions in LatFem................................... 134

Digital Feminist Media Practices as a Corrective to Violencia Machista ................. 139

Media, Digital Communications, and Politics: Co-Structuring Fields ..................... 150

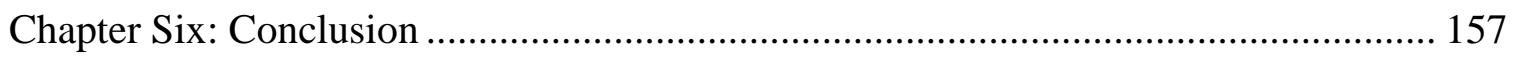

Methodological (Re)Considerations: Limitations and Suggestions ........................ 167

Closing Reflections about the State of Ni Una Menos (Buenos Aires) ..................... 170

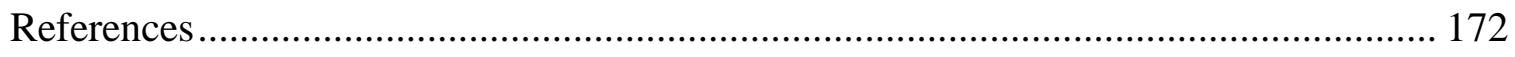

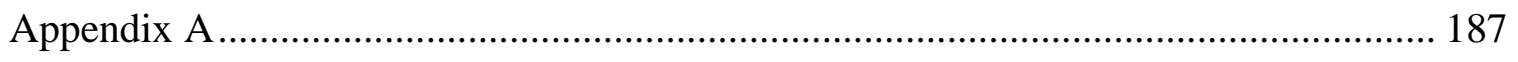

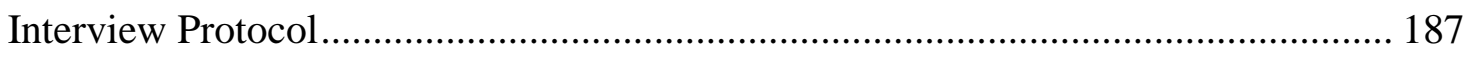

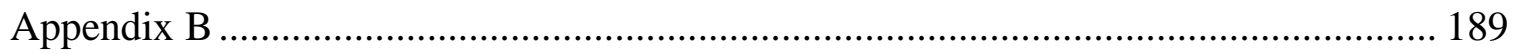

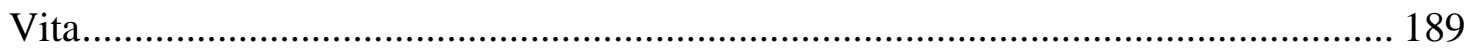


"SIN MUJERES NO HAY REVOLUCIÓN"

TRANSVERSAL FEMINIST POLITICS IN THE DIGITAL MEDIATED ACTIVISM

OF THE ARGENTINE COLLECTIVE NI UNA MENOS

Ayleen A. Cabas-Mijares

Cristina Mislán, Ph.D., Dissertation Chair

\begin{abstract}
While the advent of the Internet and digital social networks has opened opportunities for global connectivity, participation, and broadcasting to agents outside the media, corporations and the state, inequities structuring societies and transnational relations still organize the flows of power in digital environments. Media scholars who resist trends of technological determinism, have argued that, in the context of social movements, mediated activism is first propelled by the politics and positionalities of activists and second by the structural features of the media platforms they employ. Political praxis, then, informs the uses of media, guiding activists' narratives and strategies in mediated spaces. This dissertation examines such intersections of media and politics by conducting a case study about the Argentine feminist collective Ni Una Menos. The study shows that Ni Una Menos employed digital media discourses to focus activism on the single yet multifaceted issue of violencia machista whose many manifestations - from femicide to gender discrimination in the workplace - called for the


articulation of transversal coalitions. The application of such politics to mediated activism, however, posed its own challenges. The findings suggest that inequities structuring power differentials among members of different chapters of the collective i.e., class and professional status - shaped their mediated practices in a way that ensured the political and symbolic dominance of the Buenos Aires chapter of Ni Una Menos. The hypervisibility of NUM Buenos Aires nationally and internationally, despite contributing to global efforts against violencia machista, has also the potential to further marginalize the struggles of women outside the capitol who dwell more vulnerable nodes of intersectional oppression. These complicated entanglements call for critical examinations of the conditions under which mediated activism and transversal politics render emancipatory outcomes for some while undermining others. The case of $\mathrm{Ni}$ Una Menos offers an opportunity to engage in such reflections. 


\section{CHAPTER ONE: INTRODUCTION}

In May 11, 2015, the body of 14-year-old Chiara Páez was found buried in the patio of the family of her boyfriend's house in Santa Fe, Argentina. The post-mortem examination showed that she had died from beatings to the head, face and body. The tests also showed that she was pregnant. Her boyfriend, who was 16 years old at the time, confessed to the killing and was charged with aggravated murder, femicide and forced abortion ("How One Pregnant Teen's Murder," 2015). As horrendous as this story may seem, the case was somewhat typical. In 2015 alone, 235 women were murdered, and 3,746 women were raped in Argentina. Ninety-eight percent of femicide cases resulted in no convictions (Del Rio, 2016). Most of the victims were underage or young women (Rodríguez, 2015).

Chiara's death led a group of journalists, activists, and artists to turn to Twitter for catharsis. Marcela Ojeda, journalist for Radio Continental, sent out a tweet on May 11 that read: "Actresses, politicians, artists, businesswomen, social referents... women, everybody, bah... aren't we going to raise our voices? THEY ARE KILLING US.” The tweet sparked a domino effect. Using the hashtag \#NiUnaMenos (not one woman less), thousands of people signaled their will to protest femicide in multiple Argentine cities. A couple of weeks after Ojeda sent her tweet, 25 media professionals and members of women's non-profit organizations created the feminist collective Ni Una Menos to further coordinate collective action. Two weeks later, on June 3, 2015, massive protests under the slogan Ni Una Menos took place in at least 60 cities in Argentina. 
Massive mobilizations have not been the only mark of $\mathrm{Ni}$ Una Menos. The collective has worked with the Argentine government to enforce legislation and create public institutions to attend to cases of violence against women. Currently, there are selfsustaining and independent $\mathrm{Ni}$ Una Menos chapters in virtually every town in Argentina assisting women who are victims of violence and harassment (M. Ojeda, personal communication, March 23, 2019). Ni Una Menos has also collaborated with other major and historical feminist efforts in Argentina, such as the legalization of abortion. Furthermore, the collective has gained international recognition, having sister chapters in at least five countries in Latin America, and partnered up with feminist and women's movements worldwide. These transnational alliances gave Ni Una Menos a prominent role in the organization of the 2017 women's strike on International Women's Day.

The origin of Ni Una Menos resonates with Manuel Castells' (2012) theorizations about social movements of the networked society, which spontaneously "spread by contagion" on the Internet, fueled by the viral diffusion of images and ideas (p. 2). In observing movements such as Occupy and the Arab Spring, Castells (2012) argues that the interactive features and low-cost of the Internet have allowed networked social movements to find new paths to social change. Social movements in the digital era, Castells (2012) notes, tend to ignore political parties, distrust mainstream media, and resist hierarchical structuring. Instead, these movements focus on expressive activities online and the collaborative coordination of protest online and offline (Castells, 2015).

However, conceptualizing Ni Una Menos as a networked social movement focused on mediated expressive politics and struggles for symbolic power would ignore key elements of the collective's history and structure. Despite its nominal origins on 
social media, Ni Una Menos was not solely a product of online communication.

Historical legacies of the feminist and labor movements in Argentina informed the politics and collectivist forms of organizing of Ni Una Menos. Most of the individuals who sparked the online conversation after Chiara Páez's death were journalists who worked for mainstream media outlets. Some of them already self-identified as feminists and had ties with women's organizations, and national and regional feminist networks. In her compilation of interviews with Ni Una Menos founders and members, Paula Rodríguez (2015) shows that the collective's heterogenous yet conveniently networked founders capitalized on their past connections and media savviness to achieve large demonstrations and an arguably strong political pull. A Castellian account of networked social movements in the digital era, then, would render an ahistorical understanding of the role of digital technologies in social movements in general, and of the roots of $\mathrm{Ni}$ Una Menos in particular.

In this dissertation, I conduct a case study of $\mathrm{Ni}$ Una Menos to investigate how mediated discourses and activism along with histories of national and regional feminism were co-constitutive forces of the politics of this collective. Ni Una Menos, as a contemporary instance of feminist mediated activism in Latin America, provides opportunities for the study of the material and technological conditions that allow marginalized and minoritized constituencies to articulate and practice politics in digital environments. Furthermore, as $\mathrm{Ni}$ Una Menos has committed itself to intersectional (Crenshaw, 1989) and transversal (Yuval-Davis, 1999) feminism, the collective showcases sophisticated forms of feminist advocacy that have the potential to build stronger cross-organizational and cross-national coalitions that acknowledge and work 
through difference. The mediated activism of Ni Una Menos and the politics the collective has put behind it, then, present possibilities to resist the de-politization and neoliberal co-optation of feminist movements (Mohanty, 1986) that ought to be critically examined.

\section{Structure of the Dissertation}

In this section, I walk the reader through the major chapters of this dissertation and their main objectives and arguments. Starting with the literature review in chapter two, I put existing literature on mediated activism, social movements and feminism in conversation to give a solid foundation to my study of Ni Una Menos and its implications for media and politics. I particularly engage the arguments of media scholars who have found that communication technologies, digital and otherwise, are not only tools for expression in the public sphere but structuring elements that shape the opportunities and obstacles people face to exercise citizenship and activism (Waisbord, 2018).

Scholarship on mediated activism has focused on the ways that new communication technologies have disrupted the relationship between media and collective action (Earl \& Kimport, 2011). The argument holds that digital platforms have enabled new forms of activism and citizenship that were not possible in the times of analog media because the Internet has allowed certain constituencies to bypass the topdown, centralized structure of broadcast and print media. Before the advent of the Internet and digital social networks, mediated activism was limited to activists' efforts to gain visibility in a media environment that gave priority to the voices of government officials, economic elites and media workers (Ryan, 1991). Among these efforts, the development of alternative media - from zines to community radio - was key for activists 
who struggled to achieve nuanced self-representation (Atton, 2002; Downing, 2005; Lievrouw, 2011). As new communication technologies have allowed for the mediatization of almost every aspect of public life, they have also opened the doors to new opportunities for collective action and political expression (Couldry, 2003). Therefore, new communication technologies have enabled a qualitative shift in the history and methods of contentious politics (Tilly \& Tarrow, 2007).

However, scholars such as Tufecki (2017) and Waisbord (2018) have noted that the enthusiasm over digital technologies and their use by contemporary social movements have resulted in naïve celebrations of digital networks as inherently emancipatory tools. Waisbord (2018) specifies that research on digital activism has focused its attention on protest and expression while ignoring "the multidimensional and longitudinal impact of networked citizenship" (p. 3). Furthermore, Fenton (2016) and Trottier and Fuchs (2014) have called for the critical interrogation of digital activism vis-à-vis the politics of digital surveillance, the class dynamics that mediate Internet access and use globally, and the power of digital corporations and governments. It is necessary, then, to engage critical and sociological sensibilities in the study of mediated activism in order to see beyond episodic spectacles of protest and assess the historical and political context that shape and sustain social movements in the digital age (Waisbord, 2018).

This dissertation aims to contribute to such enterprise. My study presents a textured analysis that show the complex entanglements between mediated activism and feminist politics and histories in the case of Ni Una Menos. The dissertation departs from approaches to mediated activism that attribute the triumphs of recent social movements to the interactive, connective, participatory, and (arguably) democratic features of digital 
technologies. However, I do not dismiss the fact that features of and practices enabled by digital communication technologies can structure social relations and practices online and offline. Therefore, the focus of the dissertation is two-fold. First, I explore the situated understandings and histories of feminist politics in Argentina and Latin America to understand how they have grounded and shaped Ni Una Menos' mediated online discourses. Second, I focus on the mediated practices of Ni Una Menos to examine how these influence the politics of the collective. The study embarks, then, in an analysis of the mediated activism of the collective that is sensitive to situated understandings of the Argentine political and media system, and the history of the women's and feminist movements in Argentina to avoid ahistorical constructions of the collective's practices.

After discussing these contributions from literature, I present the methodology of this dissertation in chapter three. I chose case study as a research strategy to produce a "richly detailed, thick, and holistic elaborations and understandings of instances or variants" that shape the collective Ni Una Menos (Snow \& Trom, 2002, p. 152). Through the triangulation of multiple methods, I crafted a textured description and analysis of the mediated activism and politics of Ni Una Menos. Specifically, I drew from ethnographic, interview, and online textual data. I conducted a virtual ethnography (Hine, 2000, 2015), informed by feminist and postcolonial theory and ethics (Manning, 2016), to determine how Ni Una Menos constructed communities, collective identities, and paths for collective action in its digital spaces. Semi-structured in-depth interviews with founders and members of the collective allowed me to properly situate and contextualize my ethnographic observations and understand complex power dynamics within the collective. Finally, I conducted a critical discourse analysis - imbued with feminist 
sensibilities - of the content circulated in Ni Una Menos' digital spaces to assess how the collective constructs itself, its members, grievances and actions through mediated expression. In the findings chapters, I decided to put all these sources of data in conversation with one another to produce a narrative that reflects the complicated and sometimes paradoxical practices and outcomes that result from the mediated activism of Ni Una Menos.

In chapter four, I present the first set of findings of the dissertation, explaining how Ni Una Menos defined its own politics, grievances and notions of collective identity in its online discourses. The findings suggest that Ni Una Menos grounded its politics on a single yet multifaceted issue: violencia machista. The collective defined violencia machista as a structural set of conditions and systematic practices that (re)produce the political domination of women. Therefore, seemingly disparate or disconnected issues, such as the feminization of poverty, the criminalization of abortion, symbolic violence, sexual harassment and femicide, could be reconstructed as instances of violencia machista, entering the purview of Ni Una Menos.

This conceptualization was key for the collective to expand the range of its political interventions and strategic alliances. A relentless focus on the manifestations and effects of violencia machista as triggers for mobilization, allowed Ni Una Menos to construct a collective identity around goals and values, instead of identity and political positionalities. Consequently, Ni Una Menos embraced a type of inclusivity that enabled it to engage simultaneously in diverse struggles to end violencia machista in diverse arenas and locations. These flexible solidarities (Collins, 2017) defined the politics of $\mathrm{Ni}$ Una Menos as transversal. 
Now, in chapter five, where I delve into the mediated practices and activism of $\mathrm{Ni}$ Una Menos, the complexities and entanglements of mediated activism with existing regimes of visibility and oppression began to emerge. At the intersection of media and politics, I could observe how the uses and experiences of media - traditional and digital influence the grievances and tactics of diverse Ni Una Menos chapters. I found that NUM Buenos Aires, as compared to other chapters, engaged in mediated practices that boosted its status in both the national and digital media arena. Since this chapter is mostly constituted by media professionals, it could build symbiotic relationships with media and fully articulate feminist transversal politics through mediated discourses that include manifestos, research studies, and news articles. Other chapters of Ni Una Menos, on the other hand, did not count with the necessary networks and expertise to create productive relationships with the media. Therefore, the mediated activism of provincial $\mathrm{Ni}$ Una Menos chapters focused more on providing victims and their relatives with spaces where they can bring up their issues and fulfill their needs without risking their right to privacy.

The prominence of NUM Buenos Aires arguably undermines the position of provincial chapters. The success of the Buenos Aires group in gaining visibility has not reached the whole range of the collective. Furthermore, as this chapter increases its political pull and media profile, the chances of regional chapters of getting attention shrink and become more dependent on hyperbolical occurrences that can lend themselves to media spectacle. Digital communication technologies, so far, have not alleviated these disparities but aided them, giving media savvy activists from Buenos Aires more tools to articulate their political demands nationally and internationally, risking the invisibilization of the struggle of other chapters and constituencies. 
Finally, in chapter six, I present the conclusions of this case study. I delve into the broader theoretical and political implications of these findings and present some final reflections about my positionality in this study. Moreover, I discuss the limitations I encountered while doing this research and suggest paths for future research in the fields of media activism, feminism, and social movements.

Overall, this case study sheds light on the ways contemporary feminist politics and mediated activism have (re)constituted each other in the digital era in Argentina. The collective Ni Una Menos sits among an array of organizations and movements across the Latin American region that have attempted to bridge divisions of ideology, geography, class, ethnicity, race, sexuality and gender. Scholars such as Friedman (2017) have argued that Latin America provides a fertile ground for the study of transnational constructions of grievance, solidarity, and resistance as this geopolitical region is distinctively and tightly connected through it's a shared language and colonial history. Women's and feminist movements in this region are also of special interest as they have made major contributions to the transnational critique of neoliberal globalization and the articulation of women's rights as human rights; frameworks that have helped advance women's rights globally (Maier, 2010). Consequently, the study of Ni Una Menos allows scholars to fully engage critical and sociological theories to the assessment of media practices and environments that push progressive societal transformations. 


\section{CHAPTER TWO: LITERATURE REVIEW}

In this chapter, I present the literature that informs my case study of $\mathrm{Ni}$ Una Menos. The sections present existing research and debates on media power, mediated activism in digital environments, the Argentine media system, and intersectional and transversal feminist politics. The last section of the chapter presents the research questions that derive from this literature.

\section{Media and Power}

When thinking about the role of communication technologies in social change, scholars are often confronted with analytical dilemmas that trace back to assumptions and beliefs about the nature of media power. Manuel Castells (2015) has suggested that the media are not power holders themselves, but the platforms on which power is brokered. For Castells (2011), true power brokers utilize mediated communication to negotiate, affirm and legitimize their dominant position in society. Consequently, media constitute the vehicles through which power is enacted. Even though Castells recognizes media as powerful, he does not assign any inherent power to them. For Castells (2015), then, media are quite sharp swords that grant advantage to their holders as long as they practice good swordsmanship.

This view of media has been highly influential in and outside academia. Clay Shirky (2008), for instance, in his book Here comes everybody: The power of organizing without organizations, has sung the praises of social media as empowering and emancipatory tools that allowed for the rise of movements like the Arab Spring or

Occupy. The focus on the capacities of new technologies, which enhance speed, 
connectivity, interaction, and affordability of communication, have led researchers like Shirky to contend that the creative use of media by activists has surpassed the importance of formal organization when it comes to the coordination of collective action.

Accounts like these have been heavily criticized by scholars who observe the onthe-ground politics and histories of social movements. For instance, Tufecki and Wilson (2012) in their study about the events that amounted to the seminal protests in Tahir Square, found that decades of grievances and underground communications - which included the secret circulation of coded letters and VHS videos - among dissenting citizens consolidated the political base that later demonstrated on Tahir Square. In analyzing Iran's so-called “Twitter revolution,” Morozov (2009) indicated that it was the politics and the networks behind social media use what sparked the movement, not the technologies employed. Other studies about the Arab spring (e.g., Papacharissi \& Oliveira, 2012) have provided some nuance when discussing the impact of social media in the movement. Although Twitter and Facebook had a significant role in shaping the political debate in Egypt and Tunisia (Howard et al., 2011), social media only provided a new and broader platform for the expression and (re)production of larger grievances and historical transformations fermenting in Arab societies since the 1960s (Douai, 2013). Focusing too closely on the connective features of social media, then, detracts from the analysis of the complex factors driving social unrest, such as corruption and repression, more than technological innovation.

Wolfsfeld, Segev and Sheafer (2013) argue that, when considering the role of social media in social movements, "politics comes first" (p. 115). That is, the political environment defines whether social media will play a central or marginal role in the 
development of a social movement. This approach foregrounds the importance of context and history in the advance of social movements online. Furthermore, Morozov (2009) along with Tufecki and Wilson (2012) and others - argues that media are not inherently emancipatory or oppressive but connected to larger histories and politics that determine their structure and the chances of co-optation by social movements. Despite digital activism being useful for quick and far reaching engagement, scholars have found that it is not necessarily conducive to consistent actions to achieve social change, especially when activists become confronted with offline obstacles and the interests of other power brokers (Van Laer \& Van Aelst, 2010).

Through this critique, we get closer to the understandings of other scholars who do not see media as a value-free instrument for power holders and their challengers. These researchers, who are mostly in the field of sociology and media studies, consider media to be constitutive of existing power structures, especially in the new millennia when most social practices - including social resistance - have become dependent on the flow information and symbols (Couldry \& Curran, 2003). Bennett (2003), for instance, argues that the power of media must be assessed as it relates to other sources of power that structure modern societies. Drawing from the work of John Thompson (1995), Bennett (2003) argues that power manifests in four forms: political, economic, coercive, and symbolic. For Thompson (1995), none of these forms of power precedes the other. Differently from Marxist theories of base and superstructure, Thompson's power schema does not give prevalence to material forms of power over symbolic/ideological ones. This way, the four forms of power are co-constitutive and power brokers draw from them usually simultaneously - to sustain their dominance. 
In this framework, symbolic power represents the power to define reality (Bourdieu, 1991) and this power is negotiated mostly though communicative interaction (Luke, 2005). Media power falls under the umbrella of symbolic power as media - with the help of political and economic elites - have been structurally set up to reach mass publics within and across national borders and set the agendas and frames through which public affairs are understood and discussed. However, the media are not the only institutions able to use symbolic power, as governments and corporations can draw symbolic power through regulations and flows of capital (Bennett, 2003).

Considering this holistic understanding of power, Couldry (2003) argues that the study of social movements and their use of media must be undergirded by a concern about the concentration of symbolic and media power in particular social locations. In other words, he highlights the importance of asking who are the agents who have control over the flows and nature of information and how do they exercise that control? Couldry (2003) notes that scholars should not be blinded to these power dynamics when approaching social movements, as research has shown that activists who communicate and enact their politics on media already hold significant amounts of economic and cultural capital. Fenton (2016), in her analysis of digital activism, indicated that it was mostly middle- and upper-class individuals throughout the world who could advance their politics online. The issue, she argues, is not just one of access to the Internet or the technology; this pattern responds to privileged people's ability to articulate their politics credibly and to reach publics across national, cultural, and linguistic borders.

These debates about social movement media demonstrate unsettled understandings about the role of media in the constitution, development, and success of 
social movements. I argue that the issue here is of epistemological focus. If media is seen as a value-free instrument for activists, scholars are most likely foreground media's technological features - speed, interactivity, (trans)national reach, etc. - while ignoring the power dynamics that explain the processes that led to the emergence and nature of the technologies themselves. From this view, and not necessarily from empirical evidence, so-called "Twitter and Facebook revolutions" emerge (Tufecki, 2017). If, on the other hand, scholars observe the histories and political economy that constitute media systems, practices and technological features as well as oppositional politics and their structural transition to social movements, scholars are likely foreground the complex power dynamics in which - mainstream and activist - media are involved. This path, despite showing more promise for more sober analysis, exposes scholars to over-determination, which places almost absolute power in existing institutions and renders resistance virtually inconsequential (Ryan, 1991).

Elisabeth J. Friedman (2017) argues for bridging these apparently divergent understandings of media and activism by showing the way in which communication technologies are "constitutively entangled" with society (p. 5). In her investigations of Internet use among Latin American feminist and queer counterpublics, Friedman (2017) concludes that society does not determine technology, neither does technology determine society. Instead both of them are constitutive parts of processes of social becoming which are negotiated through relations among human and nonhuman elements (Friedman, 2017). Her ethnographic study of multiple feminist and queer organizations and networks, Friedman (2017) notes, exposed the "shifting entanglements" of individuals marked by their position in gender, race, class, and sexual hierarchies with technologies 
imbued in "utopian fantasies" and defined by structural inequalities (p. 6). The focus of research, then, turns to the ways in which the histories, values and lived experiences of communities inform their practices around technology and communication. Following social theorists such as Saskia Lassen and Robert Latham, Friedman (2017) defines this approach to technology and society as "sociomaterial" because it examines communication and technology practices within the context in which those practices are embedded in. This approach deeply informs this dissertation.

Considerations about material social realities that bring the analysis of media use out of the discursive field are key for a project like this one, where I investigate, in the broadest sense possible, how communication technologies and practices have shaped feminist politics as well as how feminist politics have shaped communication technologies and practices. Furthermore, the attention to the material responds to a Gramscian understanding of politics, which defines actions and interventions aimed at transforming power relations. Contentious or oppositional speech, therefore, does not become effectively political until it actively seeks to "alter the terrain of power" (Fenton, 2016, p. 7). Consequently, when examining the collective Ni Una Menos, I look not only at mediated discourses, but at organizational practices (including media practices) the collective engages in to intervene in the distribution and allotment of privilege and vulnerability across various groups in Argentine society.

\section{Mediated Activism in Shifting Media Environments}

Considering the benefits and pitfalls that come with differing understandings of media power, scholars studying social movement media should strive to seriously consider issues of structure vs. agency in their analyses of the connections between media 
and social change. This way, it is possible to assess the ways in which media technologies influence the strategies and practices of activists, without losing sight of the complex histories, geopolitics, economic and cultural factors that shaped media technologies and activists' grievances in the first place.

Activists usually enter struggles for symbolic power from a position of disadvantage, as their access to mainstream media ${ }^{1}$ is often limited or compromised by the lack the resources, logistical capabilities and reach that existing media organizations enjoy (Lievrouw, 2011). Despite the challenges, activists have always engaged in mediated activism as they attempt to amass political capital and, thus, achieve social transformation (Ryan, 1991). In this dissertation, mediated activism is broadly understood as the "uses of media technologies and institutions for collective action which includes expressing demands, giving visibility to identities, promoting dialogue, raising awareness about social problems and solutions, petitioning authorities, boycotting products, and advocating for policy and legal changes" (Waisbord, 2018). This concept of mediated activism allows to investigate the wide range of interactions, strategies, and goals that undergird activists' relationship with media.

Waisbord (2018) proposes to ignore political leaning when conceptualizing mediated activism in order to account for the ways in which media can serve a wide array of political purposes and ideologies. This conceptual move brings into focus the ways in which media shapes processes and structures that pertain to social movements rather than the objectives of such movements. In doing so, Waisbord (2018) argues, scholars can critically examine media strategies, framings and systems that fuel and/or hinder distinct

\footnotetext{
${ }^{1}$ I understand mainstream media as the body of media organizations that have become institutionalized over time as a result of their connection to political and economic elites.
} 
movements in distinct contexts and, thus, facilitate sober discussions about the sort of politics these uses of media enable. Taking political leaning out of the operationalization of media activism, then, opens a space for scholars to analytically compare and contrast instances of media activism without obscuring the role media technologies, regulations, institutions, and discourses play in the development of any movement within the leftright political spectrum.

A broad understanding of media activism like the one Waisbord (2018) proposes becomes particularly useful when considering how the Internet and digital communication technologies have impacted the structure and strategies of social movements across the globe. Before the advent of the Internet, two forms of mediated activism were dominant in academic inquiries: news and media advocacy, and alternative media (Waisbord, 2018). News and media advocacy target and aim to shape news coverage and media representations of movements, public issues, and solutions to influence public opinion around certain social issues and demands. This type of advocacy foregrounds the role of media and media power in the success or failure of social movements.

Gitlin (2003), in his study of the rise of the new left in America, voiced concerns about the relationship between mainstream media and activism. He posed that social movements faced a dilemma when engaging with mainstream media: they could ignore these platforms altogether or fully engage and challenge them. When following the first route, activists risked complete invisibility, while on the second route, activists risked overwhelming symbolic violence, assimilation or trivialization (Gitlin, 2003). These risks 
contributed to activists' strategic decision to create their own media platforms, in which they could engage in relatively independent processes of self-definition (Ryan, 1991).

Alternative media refers to citizen-led media platforms in which people can enact politics and cultures that are alternative to the mainstream (Atton, 2002). This way, the mediated expression of authentic and marginalized practices, identities, beliefs, and values fall under the umbrella of alternative media. Downing (2001) proposes a narrower understanding of alternative media as he advances his concept of radical alternative media. For Downing (2001), it is necessary to incorporate understandings of radical (oppositional or contentious) politics in conceptualizations of alternative media because, to put it simply, everything at some point is an alternative to something else. Downing's concern points to the creation of misleading categorical equivalencies between niche media, such as zines, and the media created by social movements. Radical alternative media are geared toward the articulation, expression, and distribution of radical politics, which usually emerge in opposition to the practices, goals, and priorities of the powers that be (Downing, 2001). Downing (2005) indicates that, since radical alternative media operates almost independently from political and economic elites, they have a better chance to circumvent censorship, include the voices of the marginalized, have nonhierarchical structures, and directly challenge the powerful.

This conceptualization of radical alternative media resonates with Natalie Fenton's (2016) elaborations of social movement media and their relationship with progressive politics. For Fenton (2016), no media can be considered radical if it is not geared toward actual social change. This complicates Castells' (2015) notion of expressive politics, which - in line with his view of media power - suggests that media 
are mere instruments for the expression of identity and grievance. The incorporation of radical/progressive politics to the concept of alternative media turn media - and communication - into performative structures that are intertwined in the constitution of social movements. Therefore, Fenton (2016) advocates for a critical evaluation of social movements and their media use as they are part of the forces that advance or hinder progressive politics and social justice.

In the predigital era, forms of media activism were studied under three main scholarly traditions, namely gatekeeping/organizational theory, political economy studies and cultural studies. Ryan (1991) argues that gatekeeping/organizational theories assign too much power to individuals in media organizations as they become the main autonomous agents in the selection and framing of the public agenda. Although this scholarly tradition has recently recognized that there are diverse power players outside the media field influencing media content - i.e., Silicon Valley, computer scientists, etc. (Russell, 2017) - there is still a tendency to see individual decision-making and technology as the setters of routines and practices within the media, which as we have seen leads to technological determinism (Tufecki, 2017). This way, gatekeeping/organizational studies, when observing social movement media, tend to focus their attention on the abilities of individuals and networks to use technologies to become included in news agendas (Ryan, 1991).

Political economy studies, on the other hand, place most responsibility on systemic factors when analyzing the production and effects of media content. Drawing from a structuralist tradition ${ }^{2}$, these studies foreground the operation of systems and

\footnotetext{
${ }^{2}$ Structuralism is concerned with the study structures, which are an arrangement of self-regulatory entities which possess internal coherence, the ability to enact transformational procedures (Piaget, 1971). In
} 
institutions in the configuration and organization of all aspects of social life, from human cognition to collective action (Hawkes, 2003). Herman and Chomsky's (1988) propaganda model, which suggests that media content in the U.S. responds to configurations of ownership, commercial business models, flacking, and anti-communist ideology, was especially influential in this field. These elaborations about media, matched structuralist approaches in social movement studies, such as resource mobilization and political opportunity theory, which saw media as mere strategic and tactic tools for activists (Benford, 1997). This framework leaves little to no room for effective resistance by minoritized and marginalized actors because the structural power concentrated in the hands of economic and political elites is always able to either co-opt or silence oppositional politics (Ryan, 1991).

Cultural studies offered a corrective to political economy's over-determination. Hall (1980) argued that cultural studies gave ideology, culture and lived-experiences a space in the articulation of the understandings that guide decision- and power-making in modern societies. As the struggle for power is an epistemological one as well, the power to define social reality, issues and responsibility is essential to control material conditions of existence (Hall, 1980). Consequently, it is necessary to assess not only the historical, economic and geopolitical conditions that define power structures, but the ways in which certain social actors in certain locations are able to articulate - the fairness or unfairness of - their positionalities in a given social network. Scholars, such as Paulo Freire, argued that one of the most powerful elements that lead people into collective action and

structuralist thinking, reality and meaning are a product of structural relationships; therefore, the main goal of structuralism is to understand "the permanent structures into which individual human acts, perceptions, stances fit, and from which they derive their final nature" (Hawkes, 2003, p. 7). 
organizing is the consciousness about one's disadvantaged position in the social fabric. Freire's (1967) work about conscientization, a process of political awakening that takes place through mediated and interpersonal communication, has been theorized as a key factor in the empowerment and mobilization of oppressed communities. This cultural turn, according to Jasper (2010), has had long-lasting effects on social movement research, as it has become virtually impossible for scholars theorizing about collective action to ignore the role of culture, ideology and meaning-making in the constitution and evolution of social movements.

To apply these understandings from cultural theory to the study of social movements, media scholars embraced the concept of frame alignment, which defined the processes by which organizers and recruits attempt to synchronize their views of a social problem and its solutions to coordinate collective action (Snow \& Benford, 1988). However, Benford (1997) warns that studies about social movement media and framing that follow this cultural tradition tend to neglect empirical comparative studies, and to incur in descriptive and elite bias, reification of framings and reductionism. To improve this area of scholarship, Benford (1997) suggested, among other things, to engage in longitudinal and transnational studies of social movement media, to move beyond the identification and description of frames and movements' discursive patterns, and to consider the contested dimensions of movement discourse.

With the advent of the internet and social media, conversations about mediated activism have shifted to consider activism in a media environment in which the lines between interpersonal and mediated communication have been blurred (Lievrouw, 2011). As the media environment is no longer entirely dominated by centralized media 
corporations that activist need to influence to garner visibility and support, digital technologies have indeed opened new paths for citizenship (Fenton, 2016; Waisbord, 2018). However, these paths have not been carved solely by the technological features of these digital networks. The creative and strategic practices of citizens in these digital spaces determine the transformative potential of new communication technologies (Fenton, 2016; Tufecki, 2017; Friedman, 2017).

Much concern has been raised about the ways in which digital media engenders trivial modes of online activism - or slacktivism - while demobilizing constituencies offline (Van de Donk et al., 2004). Furthermore, some scholars have noted that social media prevents activists from building strong relationships of loyalty and trust that are instrumental for the maintenance of social movements (Diani, 2000). However, a deep assessment of the on-the-ground power dynamics might yield more nuanced analyses and less techno-panics. For instance, studies have found that in oppressive environments, the anonymity and online interactivity that digital technologies provide are vital for the advancement of oppositional politics (Nip, 2004; Wojcieszak, 2009).

To study the role of media in social movements, then, it is necessary to engage in an analysis not only on the mediated discourses of oppositional politics - in mainstream or alternative media, online and offline - but on the historical and structural arrangements that have been conducive to the existence of such discourses. Therefore, in the following section, I present a brief account of the history and features of the Argentine media system. 


\section{Media and Journalism in Argentina}

To understand the media environment in which $\mathrm{Ni}$ Una Menos operates, it is necessary to examine the characteristics of Argentina's media system. To provide a comprehensive account of media systems worldwide, Hallin and Mancini $(2004,2012)$ have provided a helpful analytical framework that allows for the identification of forces that shape the structure, practices, and output of media institutions. Hallin and Mancini (2004) propose an analysis that focuses on four dimensions: (1) the development of media markets; (2) political parallelism; (3) the development of journalistic professionalism; and (4) the degree and nature of state intervention in the media system. The development of media markets covers the influence of the economic system of nations on the growth of media as an industry and evaluates the factors that account for its expansion, such as literacy levels, the emergence of commercial press, and the development of the advertising industry. Political parallelism addresses "the degree and nature of the links between the media and political parties" to examine the levels of political autonomy of the media (Hallin \& Mancini, 2004, p. 39). Journalistic professionalism refers to the broad standards of the profession. Finally, Hallin and Mancini (2004) examine the role of the state in the media system, which can be categorized in three non-mutually exclusive roles: owner, regulator, or funder.

To understand Argentina's media system, however, it is necessary to take a step back from this model and examine the recent political history of the country, which situates the Argentine media industry in an ongoing and expectedly flawed process toward democratization. From 1976 to 1983, Argentina was under the rule of an exceptionally repressive military junta whose legacy has left significant trauma in 
Argentine society (Jelin, 1994). During this dictatorship, extrajudicial detentions and concentration camps were common, and an estimate of between 15,000 to 30,000 people were killed - most of them still have not been found and are deemed "los desaparecidos." After the fall of his regime, the leader of the junta, José Rafael Videla, was charged for an array of human rights violations, including the theft of many babies born during the captivity of their mothers at illegal detention centers. These babies were then given in adoption to associates of the regime (Goñi, 2017).

During the dictatorship, opposition media was shut down and censorship was heavily enforced by the executive. Per the Broadcasting Law of 1980 - which remained in force until 2010 - broadcast media had to serve the needs of national security. News media organizations engaged in strict self-censorship and complied with the government's regulations to media content (Park, 2002). Some outlets with ties to the Catholic Church and the government did so willingly as these institutions supported the military regime (Andersen, 1993). The military took over the Federación de Trabajadores de Prensa (Press Workers Federation) and the state news agencies Sapotiri and Telam (Park, 2002). Those who did not abide by the regime's rules risked prison time, torture and death. Ultimately, in this time, at least 84 journalists were killed, and four hundred reporters fled the country (Knudson, 1997).

As the country transitioned to a democracy and struggled through an acute economic crisis in the 1980s, the economy and media organizations entered an era of liberalization (Macrory, 2013). The Carlos Menem administration (1989-1995) passed legislation mandating the privatization of all state-owned media and lifted restrictions to cross-media ownership, which prevented newspaper owners from gaining broadcast 
assets (Galperín, 2002; Marino, 2009). This legislation thwarted competition and enabled high levels of media conglomeration, allowing media companies like Grupo Clarín to dominate in print, radio, cable and satellite television (Vialey, Belinche \& Tovar, 2008). The media-government ties remained solid throughout subsequent democratic administrations, showing high levels of political parallelism.

However, it is worth noting that this symbiosis was based not only on economic benefits. Aggressions against the press did not come to a full stop after the transition to democracy. For instance, between 1991 and 1994, the press was subject to roughly 584 acts of aggression, including defamation accusations against journalists by government officials, termination of broadcast licenses, murder, death threats, bombings, bomb threats, intimidation, and physical violence (Delgado, 1995). In 1997, investigative journalist José Luis Cabezas was assaulted, assassinated and set on fire during his investigations on police corruption. Very few media outlets or journalists denounced the lack of government action in the wake of this murder or previous aggressions (Park, 2002).

The relationship between the media and the Argentine government started to become more strained during the center-left government of Néstor Kirchner (2003-2007) which enacted more regulatory oversight over the media. In 2005, the Kirchner administration allowed non-profit organizations to apply for broadcast licenses for the first time. Until then, a profit orientation had been a requisite to acquire a license (Mauersberger, 2011). Despite light impasses with the media, before the end of his presidency, Kirchner extended all broadcast licenses for ten years and allowed the merger 
of the two leading cable providers, Multicanal - owned by Grupo Clarín - and Cablevisión (Marino, 2009; Macrory, 2013).

The administration of Cristina Fernández disrupted the dealings between the government and the independent media. In 2008, President Fernández attempted to increase taxes on agricultural products, unleashing what today is known as the crisis del campo (the countryside crisis), a massive wave of protests by landowners and producers (Lewis, 2009). In their coverage, the outlets controlled by Grupo Clarín openly sided with the protestors. After losing the vote for her tax resolution in the Senate, President Fernández compared the rural strike to the one that catalyzed the 1976 coup d'état that put the military junta in power and added that the protestors were joined by "multimedia generals" instead of military tanks (Fernández as cited in Macrory, 2013, p. 182). From then on, the media became openly belligerent against the government (Becerra \& Mastrini, 2010).

Fernández responded by making moves to foreground the links between Grupo Clarín and other private media companies, such as the newspaper La Nación, to the military dictatorship and to undermine their dominance in the media oligopoly (see details in Macrory, 2013). In 2009, a new media law was passed, introducing stricter regulations to frequency allocation and media ownership. Some of the changes included a reduction of the maximum number of frequencies a legal person can own from 24 to 10 ; a prohibition on individuals and legal persons to own media that reaches $35 \%$ or more of the total population; limitations to cross-media ownership; and the allocation of one-third of the spectrum of every band (television, AM and FM radio) to non-profit organizations. 
Under the new law, media conglomerates like Grupo Clarín would have to sell assets and give up its monopolistic stance. Media moguls, however, are still fighting the regulations in the courts, characterizing them as threats to press freedom. However, Mauersberger (2011) in his analysis of these media regulations argues that the 2009 media law addressed issues of access and plurality that have undermined the democratic functions of Argentine media since the end of the military dictatorship.

After the end of Fernández presidency, the relationship between the government and the media has improved. Per Freedom House's 2017 report, the current administration of President Mauricio Macri has "reversed its predecessor's pattern of hostility toward the private media, resuming regular press conferences and ending official criticism and harassment of specific journalists." Furthermore, on September 2017, Congress passed a freedom of information bill aimed at improving public access to government documents (Freedom House, 2017).

Other changes in media law from the Fernández presidency targeted the nature of the Argentine media industry itself and are, thus, worth noting. The law of Audiovisual Services, passed in 2009, defined media as a public service, and access to information as a human right. The law further specified that it aims to "promote the protection and safeguard of equality between men and women, the plural, egalitarian and stereotype-free treatment, avoiding all gender and sexual discrimination" (as quoted in Hasan \& Gil, 2014, p. 47). Additionally, also in 2009, Argentina approved the Law of Integral Protection to Prevent, Sanction, and Eradicate Violence against Women, which defines and outlaws content that is discriminatory and offensive toward women in media as symbolic violence. 
The focus on the eradication of discrimination, and especially, gender discrimination, resulted not only from President Fernández's political platform as a woman advocating for women's rights, but also from decades of transnational work by feminists and women in the news industry. Feminist activists and reporters in Latin America had been establishing online feminist networks - sustained mainly by newsletters and email lists - since the early 1990s (Hasan \& Gil, 2014). After the IV United Nations World Conference in Beijing in 1995, in which media production was identified as one of the areas of critical intervention to achieve gender equality, these feminist networks multiplied across the region to expose and denounce the role of media and other elites in the systemic oppression of women (Hasan, 2012). As a result, in Argentina, groups such as Periodistas Argentinas en Red and the Red Internacional de Periodistas con Visión de Género emerged to advance the practice of feminist journalism in the country. These professional groups argued that feminist journalism develops "a series of specifically journalistic practices that denaturalize the supposedly neutral role of the news professional, build newsworthiness from a gender perspective, and provide a feminist critique of journalism institutions from a political perspective" (Hasan \& Gil, 2014). In their websites, these feminist networks share pedagogical material and other resources to help journalists and editors incorporate feminist understandings to their reporting. Feminism in this context is seen as the most effective tool to disrupt and curb symbolic violence against women and rape culture. Studies about these professional feminist digital networks remains scarce (Hasan \& Gil, 2014).

When it comes to assessing the development of journalistic professionalism (Hallin \& Mancini, 2004) in Argentina, the scarcity of studies on news work appears as 
the main obstacle. The lack of empirical research about this topic responds mostly to the late adoption of sociological approaches to the study of news media (Amado Suárez, 2012). According to Amado Suárez (2012), studies involving journalism in the region have favored critical and cultural perspectives that mostly analyze the ideological impact of news discourse and media ownership concentration. In her search for works that addressed the characteristics of news work and perceptions of journalists about their profession in Argentina, Amado Suárez (2012) found only 16 studies. Consequently, it is challenging to assess the processes and relationships that have constituted the journalism field vis-à-vis other fields of social life in Argentina.

Amado Suárez (2016) surveyed 363 Argentine journalists about their perceptions of journalism. The study found that most journalists value reporting the truth, promoting tolerance and cultural diversity, providing analyses of current affairs, allowing people to express their views, and monitoring and scrutinizing political leaders and business. Three out of four of this study's participants $(71.2 \%)$ perceived they had "either complete or a great deal of freedom" in their selection and framing of stories. Influences, such as personal values and beliefs (71\%), editorial policies $(59.7 \%)$, time constraints $(57.4 \%)$, owners or publishers $(50.5 \%)$, media laws $(32.3 \%)$, and advertising considerations (17.3\%), were noted by Argentine journalists (Amado Suárez, 2016). Referencing Amado Suárez’s book Argentine Journalisms (2017), journalist José Crettaz (2017) reported to La Nación that:

One third of the surveyed journalists earn less than US\$600 per month, and only three out of five are full-time reporters. Two of those five complement the profession with teaching. Only half have a college degree. Four out of ten Argentine journalists work for more than one newsroom, and some of them freelance for more than six newsrooms simultaneously. 
These numbers speak of an understaffed and overworked national news industry. Crettaz (2017) also referenced massive layoffs in the media industry in Argentina, with 1,499 jobs lost in recent years. Amado Suárez (2016) estimates there are around 5,525 working journalists in Argentina. ${ }^{3}$ When it comes to gender diversity in the newsroom, Argentina does not bode well, either. According to a 2015 study by the Global Media Monitor Project, $15 \%$ of news articles in the print industry were written by women, and only $35 \%$ of television news anchors are women (Alcaraz, 2017).

The fields of journalism and media in Argentina, then, are contested spaces where power has been exercised and brokered. Media have been an instrument for both authoritarian and democratic regimes, connecting media to processes of social control and power consolidation (Liotti, 2014). The push of the Fernández administration to dismantle media conglomerates like Grupo Clarín illustrates that in Argentina the media and media actors are a political force to reckon with, not mere vehicles where the power of other agents is negotiated. The status of Argentine mainstream news media as political - and sometimes partisan - actors is so prominent that journalism in the country is considered "militant," which signals a strong commitment in the industry to political advocacy and watchdog duties (Hasan \& Gil, 2014). The political outspokenness of Argentine news media can be interpreted as a response to the country's recent experiences with dictatorship, when freedom of expression and the press was virtually eliminated to fit the authoritarian impulses of the military regime.

The militant nature of Argentine news media and journalism has expanded beyond partisanship and state politics, however. The emergence of feminist journalism

\footnotetext{
${ }^{3}$ According to the World Bank, in 2016, Argentina's total population was around 43.85 million people.
} 
also advances the idea that the media - their institutions, organizations, and practices are spaces where women's struggle for equality take place. Thus, the regional and national feminist movement have recognized and targeted the media not only to render women's oppression visible, but to effectively disrupt violence against women.

\section{Feminism and Women's Movements in Latin America}

For centuries, women all over the world have been articulating their struggle against many types of inequalities to position themselves as citizens who, despite rejecting victimhood as the marker of their status, require institutional protection from existing systems of power that have rendered them vulnerable. The struggle of women globally, however, cannot be described or analyzed as one and the same. These struggles are plural, and their variations increase as different histories, politics, cultures, and socioeconomic conditions interact with the national, racial, class, religious, gender, and sexual identities of women.

Ni Una Menos has a place in the history of transnational struggles of the global South, and more specifically Latin America. Although feminist movements elsewhere have also been marked by diversity, the shared histories of Latin American countries which include more than 400 years of colonization that built similar patriarchal political and socioeconomic structures - have allowed feminist scholars and historians to create a somewhat cohesive narrative about the evolution of feminism in the region (Lebon, 2010). Although these shared regional histories provide necessary context for the analysis of social movements, it is necessary to strive for the highest levels of historical and geopolitical specificity when analyzing cases like Ni Una Menos. 
Amrita Basu (1995) noted that predominant Western literature about feminist history and theory has been erroneously one-sided, portraying feminists worldwide as a homogeneous group that fights for the same cause in similar ways. In doing so, Western literature has misrepresented women's movements in the postcolonial world and assumed that women's empowerment has been a product of neoliberal modernization and development (Basu, 1995). The neoliberalization of Latin American economies including Argentina's - led to foreign debt crises, waves of privatization, and an overall state constriction in the 1980s (Stephen, 1994). Consequently, more than a source of empowerment for women, neoliberal globalization has been a breeding ground for class discrimination and a catalyzer for women's revolt in the region (Lebon, 2010).

As Latin American governments struggled to enter the global capitalist market, they advanced policies that resulted in the deterioration of work conditions, the depreciation of salaries and the increase of unemployment (Colon \& Poggio, 2010). Men workers found themselves unemployed or underemployed and in need to migrate to find better opportunities (Maier, 2010). Many men abandoned their families all together. In this context, women were pushed into the labor force and had to operate under increasingly precarious work conditions in the formal and informal sectors to sustain their families. The precarity of women's labor and the limited opportunities for women to climb the socioeconomic ladder in these economies led to a process called the "feminization of poverty" in the region, which describes how neoliberal policies and the states' neglect of social programs disproportionately impacts women's ability to live with dignity (Maier, 2010, p. 33). 
Many female workers in Latin America had to engage in traditional agriculture, paid domestic work, or unskilled self-employment in the informal sector (Colon \& Poggio, 2010). None of these jobs provided women with legal protections or social welfare. On the contrary, these occupations exposed them to physical exploitation and violence, including sexual violence (Colon \& Poggio, 2010). Middle-class women only had access to low-level jobs in education, health and social services, which did not translate into a better social or economic status (Stephen, 1994). As Latin American women entered the labor force, the traditional female status and roles in society were redefined. Consequently, women became aware of the marginalization they were subjected to in all aspects of life, including their homes (Tripp, 2006).

Drawing from this new-found awareness, feminist groups started grassroots movements in their neighborhoods and workplaces to advocate for the needs of female workers (Maier, 2010). These groups, commonly called popular feminists, founded their activism on the intersection of gender and class. For them, feminist movements in Latin America could be united in the struggle against the global neoliberal system, which oppressed women as workers - based on the Marxist concept of alienation - and women as women, as patriarchal ideologies embedded in the neoliberal economic structure granted only men access to property (Maier, 2010).

The 1970s in Argentina were signed by the organized - and often violent resistance of labor and student movements against the military dictatorship of Juan Carlos Onganía. General Onganía, who took power in 1966 through a coup, harbored strong anti-communist policies and was particularly oppressive against trade unions and student activists. At the time, the country was also going through an acute economic recession in 
which the regime favored the economic interests of political and military elites (Delmonte Allasia, 2012). In this context and between 1970 and 1976, feminists organized in labor collectives which aimed to center the female experience in debates and struggles for labor rights. The most prominent collectives of the time were the Unión Feminista Argentina (UFA), Movimiento de Liberación Feminista (MLF), Movimiento Feminista Popular (MOFEP), and Frente de Izquierda Popular (FIP). These collectives showcased a horizontal organizational structure that resisted hierarchical stratifications and division of labor, as these arrangements were considered to be conducive to female oppression (Delmonte Allasia, 2012).

The Argentine feminist collectives focused on the organization of events to raise awareness about the struggle of women at home and at work, where their labor was either unpaid, underpaid or devalued (Tarducci \& Rifkin, 2010). The events included reading and debate sessions of feminist works, "volanteadas" (mass distribution of pamphlets), and conferences where the political dimensions of private life were foregrounded to articulate a new feminist consciousness (Nari, 1996; Campagnoli, 2005). The feminist collectives pushed for goals such as affordable child care, the ban of firings due to pregnancy, and compensation for home labor (Tarducci \& Rifkin, 2010). Reproductive rights and the legalization of abortion were in the agenda of the collectives as well (Tarducci \& Rifkin, 2010). Many women practiced "double militancy," being active in both feminist collectives and leftist political parties (Delmonte Allasia, 2012, p. 20). The UFA even joined forces with the Partido Socialista de los Trabajadores (PST) to coordinate some events and demonstrations. However, tensions would emerge around the partisan militancy of feminists as they were accused of infiltrating and depoliticizing 
labor movements to favor empty and non-revolutionary identity politics (Grammático, 2005). These tensions fueled feminists' denunciations against patriarchal stances within the left that attempted to silence and exclude women from the labor movement and the efforts to install democracy in Argentina (Delmonte Allasia, 2012).

After the 1976 military coup, however, the vigor of the feminist and labor movements stifled as the military regime systematically prosecuted, incarcerated and vanished dissidents of any kind. The military junta openly and systematically engaged in state terrorism to consolidate power. Nora A. Femenía (1987, p. 11) quotes General Ibérico Saint Jean, governor of Buenos Aires Province under the military saying, "First, we will kill all the subversives.... then, their collaborators; later, those who sympathize with them; afterward, those who remain indifferent; and finally, the undecided." Estimates of the number of people who disappeared and died during the seven years of the Dirty War range from 9,000 to 30,000 people (Rosemberg, 2016). As a result, many feminist collectives disbanded, and surviving organizations went underground or operated from exile barely sustaining reading and group discussions at the homes of activists (Belloti, 2005). Nari (1996) called this period of Argentine feminist activism “catacomb feminism." During the dictatorship, however, the militancy of Madres de Plaza de Mayo - an organization created in 1977 by mothers demanding the state to respond for their disappeared sons and daughters - politically weaponized motherhood as the grievance of mothers, in particular, and women, in general, cast a large shadow of illegitimacy on the military dictatorship in Argentina and abroad (Foss \& Domenici, 2001). 
On the international stage, feminist activism was undergoing key transformations. Women's and feminist organizations from all over the world were becoming increasingly institutionalized and establishing a presence in international forums, such as the UN and the OAS (Moghadam, 2000). As feminists from the global North and South convened in these forums, tensions over the nature of women's struggle arose. Western feminists prioritized the "need for legal equality and sexual autonomy" while non-Western feminists emphasized "imperialism and underdevelopment" as the sources of women's oppression (Moghadam, 2000, p. 61). Whereas feminists in the global South understood neoliberal globalization as a hindrance to women's advancement, feminists in the industrialized North believed neoliberalism to be an emancipating force that offered women an opportunity to obtain economic independence and, thus, escape traditional male control (Brenner, 2003).

These ideological clashes were evident at the first and second UN Conference of Women, which took place in Mexico City in 1975 and Copenhagen in 1980, respectively (Moghadam, 2000). However, as these international conferences continued, and strong transnational feminist networks emerged, Western feminists recognized the impact of economic conditions and foreign policies on women's lives while non-Western feminists fully incorporated body politics to their agendas (Moghadam, 2000). In 1981, in Latin America, feminist groups coordinated the first Encuentro Feminista Latinoamericano y del Caribe to advance feminist agendas catered to the histories and needs of the region. The Encuentros keep happening every year, and Argentina established its own Encuentros Nacionales de Mujeres in 1986, which are also still an annual occurrence (Delmonte Allasia, 2012). 
By the 1990s, the globalized feminist movement was prepared to articulate one of the most significant reinterpretations and reframings of the struggles of women worldwide to date. At the 1993 United Nations World Conference on Human Rights, feminist and women's groups agreed that a human rights framework was the most appropriate to address gender inequality worldwide (Alvarez, 1999). The framework was mostly advanced by women from the global South (Maier, 2010). The motto "women's rights are human rights" summarized this perspective and has allowed feminist activists to broaden understandings about the political, economic, social, and cultural causes and implications of tangible violations of the rights of women, such as wage gaps, inadequate access to birth control, domestic violence and femicide. In the fourth UN World Conference on Women in Beijing in 1995, feminist activists and NGOs crafted the Beijing Declaration and Platform for Action declaring that:

It is the duty of States, regardless of their political, economic and cultural systems, to promote and protect all human rights and fundamental freedoms. The implementation of this Platform, including through national laws and the formulation of strategies, policies, programmes and development priorities, is the sovereign responsibility of each State, in conformity with all human rights and fundamental freedoms, and the significance of and full respect for various religious and ethical values, cultural backgrounds and philosophical convictions of individuals and their communities should contribute to the full enjoyment by women of their human rights in order to achieve equality, development and peace (Platform for Action, 1996, Ch. II, para. 9).

With an internationally-accepted human rights framework, feminists could articulate wider sets of demands in their countries to eradicate many forms of violence against women. Amid the Argentine democratic transition, feminists could pressure the state to create in 1983 the Tribunal de Violencia contra la Mujer, a court specialized in gender violence, and in 1987 the Subsecretaría de la Mujer, a state department dedicated to creating policy to address women's grievances and needs (Delmonte Allasia, 2012). 
Tarducci and Rifkin (2010) noted that the 1980s and 1990s were key for Argentine feminists as they could unify the agendas of women across the socioeconomic and political spectrum to "render issues visible on the streets, in the media, and in the state, achieving various legal reforms" (p. 24). In this period, for instance, the Argentine state created the National Council of Women in 1991; established minimum quotas of female representation in government; reformed the Penal Code to prosecute cases of domestic violence and rape; and created programs to assist victims of gender violence (Tarducci \& Rifkin, 2010). These initiatives, however, have constantly been fraught with budgetary limitations as the state's neoliberal economic policies have consistently neglected social programs that target women and other marginalized communities in Argentina (Rofman, 2000). The issue of resource allocation continues to be a point of tension today as feminist groups, including Ni Una Menos, have attacked the Macri administration for furthering the neoliberalization of the Argentine economy and allowing the intervention of the International Monetary Fund.

Pushback against the feminist movement have come mostly from the Catholic Church and conservative social and political agents, especially as the topic of abortion has continued to be a priority for feminists in Argentina. The Encuentros in Latin America and Argentina had been foregrounding the need for the legalization of abortion and the creation of institutions and programs that guarantee the right of voluntary abortion, the reform of sexual education, and access to contraceptives (Tarducci \& Rifkin, 2010). In the early 2000s and as a product of the Encuentros in Argentina, the fight for reproductive rights became streamlined through the Campaña Nacional por el Derecho al Aborto legal, Seguro y Gratuito, a "federal alliance" that today comprises 
around 305 organizations in the country, including Ni Una Menos ("Quiénes Somos," n.d.). Since its inception, La Campaña has presented seven bill drafts to the Argentine Congress to legalize abortion for everyone, not just rape victims or women whose pregnancies are life-threatening, as established in the law since 1921. In August 2018, despite the approval of the Argentine House of Representatives, the Senate rejected the latest bill proposed by La Campaña after almost two years of public debate in which the Catholic Church and Catholic organizations spearheaded strong anti-abortion campaigns and mobilizations (Centenera, 2019). La Campaña and its supporters have characterized the state's blocking of legal, safe, and free abortions as violence, and frames the deaths of women for clandestine abortions or risky pregnancies as state-sanctioned femicide (Alcaraz, 2019).

As Ni Una Menos emerged with a focus on rape and femicide, a human rights framework, and adopted collectivist democratic structures to organize its activism, it pertains to these regional and national histories of the feminist movement. From the beginning, the members of the collective were eager to assess the intangible factors that contribute to violence against women, such as exploitative economic systems and patriarchal ideologies. Agustina Paz Frontera, one of the founders of $\mathrm{Ni}$ Una Menos, said in an interview for Remezcla: "When we talk about gender violence, the most terrible thing that can happen is that they kill you. But there's a whole framework before you reach that point" (Beately, 2017).

To target and disrupt that framework, $\mathrm{Ni}$ Una Menos has expressed a commitment to intersectional feminist politics. This becomes explicit in the digital discourses of the collective and its members. For instance, the mission statement of LatFem, a feminist 
news outlet ran by some members of the collective, states that "We do journalism from a feminist and intersectional perspective and we identify ourselves with the movement $\mathrm{Ni}$ Una Menos" (LatFem, n.d.). In an interview published by Esfera in 2016, Cecilia Palmeiro, founding member of $\mathrm{Ni}$ Una Menos, explained that intersectional feminist politics were key to forge alliances among diverse national and international activist groups which, in turn, expanded the reach of Ni Una Menos and the networks of solidarity it capitalized on to advance its own objectives in Argentina.

The horizontal, the non-representative, the transversal, that is, the construction of alliances and inclusion of different fronts of struggle, different contexts, different generations, religions, ethnicities, nationalities, languages, political trajectories, and the intersectionality that allows to understand forms of violence from different perspectives. The violence that middle-class urban women face is not the same that women in rural areas experience. We nourished ourselves with different experiences of feminism, of Black feminism, of indigenous feminism, which right now is leading environmental struggles against agricultural toxics and extractivism ("Feminismo, Cultura, Política," 2016).

The incorporation of intersectionality in the discourses and politics of $\mathrm{Ni}$ Una Menos call for a critical examination of the processes by which this feminist framework travelled from U.S. academic and popular culture circles to the Latin American context.

\section{Intersectionality and Ni Una Menos: A Transnational Critique}

Intersectionality has become extremely popular in both academic and nonacademic settings. Leslie McCall (2005) argues that intersectionality is one of the most important contributions of women's studies in history. Ange-Marie Hancock (2007) gives intersectionality the status of research paradigm, while Kathy Davis (2008) notes that the adoption of an intersectional framework in feminist scholarship has become a measurement of a study's theoretical soundness and relevance. Outside academia, intersectionality has been the conceptual foundation political demonstrations, such as the Women's March on Washington (Dastagir, 2017), and campaigns, such as 
\#SayHerName, \#WhyWeCantWait and \#SolidarityIsForWhiteWomen. The concept has even been used to critique celebrities' ill-conceived efforts to advocate for gender equality, such as Patricia Arquette's Oscar speech (McDonald, 2015), and Taylor Swift's Twitter feud with Nicki Minaj (Filipovic, 2015).

In the broadest sense, intersectionality has functioned as an analytical tool to examine how power dynamics structure privilege and vulnerability within and across axes of difference, such as race, gender, class and sexuality (Crenshaw, 1989, 1991). Intersectionality locates individuals' identities and lived experiences at the unmapped intersection of multiple categories of difference and their respective forms of oppression. As we all dwell in these intersections, the privilege and discrimination that we are afforded are the result of the continuous and context-dependent interaction of simultaneously racialized, gendered, queer- and trans-phobic, classed, nationalist, ableist, etc. understandings, policies and institutional structures. Consequently, as one aims to examine the inner workings of oppression, an intersectional framework sensitizes us to how forms of oppression are mutually constitutive and enforcing (Crenshaw, 1989).

Crenshaw (1991) has insisted that she did not coin intersectionality as a totalizing theory of identity. She argues that intersectionality is more valuable as a framework that bridges the tensions between the notion of multiple identities and the need for identity politics, which has traditionally - and misleadingly - clustered the interests of social groups based on a single-axis framework, ignoring intragroup diversity. Crenshaw's clarification reveals that behind the concept of intersectionality there is a commitment with social transformation and the better articulation of the grievances and goals that push social movements forward. The political nature of intersectionality is not only 
founded on Crenshaw's personal commitment to social justice, but from the theoretical influences that intersectionality is founded on, namely black feminism, critical race theory, and queer studies (Crenshaw, 1989). Consequently, when studying women's and feminist movements, intersectionality offers a distinct ontological understanding of power that calls for new epistemological approaches to the study of power dynamics, social structures and lived experiences.

Intersectionality has certainly sensitized scholars within the field of media and journalism studies to the intersectional nature of identity and oppression. In their study about the constitution of collective identities around political issues in the online movement \#SayHerName, Brown, Ray, Summers and Fraisat (2017) found that members of disadvantaged groups use intersectionality as a basis for consciousness raising and mobilization. As the hashtag \#SayHerName effectively exposed the injustices that targeted black women, intersectional thought functioned as both a community builder and political argument. This way, users of this hashtag had a readily available template for the articulation of solidarity, grievances and politics on Twitter (Brown et al., 2017). This paper, although insightful and relevant, is an example of studies that employ an intersectional framework for analysis can still fail to fulfill the political goals of intersectionality. By limiting the analysis to the discursive realm, the study fails to account for and challenge the material and political conditions that render Black women vulnerable in the United States.

Cho, Crenshaw and McCall (2013) argue that intersectionality, as a critical theory, should always find ways to holistically disrupt the power relations it helps unveil. Intersectionality is inherently geared toward both consciousness raising and political 
praxis, which turns it into an instrument for theoretical development and social justice advocacy. However, Carastathis (2016) has argued that intersectionality has frequently been co-opted by white feminists and neoliberal institutions to depoliticize discussions about power relations and turn them into empty recognitions and celebrations of diversity and pluralism.

Naturally, intersectionality is not the only critical theory open to neoliberal cooptation. Chandra Talpade Mohanty (2013) has persuasively argued that in the era of the "posts" - as in postmodernism, postfeminism, postintersectionality, etc. - the neoliberal marketplace of ideas has amassed much success in dismissing or domesticating the analysis of systemic power and inequity. Mohanty $(2003,2013)$ further critiques the ways in which the neoliberal "posteverything" has found a way to render invisible the ways in which militarism, neoliberalism, white supremacy, and heterosexism have become forms of governance and instruments for nation-building, especially in the West. Consequently, it is imperative to critically examine not only the politics of knowledge production, but its geopolitics as the uneven adoption and migration of concepts and analytical frameworks correspond to histories of colonial appropriations and misappropriations that flow across the North/South divide (Costa, 2000, 2006).

These unchecked colonial investments in academia were precisely the ones Mohanty (1986) exposed and critiqued in her essay Under Western Eyes, which targeted Western feminist scholarship. Drawing from Giroux, Mohanty $(1986,2003)$ noted that neoliberalism reduces knowledge to market logics that place all responsibility for oppression and transformation on individual empowerment and consumption, effectively dismissing the value and need for collective action and systemic analyses of structural 
oppression. Mohanty (2013), then, proposes to make conscious moves to decolonize feminist theories so that we can appropriately historicize and locate women's identities and struggles in the context of anticolonial, antiracist and anti-capitalist politics and advocacy in the era of neoliberal globalization.

Mohanty's arguments shed light on not only the causes of the trivialization and de-politization of intersectionality in the neoliberal academic and popular culture but also on intersectionality's original sin: intersectionality was engendered at the heart of the empire. The marginalized identities and emancipatory commitments of Kimberlee Crenshaw do not fully protect her or her scholarship from the pull of colonialist thought that undergirds U.S. academia. In Transnational Feminism in the United States, Leela Fernandes (2013) argues that American scholarship - critical and traditional - has successfully unmarked the U.S. as the origin of the hegemonic normative assumptions and criteria with which phenomena occurring within and outside American borders are evaluated. This way, the U.S. remains relatively invisible and stable vis-à-vis the increasingly racialized, gendered and dangerous Other. Fernandes (2013) adds that the structure of globalized communication networks ${ }^{4}$ imposes imperial regimes of visibility that focus global attention on those locations and occurrences that reinforce the cultural, moral and military domination of the U.S. and more broadly the West.

Intersectionality as a framework, indeed, does not interrogate the role that constructions of race, gender, class, sexuality, ability, etc. play in the constitution of the

\footnotetext{
4 The existence of national and international media has always been tied to the workings of political and economic power brokers (Couldry \& Curran, 2003). In recent decades, ownership concentration and media convergence have consolidated the symbolic power of Western elites worldwide, which poses complex structural challenges to activists in local contexts who try to resist neoliberal domination and violence (Fenton, 2016)
} 
nation and, more broadly, of empire. Consequently, the theory loses sight of - or renders invisible - the ways in which transnational as well as (post- and neo-) colonial geopolitics and histories shape relations of power and their mediated and material manifestations. Transnational and postcolonial perspectives are, then, necessary to enhance intersectionality's analytical and political impetus.

Patil and Purkayastha (2015) drew attention to intersectionality's transnational blind spot in their comparative study of the coverage of the rape of an Indian woman in New Delhi, India and the rape of a white woman in Steubenville, U.S., by the New York Times and the Times of India. These authors indicated that existing intersectional research contends that the experiences of rape of women of color are relatively invisible in news media compared to the experiences of rape of white women. This corresponds to racialized understandings of gender that mark women of color as sexually available and deviant, which undermines women of color's claim to victimhood and justice in rape cases (Crenshaw, 1991). Patil and Purkayastha (2015) noted that such intersectional analyses of rape had mostly been done in the U.S. context and, therefore, decided to investigate how the framework transferred to a non-U.S. setting. Their findings contradicted previous intersectional studies. While the racialized rape victim from New Delhi was hyper-visible in both papers, the white rape victim from Steubenville had barely amassed any coverage.

To understand this stark contradiction between intersectional research and empirical evidence, Patil and Purkayastha (2015) engaged transnational feminism and post-colonialism literature. Considering these theories, the authors found that the hypervisibility of rape in territories outside the U.S. resonates with orientalist narratives that 
foreground sexual violence in racialized societies to justify Western colonial domination (Tripp, 2006). By consistently exposing instances of (sexual) violence in so-called Third World countries, the empire - in this case, the U.S. - consolidates its own position as civilized and safe land. Patil and Purkayastha (2015) show, then, how intersectionality is ill-equipped to produce accurate understandings and explanations about transnational politics of representation and their role in the configuration of state power. In the following section, I present an alternative that activists and scholars have been developing since the late 1990s to enhance the political thrust of intersectionality within and out the Western world.

\section{Sharpening Intersectionality through Transversal Politics}

The limitations of intersectionality as a transnational politics beyond the West calls for the search of alternative ways to analyze and disrupt oppression without flattening difference and context. While studying the work of feminist activists in Bologna, Italy, Nira Yuval-Davis (1999) came across the concept of transversal politics.

Like intersectionality, transversal politics resists universalistic and ethnocentric politics to foreground the ways in which power distributes power and vulnerability differentially within and across social groups. Unlike intersectionality, however, transversal politics push back against the dynamics of identity politics which, with and without intersectional understandings, tend to reify boundaries between groups, collapsing individuals into collective identities and political positionalities (Yuval-Davis, 1997). Transversal politics, then, aims to shift focus from issues of political representation to make room for more flexible and politically productive solidarities. 
Yuval-Davis (1999) argues that transversal politics is founded on three principles. First, transversal politics recognize role of standpoint epistemologies in the formation of worldviews, and politics. Standpoint feminist scholars, such as Nancy Hartsock (1983) and Sandra Harding (1993), argued that meaning-making processes, including scientific knowledge production, are profoundly shaped by the systems of power and oppression that stratify societies by race, ethnicity, class, gender, and sexuality. Consequently, individuals' worldviews - and political positionings - are always already shaped by their own position, or standpoint, in the social fabric. Standpoint theory, then, renders all knowledge and positionings limited, incomplete, and historically and politically situated. By embracing standpoint epistemologies, transversal politics approaches notions of truth, belonging, authenticity and political activism not as fixed or homogeneous elements, but as the results of active dialogues and negotiations among people of different positionings (Yuval-Davis, 2006).

Second, transversal politics embrace the principle of encompassment of difference by equality (Yuval-Davis \& Werbner, 1999). The argument is that while differences are important, notions of equality should encompass differences instead of replacing them. In other words, those practicing transversal politics engage in conscious efforts to avoid flattening difference for the sake of unity or equality. However, while differences are acknowledged and respected, they do not dictate the hierarchical make-up of the group, or the way in which priorities are established. "Because transversal politics does not privilege a priori any positioning or identity, the same value system might simultaneously prioritize different political projects from different standpoints" (Yuval-Davis, 1999, p. 98). Negotiation and opportunities for parallel advocacy - that is, advocating for multiple 
causes or organizations at the same time - emerge as encouraged possibilities in transversal politics.

Third, transversal politics draws clear distinctions between positioning, identity and values. This means that in a transversal politics framework, agents do not make assumptions about or demands of others based on their social position. This way, identity, politics and values are not necessarily mutually determinant. Therefore, Yuval-Davis (2006) argues, transversal politics opens more room for diversity and intersectional politics both conceptually and politically.

Embracing transversal politics requires many re-positionings at the core of social movements. Yuval-Davis (1999) notes that from a transversal politics perspective, activists cannot and should not see themselves as representatives of their constituencies but as advocates for a cause. In this context, the very concept of leadership is destabilized to favor more service-oriented mindsets and relations. As the message, not the messengers or their status, gain more importance in transversal politics, the advocates are not required to be a member of the constituencies they support. This sense of belonging and its political possibilities, however, do not come without boundaries. Activists practicing transversal politics must constantly be reflexive and negotiate the terms of their engagement to the cause with other intersectional constituencies in their movement (Yuval-Davis, 1999). Through these dialogues, transversal activists constitute epistemological communities rooted on evolving value systems that cut across and encompass difference.

Outside an ideal-type construction of transversal politics, the real-life application of its principles does not come without tensions and risks. Patricia Hill Collins (2017), in 
her analysis of the activism of Black feminists, argues that Black women in the U.S. have consistently engaged in transversal politics to productively engage in politics. For African-American women, absolute solidarities based on race or gender were never an option as anti-woman or anti-feminist attitudes and practices tainted anti-racist movements as much as racist attitudes and practices tainted feminist movements. Consequently, Collins (2017) argues, Black feminists practiced flexible solidarities "grounded in ongoing relationships of compromise and contestation" (p. 1469). The struggle for Black women liberation, then, called for a transversal politics that allowed Black feminists to advocate for shared values and goals while challenging undemocratic and inequitable regimes of representation in both anti-racist and feminist movements. Transversal politics enabled Black feminist to remain rooted in their cause while shifting focus, activist spaces, and constituencies whenever necessary (Collins, 2017).

As Ni Una Menos engages in intersectional politics while foregrounding the heterogeneity of its constituencies and allies, it becomes necessary to examine how intersectional and transversal politics inform the collective's feminist activism. Ni Una Menos has invoked intersectionality to signal the inclusive nature of the movement. Mentions to working class, LGTBQ, rural, and indigenous constituencies usually emerge in the digital discourses of $\mathrm{Ni}$ Una Menos. Moreover, the collective has publicly established coalitions with NGOs, universities, collectives, labor unions and institutes of diverse and seemingly disparate sociopolitical positionalities and goals. All these alliances are rooted on one goal: to end violencia machista. Consequently, NUM shows attributes of transversal politics where intersectional difference is encompassed in regimes of compromise and contestation (Collins, 2017) to fight for the end of violencia 
machista in many fronts. To investigate these politics and the ways they manifest and shape the mediated activism of NUM, I advance some research questions in the following section.

\section{Research Questions}

Making sense of the mediated activism of Ni Una Menos requires delving into the historical paths of the feminist movement in Argentina and the Latin American region. As the literature has shown, the feminist collective that emerged in 2015 stood on the shoulders of established feminist organizations to articulate and promote feminist politics. Considering the diversity and at times paradoxical nature of the identities, struggles and objectives that can adopt a feminist denomination (Mohanty, 1986), it is first necessary to understand what feminist politics have been expressed and acted on within the collective Ni Una Menos. Consequently, I advance the following research questions:

RQ1: How does the collective Ni Una Menos define its own feminist politics in its online discourses?

$\mathbf{R Q 1 a}_{1}$ : How does Ni Una Menos define the grievances it acts upon in its online discourses?

RQ1b: How does Ni Una Menos construct a sense of collective identity in its online discourses?

These questions allowed me to define the type of feminist politics NUM engages in and how these politics shape the ways in which the collective grounds its political interventions and constructs a sense of collective identity among intersectional constituencies. Once the feminist politics of the collective Ni Una Menos become clearly 
defined, it is possible to examine how this politics have interacted with the mediated activism of its members. In 2015, Ni Una Menos capitalized on the positionality of its founding members. These women were mostly media and journalism workers who either formally pertained to feminist organizations, had had contact with members of the feminist movement in Argentina, or at least had some affinity with feminist politics in general. The conjunction of legacy feminists and media professionals gives $\mathrm{Ni}$ Una Menos a unique profile among social movements that traditionally have found themselves at the margins of the media system. As Friedman (2017) has demonstrated, politics and its mediations are co-constitutive as the media practices of activists are deeply influenced by their political stances while their political stances and strategies are, simultaneously, shaped by the media environments and practices they choose to use. To explore these dialectic dynamics between the media as an institution and feminism as a politics in the case of Ni Una Menos, I pose the following research questions:

$\mathbf{R Q}_{2}$ : How are media and mediated practices connected to the activism of Ni Una Menos? $\mathbf{R Q}_{2 \mathbf{a}}$ : What role did mainstream media play in the emergence of Ni Una Menos? $\mathbf{R Q}_{2 \mathbf{b}}$ : What role did mediated activism play in the political interventions of $\mathrm{Ni}$ Una Menos?

To answer these questions and get a situated understanding of Ni Una Menos, I conducted a case study in which I was able to examine and analyze various forms of pertinent data (Stake, 1995). The methodological details of this research can be found in the following chapter. 


\section{CHAPTER THREE: METHODOLOGY}

This dissertation presents a case study of the Argentine feminist collective Ni Una Menos to examine the complex relationships between the collective's mediated activism and its feminist transversal politics in the Argentine context. Ni Una Menos constitutes an instance of feminist mediated activism in the Latin American region. Considering that $\mathrm{Ni}$ Una Menos had unprecedented success in mobilizing and organizing massive collective action to support transversal feminist politics, and the prominent role of journalists and other media professionals in the constitution of the collective, this study investigates a key case (Stake, 2005). This case, therefore, provides the opportunity to critically assess the multifaceted ways in which media - digital and traditional - and media workers are implicated in the formation and transformation of societal structures and power dynamics.

In the context of this dissertation, case study constitutes a research strategy whose ultimate goal is to produce a "richly detailed, thick, and holistic elaborations and understandings of instances or variants" that shape the collective Ni Una Menos through "the triangulation of multiple methods" (Snow \& Trom, 2002, p. 152). This way, Ni Una Menos turns into the bounded system, the key case under investigation. Embracing case study as a methodological strategy, will allow me to assess this Argentine feminist collective in its real-life context using multiple methods of data collection and analysis (Thomas, 2011). George and Bennett (2005) highlight that case studies incur in a historical examination of cases because a holistic assessment of the case in its context calls for an analysis of the structural developments that shape the case as it is. Simons 
(2009) notes that case studies are defined not by a methodological choice, but by the choice of what is going to be examined. This way, case study researchers are committed to describing and evaluating the complexity of a system in its natural spatial and temporal context (Stake, 2005; Simons, 2009; Thomas, 2011). By focusing on real-world settings, examples and occurrences, case studies identify "lab-like" social formations in which the researcher can revisit existing information and theoretical propositions as well as develop new theoretical explanations based on naturalistic accounts of current phenomena (Gerring, 2007).

As Yin (2009) notes, case studies provide an opportunity to investigate contemporary phenomena that resist clear definition given state-of-the-art knowledge. Case studies are also valuable for exploratory research as they can offer insight into a case for which data are limited or faulty (Gerring, 2007). Qualitative case studies, in particular, have proven useful to examine the experiences of under-studied individuals, groups, organizations, and communities (Haas, 2004).

The case of Ni Una Menos represents, then, exploratory research into the mediated activism of a hybrid feminist organization that comprises treats of networked communities (Castells, 2015) and collectivist-democratic social movement organizations (Rothschild-Whitt, 1988) in a geographical context that is notably underrepresented in social movement and media studies scholarship. This case also provides a great opportunity to examine the involvement of professional journalists in the redefinition of their profession vis-à-vis overt feminist activism. Consequently, the case of $N i$ Una Menos would entail an instrumental case study. For Stake (1995), instrumental case studies are used to gain insights about the workings of a broader phenomenon. As this 
dissertation deals with questions about the role of mediated activism in the development and conductions of feminist politics as well as the influence of politics on the mediated practices of social movements, the case of Ni Una Menos becomes instrumental to explore intersections of media, journalism and politics.

Case studies have been useful for the development of social movement theories that connect the conduction of oppositional politics with the broader set of societal structures that facilitate and/or hinder collective action. The main propositions of resource mobilization theory and political opportunity, for instance, derive from case studies that identified the ways in which social movements and social movement organizations could capitalize on existing infrastructures - such as, communication media, financial resources, access to other institutional governmental centers, and preexisting networks - to advance their goals (McCarthy \& Zald, 1977). In fact, the field of social movement studies has mostly been constituted through case studies that investigate and compare the rise and fall of specific social movements across time (Snow \& Trom, 2002).

Considering that case studies use multiple and overlapping data sets to develop indepth and comprehensive understandings (Stake, 1995; Snow \& Trom, 2002; Yin, 2009), this study uses ethnographic data, interview data, and virtual archives and oral histories to shed light on the phenomenon under study. The collection and analysis of these data are undergirded by a commitment to feminist politics and ethics. In their book Feminist Methodology: Challenges and Choices, Caroline Ramazanoglu and Janet Holland (2002) argue that feminist scholars must engage in serious reflections and discussions about methodological choices as these are always already embedded in - potentially 
problematic - politics of knowledge production. Though definitions of feminism are historically and geographically bound, feminist approaches to research are generally characterized by "their theories of gender and power, their normative frameworks, and their notions of transformation and accountability" (Ramazanoglu \& Holland, 2002, p. 147). This way, it is not the object of the research what makes a project feminist; it is its politics, ethics and objectives.

Feminist research is explicit about the political nature and goals of its process and findings. Feminist research produces, then, theory about power imbalances to raise awareness about injustice, foster accountability procedures and finally spark the type of change that could effectively disrupt oppressive understandings as well as personal and institutional practices (Ramazanoglu \& Holland, 2002). At the end of this chapter, therefore, I offer a reflection about my positionality, motives and methodological choices in an attempt to avoid research practices that might result in the further alienation, misrepresentation, and colonization of feminist advocacy in Argentina, specifically, and the global South more broadly (Mohanty, 1984; Spivak, 1988; Anzaldua, 1989). At this point, I will describe the approach and procedures involved in the data collection process.

\section{Postcolonial and Feminist Approaches to Ethnography}

As this study revolves around questions about the media involvement in processes of meaning-making, identity and community formation, and collective action vis-à-vis feminist politics, an ethnographic approach to the mediated activities of $\mathrm{Ni}$ Una Menos becomes necessary to produce nuanced and in-depth understandings about how media traditional and new - has strengthened or challenged feminist activism in Argentina. Ethnographic work is founded on the principle that participation and first-hand 
experience are needed to produce reliable and properly contextualized knowledge. Hammersley and Atkinson (1995) indicate that producing an insightful ethnography entails exposing the researcher - overtly or covertly - to people's daily of life for an extended period of time so that she can collect "whatever data are available" that are relevant to the issues under investigation (p. 1). The idea is to "produce authentic understandings of a culture based on concepts that emerge from the study" (Hine, 2000, p. 42). This way, ethnographies are intrinsically open-ended and flexible in both their design and execution so that the researcher can adapt to the exigencies of the field (Snow \& Trom, 2002; Stake, 2005).

With the emergence of constructivism and postmodern critiques, the ability of any researcher to investigate phenomena in their natural setting and to, then, present fully authentic findings has come into question. The argument states that processes of knowledge production are always to some degree disruptive of naturally-occurring phenomena (Dezin, 1997). In the case of ethnography, the open or disguised immersion of the researcher in the research setting inevitably implies a reconfiguration of said setting and the agents that dwell in it. Furthermore, as the researcher puts together the resulting ethnographic narrative, she (re)constructs the individuals, situations, and environments that she experienced during fieldwork in light of her own evolving positionality (Berger \& Luckman, 1971). Ethnographic work, then, requires systematic reflexivity on the part of the researcher to ensure the production of properly situated knowledge (McCorkel \& Myers, 2003; Silverman, 2017).

Feminist scholars have also raised concerns about ethnography, not only in regard to the methodological challenges it poses, but about the ethics and political impact of it. 
In her article Can there be a feminist ethnography?, sociologist Judith Stacey (1988) warned that "the appearance of greater respect for and equality with research subjects afforded by feminist ethnography can mask the potential for deeper forms of exploitation" (p. 22). As researchers are inevitably in a position that always affords them a way out of the situations and spaces they study, research participants, Stacey (1988) argues, are at greater risk of betrayal, misrepresentation, and abandonment by the ethnographer. Lila Abu-Lughod (1990) echoed Stacey's warning and called for the systematic critique of projects by women of privileged backgrounds about more marginalized women, as their studies tended to universalize and romanticize a shared women's experience.

The work of postcolonial feminist scholars such as Gayatri Chakravorty Spivak, Aihwa Ong, and Chandra Talpade Mohanty allow us to extend these discussions beyond the realm of ethnographic methodology and to the field of the geopolitics of knowledge production that permeate feminist research. Spivak (1988) demonstrates that Western epistemologies, as constituted from a position of globalized hegemonic power, render those in the geopolitical periphery silenced and helpless. This way, Spivak (1988) argues, scholarship from the West furthers skewed colonial narratives about victimized nonWestern women who, because they cannot or will not attach themselves to the global capitalist process, are believed to lack agency, knowledge, and potential for progress. Ong (2001) notes that, since understandings of modernization are tied to Western commitments to free-market, industrialized economies, scholars in the West are compelled to characterize non-Western cultures and women as under-developed and oppressed. This way, Western feminist assessments of the universal oppression of Third 
World women are anchored in a hegemonic ideology that dismisses - and even vilifies alternative or native developmental goals (Ong, 2001). As these colonizing critiques are projected on the non-Western world, the normative and political interests of the imperial West remain unquestioned (Fernandes, 2015).

Mohanty (1984) focuses on the discursive or hegemonic power of the West, which has turned itself into the "primary referent in theory and praxis" (p. 334). This way, power relations and norms as defined and enforced by Western powers globally are constantly normalized and upheld in scholarship, even in feminist works that claim to disrupt and resist oppressive power imbalances (Mohanty, 1984). Mohanty (1984) specifies that there are three analytic principles within Western feminist discourse that allow it to further subordinate women in the so-called Third World. First, there is the assumption that the category "woman" is already and unproblematically constituted, implying the existence of a uniform group with homogeneous experiences of patriarchal oppression and imaginations of liberation. Second, through methodological universalism, Western feminists tend to isolate empirical data (i.e., number of veil-wearing Muslim women) from their cultural and historic context, forcing a monolithic and Western interpretation on the material realities of the research subjects (i.e., as the veil signifies oppression in the West, all veiled Muslim women are constructed as subjugated). Finally, Mohanty (1984) highlights a disproportionate focus of Western feminist scholarship on the standing of Third World women which denies the latter their status as subjects instead of objects of history. This way, Western feminist scholarship colonizes and appropriates the cultural heterogeneity of the Third World and constructs their understandings and acts of resistance as either non-existent or inconsequential. 
The critiques of postcolonial feminist scholars gain weigh as they are anchored in the acute awareness of the key role that the narratives of the 'oppressed and helpless' Third World woman have played in the legitimization of colonial rule (Said, 1978; Mani, 1998; Mihn-ha, 2000). This concern is especially prevalent among postcolonial feminist ethnographers as this methodology is mainly deployed to represent peoples and cultures at the margins of geopolitical and economic power. A postcolonial feminist approach to ethnography, then, calls for critical and reflexive practices that interrogate the researcher's philosophical and political positionality while addressing the power relations inscribed in the process of fieldwork and knowledge production (Ozkazanc-Pan, 2012; Buch \& Staller, 2014; Manning, 2016).

Speaking specifically of feminist ethnography, Richelle Schrock (2013) argues that, apart from presenting reflections about positionality, a feminist ethnographer must include in her work critical discussions about the potential benefits and pitfalls of representation, a contextualized examination of women's oppression alongside the participants' own understanding of agency and resistance, and an acknowledgement of her ethical responsibility toward the communities under study. This way, postcolonial and feminist approaches overlap to constitute ethnographic works that, through systemic reflexivity grounded in feminist and anti-colonial values, construct situated narratives that identify and represent inequality and difference while giving legitimacy to the voices and interpretations of the research subjects (Freeman \& Murdock, 2001; Schrock, 2013; Manning, 2016). Considering that this dissertation engages in the production of knowledge about a feminist collective and movement that emerged in the Third World, it is necessary for me to engage with feminist and postcolonial knowledge and politics to 
navigate the disparate power dynamics that connect me to the Argentine activists and avoid the production of colonizing narratives about Ni Una Menos.

Additionally, as these approaches pertain to the field of critical theory (Horkheimer, 1982), postcolonial feminist ethnographies are also geared toward social transformation, providing research participants in the margins with platforms for their visions of equality to be taken seriously (Foley, 2002; Foley \& Valenzuela, 2005). While the members of the collective Ni Una Menos cannot be characterized as passive subalterns by any stretch of the imagination, it is important to define the ways in which this research impacts their activism in Argentina. As these activists have voice and goals of their own, it is necessary to situate this research as a collaborative project from which not only I as a researcher will benefit (Kapoor, 2016). Adhering to feminist and postcolonial approaches to research, in this dissertation I work with the research participants to produce knowledge that contributes to the empowerment of feminist advocacy in Argentina and the expansion of literature that foregrounds Latin American understandings and activism. Research participants will have access to the transcripts of their interviews, and the ethnographic narratives that emerge from my research. Additionally, if they choose to, research participants will be given a space to respond to my findings. Their responses will be part of the findings section of this dissertation. This work is, then, a political act inscribed in feminist struggles in Argentina, the Latin American region, and their links to the political, economic and hegemonic power of the West. 


\section{Ethnographic Fieldwork in Digital Spaces}

The ethnographic work in this dissertation takes a distinctive shape as it mostly takes place in digital instead of physical settings. Hine (2000) has argued that digital spaces are characterized by their lack of clearly identifiable temporal and spatial boundaries. While geographic locations were key for early anthropologists and ethnographers to identify the communities they would work with, the apparently disembodied nature of the internet poses an ontological challenge for researchers: How do we conceptualize the field site in an online environment? (Hine, 2015).

Debates about the nature of the field site are, however, not new or caused by the emergence of digital spaces. Gupta and Ferguson (1997) noted that the definition of field site had traditionally been taken for granted in anthropology, an academic field driven mostly by ethnographic methodology. They argued that geographically bounded notions of field sites had become so entrenched in anthropology that researchers virtually constructed their identities not around the object of their research but the location of those objects (Gupta \& Ferguson, 1997). Such geographic fixation posed a challenge when defining and studying transnational phenomena. Marcus (1995) resisted the idea of static field sites by encouraging anthropologists to select objects of study characterized by movement and trans-geographic elements, such as conflicts or even metaphors. This way, Marcus (1995) argued for the value of multi-sited ethnographies as means to better explain contemporary life, as it is characterized by connectivity and mobility rather than static locations. Taking this argument further, Amit (1999) proposed understanding the field site as an artful construction instead of pre-existing location. This move allowed for the recognition and discussion of the role of the researcher in constituting her sites of 
study and set a clearer path for exploring sites that are not defined by spatial bounds (Amit, 1999).

In the field of sociology, the notion of mobility was the one that sparked calls for new ethnographic methodologies. Buscher and Urry (2009) advocated for the adoption of mobile methods to examine the movement of things, people and ideas as a constitutive force of communities and, more broadly, societies. Buscher and Urry (2009) did not limit their understanding of mobility to bodily or physical movement; mediated communications and interactions were also part of the mobilities of human experience, politics, and culture that would fall under examination. This way, mobility was "as much a sensory experience as it [was] a practical effect of taking a thing elsewhere" (Hine, 2015, p. 63). These developments in anthropology and sociology, Hine (2015) argues, were key for the development of ethnographic work in the Internet, as the field sites could effectively be conceptualized as mobile and multi-sited.

As ethnographers turned their attention to the Internet, they quickly realized that they were dealing with complex sites whose boundaries were hard - or impossible - to pin down. While studying the online practices of teenagers, Leander and McKim (2003) concluded that online and offline identities and practices were mutually elaborative, as they had to shift focus between online and offline practices to make sense of the participants' modes of engagement. Aouragh (2011) also had to effectively explore online and offline spaces in her ethnographic study of Palestinian local and global political mobilization.

Multi-sited and mobile ethnographies that dealt with the impact of the Internet on social life led to complex understandings of the entanglements that connect material 
realities and histories to the nature and uses of technology. In her examination of the impact of the internet in feminist and queer activism in Latin America, Friedman (2017) argued that as the uses and impact of the internet are shaped by historically variable social contexts, the transformative potential of the internet is linked to the consciousness and creativity of the activists who use it. By studying the relationships between individuals - who are invariably shaped by their positions in gender, race, class, sexual, and other hierarchies - and technology, Friedman (2017) calls for a re-centering of the analysis of pre-existing social environments to understand why and how communities engage with and through technology (Friedman, 2017).

I am inspired by a sociomaterial approach called "information ecology analysis," as conceptualized by Bonnie Nardi and Vicki O'Day ... Its central insight is to show that the values of social communities inform technological practices, rather than practices emerging from static technological attributes that somehow inevitably guide users to a predetermined end (Friedman, 2017, p. 17).

As Friedman (2017) also incorporated feminist and postcolonial methodologies and ethics to her work, she pushed for methodologies that foreground the experiences of women and non-binary people and are sensible to the power dynamics that structure and connect social life both online and offline. As this dissertation engages with questions about the digital media practices of Ni Una Menos activists and the role digital media had in the collective's constitution and advocacy, I adopt Friedman's (2017) postcolonial feminist sociomaterial approach to this virtual ethnography. Consequently, this work is multi-sited and focuses on the physical and virtual mobilities of bodies, ideas and politics. Practically, this means that I explore the practices, discourses, and interactions of members of Ni Una Menos in their online and offline spaces to address the entanglements between their material realities and their engagement with certain communication technologies. 
Paradoxically, in the case of this dissertation, it was only using communication technologies that I could have some access to the offline experiences of the research participants. Coming into this project, my own mobility was compromised, which made a fieldwork trip to Argentina impossible - I explain these circumstances in detail in the researcher positionality section of this chapter. Therefore, it was exclusively via digital communication technologies that I had "face-to-face" access to the research participants.

At this point it is important to remember that, especially in virtual ethnographies, "fieldwork entails following connections whilst reflecting on the circumstances and actors that bring these connections to being" (Hine, 2015, p. 69). The field of this research was constituted and negotiated dynamically in a span of two years and with different levels of knowledge and engagement by the members of Ni Una Menos. Before setting on the topic of this dissertation, I spent time following the official Twitter and Facebook accounts of Ni Una Menos and some of its members. I started following these accounts around February 2017, when I did my first research project about Ni Una Menos exploring how the collective used Twitter to recruit, mobilize, and motivate people to engage in feminist political action. As I continued following the social media interactions of the collective, I came across the website LatFem.org, whose editorial board is made up by members of Ni Una Menos and offers feminist journalistic coverage of an array of issues in Argentina, such as the legalization of abortion, the national budget, and femicide. On spring 2018, I conducted another study about this website to critically examine how these journalists and activists were defining and practicing feminist journalism in Argentina. Because of the methodological characteristics of these studies they were discourse analyses - and the nature of the research sites - public Twitter 
accounts and websites -, I was able to "lurk" online to observe the practices of the collective without their knowledge. Once I decided to fully engage in ethnographic work for the dissertation, I had to come out of the online shadows to openly negotiate access to members of Ni Una Menos through video-conference applications. As Hine (2015) noted, these mediated interactions were instrumental for me to learn to navigate the sociomaterial realities of $\mathrm{Ni}$ Una Menos and obtain rich naturalistic data. This array of online spaces was, then, functioning as a source of data, a site for observation, and a means to communicate with research participants. It is important to note, however, that the physical separation between me and the research participants and offline sites render the observations of the virtual ethnography inevitably partial (Hine, 2000).

To find the most meaningful data about the online and offline life of $\mathrm{Ni}$ Una Menos, I had to determine which online spaces carried the most weight in processes of community building, meaning-making, and mobilization for the collective (Hine, 2000, 2015; Kozinets, 2010). Internet research pioneer Howard Rheingold (1993) defined virtual communities as "social aggregations that emerge from the net when enough people carry on... public discussions long enough, with sufficient human feeling, to form webs of personal relationships in cyberspace" (p. 3). This concept concentrates the attention of researchers on the collective nature of online communities and the centrality of communication in online community building. Furthermore, it foregrounds the fact that online communities are not "fixed in form or function," as meanings, identities and goals are constantly negotiated by individuals in "the context of external constraints" (Komito, 1998, p. 105). This way, the affective and strategic connections that emerge online respond to material - offline - realities. 
To successfully identify virtual communities, Kozinets (2010) notes that some sense of permanence or repeat contact is key for notions of belonging in online spaces. Ritualistic social interaction in the form of online dialogues engenders subjectivities among the members of online communities that allow individuals to construct themselves and others as members of certain groups. While a continuum of participation exists meaning that not all members of online communities engage to the same degree -, "repeat contact, reciprocal familiarity, shared knowledge of some rituals and customs, some sense of obligation, and participation" are instrumental to become part of an online community (Kozinets, 2010, p. 10). The members of the group are the ones who determine the degrees of interaction and identification that are required to become effectively included in and represented by and online community. Therefore, in this dissertation, I define Ni Una Menos online communities in the terms of its own members.

As a I was conducting studies about Ni Una Menos, I could engage with the official websites and social media accounts of Ni Una Menos, namely niunamenos.com.ar, the Facebook group Ni Una Menos, and the Twitter accounts @NiUnaMenos_and @ColectivoNUM. I also identified, followed, and interacted with leading figures of the movement, such as Ingrid Beck, Agustina Paz Frontera, Valeria Sampedro, and Cecilia Palmeiro, through Twitter and Facebook. In-depth interviews later provided further insight and context about the role and significance of each platform in the activities of the collective. As I immersed myself in Ni Una Menos' online communities, I took "reflective fieldnotes" to record my learning of the "languages, rituals, and practices," and my "involvement in a social web of meanings and personalities" (Kozinets, 2010, p. 114). This reflexive dimension is key to keep track of 
the conditions and contingencies - and frustrations - that brought about certain research strategies and, thus, the bodies of data that ground the final ethnographic narrative in this dissertation (Finlay, 2002; Hine, 2015). The following section delves into some of the reflections I engaged in before and during this study.

\section{Researcher Positionality}

My interest and stance on research about Ni Una Menos are deeply rooted in my early experiences with critical and feminist scholarship, the formation of my feminist politics, and my position as a Venezuelan immigrant living and studying in the United States. My involvement with Ni Una Menos, then, is intertwined with my experiences with gendered and racialized systems of power which have shaped my life and my politics as an immigrant woman of color in American academia.

Ni Una Menos and the feminist movement in Argentina came into my radar when I saw a Facebook post that an acquaintance of mine shared in the early spring of 2017 . I cannot remember specifically what the post read, but it stated opposition to Ni Una Menos by noting that the lives of men were as valuable and endangered as the lives of women. The fact that a feminist movement in Argentina was being "all-lives-mattered" captured my interest. I did some searching and became impressed by the collective's victories in Argentina and its transnational reach. I was specially inspired by the fact that female journalists had been instrumental to spark the whole movement. How wouldn't I? I am a journalist.

Ni Una Menos also stuck with me because I was going through a transformative period of my academic development. During the 2017 spring semester, I was taking my first feminism class in the Women's and Gender Studies department at the University of 
Missouri. The readings and class discussions sensitized me to transnational issues of gender and race, and I was quickly and willingly marrying the emancipatory goals of critical scholarship. As I was going through my own feminist awakening, reading about Ni Una Menos empowered me. My adviser recommended me to keep an eye on Ni Una Menos. Two years later, the collective is the core of my dissertation.

The original plan for this dissertation involved travelling to Argentina to conduct immersive fieldwork. However, contingencies in both Venezuela and the United States effectively undermined my mobility.

The first set of problems came from Venezuela. My passport was about to expire, and the Venezuelan Administrative Services of Identification, Migration and Foreign Citizen Affairs (Saime for its Spanish acronym) was not responding to my requests for passport renewal. Only people paying Saime officials "on the side" and in American dollars could have their passport renewal expedited. At the time, people were paying around \$1,000 dollars per passport. Neither I or my family had that kind of money.

Then I encountered a second set of problems, embodied in the Trump administration's approach to immigration. Since I hadn't gone out of the U.S. since I came to pursue my master's back in 2014, my F-1 visa had expired. To come back to the U.S., I would need to renew my student visa. While I was making inquiries about this process in the International Center at Mizzou, the staff warned me that students had been having issues renewing their visas ever since Donald Trump became president. They indicated that F-1 visa renewals that would have gone through easily in the past, were now being denied for no reason. Considering the conflictive relationship between the 
U.S. and Venezuela, the strange situation with my passport and Trump's immigration policy, I decided not to travel.

In very real ways, then, state and immigration politics have impacted my mobility and, thus, my academic work. As I am engaging with transnational and postcolonial approaches to a case developing outside the U.S. and the West, my limited mobility compromises my ability to assess the day-to-day activities of members of the collective Ni Una Menos and the material realities they must navigate. These circumstances threat to make my work dependent on skewed "regimes of visibility" that could render invisible not only the material realities research participants face and the material consequences of the research process, but the existence and importance of other relevant individuals and experiences (Fernandes, 2015, p. 108). The members of the collective Ni Una Menos are professional middle-class women enacting and embodying sophisticated feminist politics. Therefore, I need to be aware of the privileges its members are capitalizing on to advance specific feminist agendas.

As important as it is to amplify the voices and causes of non-Western individuals (and Ni Una Menos is in this category), it must also be acknowledged that the socioeconomic position of these activists makes it harder to dismiss their agency and their construction of women's grievances in Argentina. In other words, I am dealing with oppressed yet relatively powerful individuals in Argentine society who have been able to navigate and sometimes intervene institutions, such as the state, NGOs, and journalism, as well as to maximize the benefits from using new communication technologies. Their relative power makes them more visible in the international stage and to me as a 
researcher. However, their experience should not be universalized as an Argentine or even Latin American experience.

In another note, Fernandes (2015) also argues that transnational scholarship deployed from the West traditionally leaves the researcher's position and the geopolitics of her methods and knowledge unquestioned. Therefore, in the reflective practices I incorporate throughout this dissertation, I constantly interrogate the Western origins of my graduate education and foreground the Venezuelan roots of pretty much the rest of my human experience. I am intentionally specific about my nationality here because I have found it to be a good anchor for nuanced analysis and postcolonial awareness.

I do not fully identify with U.S. sanctioned understandings of Latinidad. Research has found that the Latin American identity has been mostly a product of U.S. marketing, pop culture, and census (Mendible, 2007; Valdivia, 2008). This has allowed me to make sense of me never identifying or being identified as Latina before filling out my visa application to come to the United States. My experience is marked by my Venezuelan origin and my upbringing as light-skinned cis gender middle-class woman. My connection to Latin America was merely a geographic one - I was obviously aware that Venezuela was in the Latin American region and that positioned me in a distinct international grouping. However, considering that the political, economic, social, and cultural diversity within and across Latin American nation-states is so great, I never laid claim on Latinidad or a "Latin American experience." I strongly believe that such unifying experience does not exist in the sub-continent, even though most Latin American countries do share histories of colonialism and, as a result, a common language. 
Furthermore, when I was living in Venezuela, the term Latino made me immediately think of peoples inhabiting an entirely different geopolitical space: The United States. Consistent with findings in Latin American studies, my experience has taught me that Latinidad as identity and lived experience only emerges when confronted with American politics and anxieties about race, citizenship, immigration, and nationhood (Mendible, 2010; Rincon, 2017). Therefore, it is necessary to be reflexive about our transnational solidarities. As some categories of identity, such as Latinidad, emerge from historic patterns of colonialism and racism, it might be necessary to find other anchors for political coalition.

Being aware of these geopolitics is instrumental to ground the epistemology, ontology and axiology of this dissertation. I am here informed by the constructivist paradigm whose epistemological and ontological stance recognizes that knowledge is a compilation of human understandings that are invariably shaped by historical, geopolitical, material, and cultural arrangements. As critical theories also guide my work, I openly engage in axiological work, meaning that I provide normative assessments about the legitimacy of such societal arrangements.

\section{Semi-Structured In-Depth Interviews}

As the ethnographic narratives in this dissertation have been defined from the onset as the result of collaborative work with the research participants, the collection of interview data is of key importance. Specifically, I conducted semi-structured interviews, meaning that apart from following a pre-determined interview guide, I had the chance "to digress and to probe" along with the research participants during the interview (Blee \& Taylor, 2002, p. 92). Furthermore, this open-ended interview technique allows 
participants to "generate, challenge, clarify, elaborate or recontextualize" understandings of their own motivations and actions in the context of their feminist activism.

Semi-structured interviews have been found to be particularly useful in social movement studies as they add depth and breadth to research that explores the complex social events, histories and motivations that surround social movements (Blee, 2001). Additionally, semi-structured interviews are effective at complementing other methods such as participant observation and document analysis as they allow research participants to communicate their own ideas, thoughts and experiences in their own words, guiding the researcher through their own meaning-making processes (Denzin, 1989; Staggenborg, 1991; Jenness \& Broad, 1997). Gaining access to the activists' worldview is key to reconstruct their movements, as these worldviews are often successfully pushed to the margins or misconstrued by the dominant culture and institutions the activists target (Ryan, 1991).

Through semi-structured interviewing, researchers can gain insight into the individual and collective visions, imaginings, hopes, expectations, critiques of the present, and projections of the future on which the possibility of collective action rests and through which social movements form, endure, or disband (Blee \& Taylor, 2002, p. 95).

In the case of Ni Una Menos, semi-structured interviews are key to get to the activists' own understandings of their own social world and lived-experiences, as these understandings are seldom articulated in American and English-language scholarship (Molyneux, 2001; Friedman, 2017; Waisbord, 2018). Moreover, the history of feminisms in Latin America is marked by transnational processes, such as neoliberal globalization and violence, and cross-national alliances that are unique to this region (Friedman, 2017). Therefore, to achieve authentic ethnographic narratives (Ramazanoglu \& Holland, 2002), 
it is necessary to give priority to the voices of those who embody and carry the feminist struggles in these contexts.

To identify potential participants, I took note of the Argentine activists that author Paula Rodríguez interviewed for her book Ni Una Menos (2015). The list included 24 members of the collective. Then, I searched these activists on social media - mainly Facebook and Twitter - and sent them a request to participate in my study through the private message features of each platform. The request described my study and its goals and indicated the voluntary nature of their collaboration.

When these attempts were unsuccessful, I contacted professor Carolina Escudero, who is the University of Missouri's liaison with the Barcelona study abroad program. Dr. Escudero happens to be Argentine and acquainted with many of the Ni Una Menos activists. She provided me with the personal emails and phone numbers of 12 members of the collective, to which I sent participation requests. Only three activists responded to these communications, namely Marcela Ojeda, Hinde Pomeraniec, and Florencia Abbate. Marcela Ojeda is a reporter for Radio Continental and she was part of Ni Una Menos in its seminal moments in 2015. Ojeda is no longer part of the collective, but she keeps supporting it from the sidelines. Pomeraniec is journalist and columnist for newspaper $L a$ Nación and she is also a former member of NUM. Abbate is a sociologist and researcher for the NGO Conicet, a government agency which co-ordinates most of the scientific and technical research done in Argentine universities and institutes.

My fourth interview came about a bit differently. Marcela Ojeda encouraged me to contact the regional chapters of Ni Una Menos, as she noticed that, so far, I had only been exposed to the work and online discourses of Ni Una Menos Buenos Aires. I used 
Facebook Messenger to send participation requests to Ni Una Menos Córdoba, Mendoza, Tucumán, and Santa Fe. Only Agustina Vilte of Ni Una Menos Tucumán replied to my message and agreed to do the interview. Vilte is a junior student of archeology and she has been advocating on behalf of Ni Una Menos and the National Campaign for the Right of Legal, Safe and Free Abortion for approximately three years.

These interviews were conducted via Skype, Google Hangouts and WhatsApp video conference, and had an average duration of 58 minutes. Follow up questions were dealt with through instant message services, and the participants had access to the transcripts of our conversations.

\section{Critical Discourse Analysis}

To complement the ethnographic and interview data, I have conducted a critical discourse analysis (CDA) of an array of online discourses by members of Ni Una Menos. The online data was collected from Ni Una Menos' official website, niunamenos.com.ar, as well as its official accounts on Facebook and Twitter. I analyzed the Facebook posts of Ni Una Menos Tucumán because of my access to Agustina Vilte. I have also included data from the Twitter accounts of recognized members of the collective. For this dissertation, I collected data from these sources between May 11, 2015 - when Marcela Ojeda sent the tweet that sparked the first Ni Una Menos mobilization - and December 31, 2018. In total, I collected 259 Facebook posts and 535 Twitter posts. However, I analyzed these texts to the point of data saturation, taking into consideration the source of the data, and relevant moments and milestones for the collective, such as the annual demonstrations on June 3 and March 8 and the publication of the Report on Violencia 
Machista on November 2016. Therefore, this dissertation shows the analysis of 118 Facebook posts and 226 tweets.

Apart from the online discourses and social media interactions, I also critically analyze a piece of oral history about the collective written by Argentine writer Paula Rodríguez (2015). The e-book Ni Una Menos (Rodríguez, 2015) is a compilation of testimonies by members of the collective, Argentine NGO workers, and relatives of femicide victims that retraces the collective to its inception in the aftermath of Chiara Páez death. The e-book juxtaposes testimonies about the rise and development of $\mathrm{Ni}$ Una Menos as a feminist collective in a chronological manner, providing insights about the motives and tensions that undergirded the history of Ni Una Menos. I got access to the ebook Ni Una Menos while I was at the online "lurking" stage of my research in early 2018 (Hine, 2015). Some members of the collective had tweeted about the book in and I followed the trails to these sites for virtual fieldwork.

The application of critical discourse analysis to these discourses is essential to effectively understand them as situated social practices that simultaneously communicate and influence the social, historic and cultural schemas that inform people's understandings and reactions of reality (Wodak, 2008). This way, discourse becomes the product of dialectic processes in which individuals, institutions, ideologies, history and many other factors work together to produce a unique form of text which, once uttered and/or distributed, influences the same social and structural factors that shaped it in the first place (Wodak \& Meyer, 2009). Fairclough and Wodak (1997) outline the social role and significance of discourse as follows:

Discourse is socially constitutive as well as socially conditioned - it constitutes situations, objects of knowledge and the social identities of and relationships 
between people and groups of people. It is constitutive both in the sense that it helps to sustain and reproduce the social status quo, and in the sense that it contributes to transforming it (p. 258).

This notion of discourse emphasizes the complex ways in which language use is connected to its context. Therefore, to analyze discourse and assess its long-reaching implications, researchers ought to make visible the relationships between context and discourse, weighing how language use constitutes, expresses and legitimizes phenomena such as power, domination, discrimination and identity formation (Wodak, 2008). In other words, the focus when conducting a CDA is on the role of discourse in the "(re)production and challenge of social dominance" (van Dijk, 1993, p. 249). This way, critical discourse analysists do concern themselves with the relations between discursive practices and problematic power structures in society (Wodak, 2009).

Despite the significant ways in which CDA situates discourse in context, this methodology has been virtually neglected in new media research so far (Fuchs, 2017). KhosraviNik (2013) has noted that "critical discourse analysis appears to have shied away from new media research" (p. 292). Fuchs (2017) also laments the almost exclusive focus on quantitative, de-contextualized and apolitical methodologies to study social media and has called for the application of critical theory and methods to the study of the internet. The goal of a critical move in Internet and social media studies, for Fuchs (2017), entails "the study of how ideologies are expressed on social media in light of society's power structures and contradictions that form the texts' contexts" (p. 44). As I link ethnographic and interview data to a longitudinal critical analysis of the discourses produced by Ni Una Menos and its members, I search to produce the type of situated and politically-conscious understandings that Fuchs (2017) and others have requested. 
It is important to note that even CDA has been object of criticism for having gender as a blind spot. Although many CDA studies have examined gender representations in discourse (e.g., Baxter, 2003; Wodak, 1997; Hall \& Bucholtz, 1995), they have not explicitly drawn from feminist theories and sensibilities, which would give these scholars a stronger ground to challenge gendered systems of oppression and advance emancipatory goals (Lazar, 2007). A feminist approach to CDA, Michelle Lazar (2007) has argued, would not only sharpen the method's tools to identify gender-based inequalities transpiring from discourse; it would enhance scholars' ability to advocate for social justice. As this dissertation is deeply informed by feminist and postcolonial theory and ethics, I let those commitments permeate my reading and analysis of the discourses of Ni Una Menos to engage in a thorough - and political - discussion on gender that demystifies transnational relations and structures of power.

\section{Data Analysis}

This dissertation, as most case studies, has not followed a straight line from the formulation of research questions, to data collection, to data analysis. As Stake (1995) indicates when discussing the data analysis stage in case studies, "there [was] no particular moment when data analysis [begun]" (p. 71). Even though there is not a clear starting point for data analysis in this study, I carried out iterative patterns of analysis as different sets of data (i.e., interview transcripts) started to become available to me and I could compare them to previously obtained and analyzed sets of data (i.e., the social media data, and reflective notes from the field). The analysis, as Stake (1995) describes, has entailed pulling the data apart and re-assembling its key elements into a meaningful narrative that captures the nature of the case. Following Stake (1995), I recognize that 
despite the careful design and collection of data, much "intuitive processing" went into the search of patterns and meaning in the rise and constitution of Ni Una Menos (p. 72).

As this case study constitutes an intrinsic case, the primary objective in the data analysis is to understand the case by teasing out relationships, probing issues, aggregating categories, and recognizing patterns (Stake, 1995). The idea is to generate a naturalistic account of the case that describes and contextualizes the processes and patterns identified in the environment of the case that can illuminate the functioning of the case as a bounded system. In the analysis, these patterns and processes are identified and put into categories or themes that can be understood individually and as a whole (Creswell, 2012). A naturalistic approach also allows room for researchers to incorporate their own interpretations and perspectives and ultimately construct a clearer and collaborative understanding of reality (Stake, 1995).

I started the analysis by engaging in open coding of the data, including reflective field notes, online content from $\mathrm{Ni}$ Una Menos social media and websites, the $\mathrm{Ni}$ Una Menos e-book, and interview transcripts. During open coding, I assessed in vivo discourses by and supplied by the research participants to identify first-order constructs as reflected through open codes and index words (Stewart, 1998; Swanborn, 2010). Then, I applied axial coding to recontextualize, refocus, prioritize and cluster first-order codes into themes (Swanborn, 2010).

As I construct the narrative about this case, I acknowledge the ways in which my subjectivities shape my representation of the realities of $\mathrm{Ni}$ Una Menos. The goal is to emphasize participants' experiences and meaning-making processes in reference to their social reality as they live it (Hamel, Dufour \& Fortin, 1993). In words of Manning 
(2016): "I need to ensure I am not speaking for the women, but speaking with them" ( $p$. 94). The findings of this study are, then, presented applying Haas' (2004) reflective case report framework, in which the researcher's voice and positionality are explicit throughout the narrative. The report includes particular descriptions, which comprise quotes from interviews, field notes, and social media as well as general descriptions, which explain whether the quotes are typical of the data set as a whole (Erickson, 1986). These descriptions are accompanied by interpretive commentary, which provide a framework for understanding both forms of description (Haas, 2004). 


\section{CHAPTER FOUR: THE TRANSVERSAL POLITICS OF NI UNA MENOS}

To understand the activism of $\mathrm{Ni}$ Una Menos it is necessary to know not only its stated objectives but the politics the collective has pursued over time. It only takes a glimpse at $\mathrm{Ni}$ Una Menos' mediated discourses to understand that the collective grounds its activism on feminist politics. The charter of Ni Una Menos, posted in the collective's website, indicates that the collective "assembles an array of feminist wills" to "transform our mourning into possibility" and to "do politics" (“Charter," n.d., para. 4). Despite NUM being this straightforward about its politics, it is necessary to examine exactly what they mean by feminism and how that translates into their activism, goals, and sense of collective identity.

The first research question of this dissertation addresses the need to unpack the collective's politics by explicitly asking how Ni Una Menos defines its own feminism in online discourses. To answer this question, this chapter is divided into three sections. The first describes how the collective defines the grievances that mobilize its constituencies in its online discourses $\left(\mathrm{RQ}_{1 \mathrm{a}}\right)$; the second examines the construction of a collective identity in the online discourses $N i$ Una Menos $\left(\mathrm{RQ}_{1 \mathrm{~b}}\right)$; and, lastly, the third section presents the discussion of these findings, synthesizing these components to describe and comprehend Ni Una Menos' conceptualizations and praxis of feminism. The chapter is, then, mostly concerned with the politics of the collective as they define them in its digital spaces. Specifically, I explore the way NUM defines issues, itself and the constituencies it advocates for as well as how these foundational understandings inform the collective's goals and practices as part of the feminist movement in Argentina. 
It is worth noting at this point that the power dynamics involving the media as an institution and as a space and tool for activism are in no way dismissible when speaking of the politics of Ni Una Menos. The findings of this case study, taken as a whole, do support Friedman's (2017) argument that communication technologies and mediated practices are "constitutively entangled" with the material realities and politics of the communities who use them (p. 5). However, I have isolated the discussion of such dynamics with media and mediated activism to the next chapter of this dissertation, where I answer the second research question. This separation between politics and its mediated facets is, therefore, artificial and responds to the need for analytical clarity, not to a clear-cut distinction emerging from the data.

The findings I present here show how broad, yet focused feminist commitments have allowed Ni Una Menos to engage in transversal politics (Yuval-Davis, 1999). Via transversal politics, NUM remains rooted in its struggle against violencia machista, while practicing flexible solidarities (Collins, 2017). This way, the collective is able to shift focus to acknowledge and advocate for instersectional constituencies in multifaceted arenas without severely compromising the members' sense of belonging. The case of $\mathrm{Ni}$ Una Menos, then, provides the opportunity to rethink approaches to identity politics in the context of feminist social movements as the incorporation of transversal politics opens new paths for the productive embrace of intersectionality in feminist politics.

\section{Violencia Machista at the Core of Feminist Interventions}

Since its inception, Ni Una Menos has been a political response to and rejection of loss. The very name of the collective manifests an affective refusal to loss: ni una menos, not one woman less. As indicated in previous chapters, Ni Una Menos first emerged as a 
series of public events sponsored by the National Library to mourn victims of rape and femicide. Then, the name was picked up in Twitter to stand for the outrage of many Argentines reacting to the murder of Chiara Páez, 14. "They are killing us!” tweeted journalist Marcela Ojeda on May 11, 2015, when Chiara's body was found, signaling not only the loss of yet another girl, but the pervasiveness of the loss of women, and the precariousness of female life in Argentina. Three weeks later, Ni Una Menos held its first massive demonstrations in multiple Argentine cities.

In the months before Chiara's death, public awareness of violence against women was increasing. The NGO La Casa del Encuentro had published in January 2015 a report that indicated that 1,808 women had been murdered in a seven-year period, with 277 women assassinated just in 2014. To provide a space for relatives of the victims and activists to express grief, the National Library along with feminist organizations created a reading series called Ni Una Menos. In one of such meetings, journalist Marina Moreno read her text "Mujeres de la Bolsa," in English "Women of the Trash Bag." The text discussed the historical and political significance behind the fact that many of the murdered women were being disposed of in trash bags. In a Facebook post of the group Ni Una Menos Argentina (https://www.facebook.com/NUMArgentina), "Women of the Trash Bag" is deemed a foundational text for NUM. Some of it reads as follows:

There is a political history of the bag. If the bag was a mythical mess of cosmetics, it stopped being so when it started hiding revolutionary weapons: militant pamphlets, notebooks, books and blueprints; the bag becomes bigger and functional.

What about the trash bag? Taking a trash bag out implies expelling out of the home the waste of productive life. When industrial trash bags appeared, the object transitioned from the space feminism called the site of invisible labor to the workplace of the building manager. The toolbox of the assassin today includes the trash bag and the trash container, the sewer and the blind swamp were pragmatic 
reason reveals a semiotic horror: women are trash (M. Moreno as cited in NUMArgentina, 2016, March 26).

The text clearly constructs the bag as a site of historical feminist struggle. Moreno uses the contents of the bag as material testimonies of the feminist movement in Argentina, which saw women's consciousness shift as they transitioned from the home to the education system and then to the labor force. References to pamphlets connect this text with part of the repertoire of collective action of popular feminist collectives, such as Unión Feminista Argentina (UFA), Movimiento de Liberación Feminista (MLF), Movimiento Feminista Popular (MOFEP), and Frente de Izquierda Popular (FIP), who in the 1970s conducted volanteadas to distribute feminist and pro-union pamphlets on the streets. The very nature of the event in which "Mujeres de la Bolsa" was read can be understood as a nod to the legacy of feminist collectives in the 1970s and 1980s because the organization of reading marathons and conferences was common practice in their efforts for consciousness raising.

Now, as Moreno shows, the trash bag and its new contents, women's dead bodies, deliver new messages to and about the feminist movement. The trash bag reminds women that they live in an anti-feminist world, a world that punishes and disposes of women who have transcended the home and rendered themselves and their labor visible. This characterization of femicide and its causes, however, has been at the core of feminist theorizations for decades in Latin America. Feminists in Argentina had been thinking of femicide and rape as pedagogical acts men perform to show not only the victim but all women that the exercise of their autonomy can be read as rebellious and, therefore, publicly punishable. In the words of Argentine sociologist and member of Ni Una Menos, María Pía López: 
There is something there that looks like a warning. A girl goes out to dance dressed however she wants to, has sexual relations with whomever she wants to, or leaves her partner to pursue another life path. In a lot of cases, these [behaviors] appear as triggers of crimes. In that sense, I think that much of what happens appears as a punishment against the freedoms acquired. There is more economic autonomy, more social autonomy, and a more violent response from those who cannot control [women] anymore. Lots of crimes happen when the woman abandons, says no, or can prosecute (as cited in Rodríguez, 2015).

The pedagogical role of violence is here foregrounded and deconstructed. López hints at the histories and traditions that have granted men control over women's bodies and points at the anxieties that emerge about losing such control. Then, she places this power and anxieties at the core of instances of violence against women. As feminists and activists delve into the nature and origins of violence against women, a need for specificity seems to emerge. In their communications and activism, members of Ni Una Menos have insisted on departing from terms such as domestic violence, crimes of passion and even violence against women to describe women's oppression and vulnerability in Argentina. Instead, they have pushed for the popularization of the term violencia machista.

This move goes beyond mere semantics. The turn to violencia machista yields a broad array of meanings within the feminist movement and Ni Una Menos that opened, I argue, more possibilities for collective and intersectional action. This is important to note as the origins of Ni Una Menos - a social media campaign in response to a femicide might tempt the casual observer to characterize the collective's activism as merely reactive. However, once the collective was formed a week after Marcela Ojeda sent out her tweet, NUM members shifted the attention quickly from grief to plural grievances that encompassed multiple fault lines in Argentine culture, human rights protections, the economy, the justice system, and state politics. 
Through its social media and overall digital presence, then, Ni Una Menos engaged in what Florencia Abbate, member of NUM, calls "conscientization efforts" alongside "mobilization efforts" (F. Abbate, personal communication, May 5, 2019). A key part of the conscientization effort, Abbate indicates, was to provide language and a clear understanding to the population about the diverse circumstances that are conducive to femicide and rape. Despite scandalous levels of violence were still in focus, $\mathrm{Ni}$ Una Menos worked to move public debate beyond horror and grief and into a framework that renders visible the contributing factors that made widespread femicide and rape possible in Argentina. In a document put together by members of $\mathrm{Ni}$ Una Menos that was read at the June 3, 2015 demonstration in Buenos Aires, it reads:

We need to add wills to change a culture that tends to think of woman as an object for consumption and disposal instead of an autonomous person. Femicide is the most extreme form of that violence and it cuts through all social classes, religious beliefs and ideologies. But the word femicide is, moreover, a political category, it is the word that denounces the way in which society naturalizes something that is not natural: la violencia machista (NUM, June 3, 2015).

The political thrust of the collective becomes unequivocal in this first manifesto. The document engages trademark feminist understandings of female objectification and connects them to the main argument Moreno advanced in her "Women of the Trash Bag:" that women have been constructed as objects and, thus, become disposable. Femicide, then, is understood as an extreme manifestation of a very specific type of violence that does not discriminate when it comes to reclaiming victims. The text communicates this by noting that women of "all social classes, religious beliefs and ideologies" can be affected. This particular utterance foreshadows the collective's broadening constructions of violencia machista, which engage discussions about the economic, religious and political factors that inform society's understandings of and 
responses to this type of violence. As the first Ni Una Menos demonstrations were in the works in May 2015, it seems that diverse factions of the public seized the opportunity to expand the conversation from femicide to violencia machista to achieve a larger impact.

Very soon we could see that this was not just a reactive chain; this was something else: There was someone listening on the other side, talking about this 500-yearold issue that had never become amplified this way. In places where the topic [of violencia machista] usually did not come up, the terms "violencia machista" suddenly appeared... The recurrence of [femicide and rape] cases that had some social impact joined the years of conscientization and social pedagogy coming from a thousand places... Given these conditions, a cascade of knowledge, practices, and preexisting ideas could combine (Soledad Vallejos as cited by Rodríguez, 2015).

These remarks acknowledge the groundwork done by multiple women's and feminist organizations in Argentina, which allowed the collective and its followers to swiftly adopt understandings and language that could translate into coalitions and political action. This groundwork includes a number of notable legislative triumphs of feminist advocacy, such as the 2002 Law on Sexual Health and Responsible Procreation, which imposed the free distribution of contraceptives and enabled adolescents to attend medical-gynecological consultations without the authorization of their parents; the 2006 Law on Comprehensive Sexual Education which set a minimum of sex-ed contents in schools; and the 2009 Law 26,485 for the Integral Protection of Women that provided a legal framework to discuss violence against women. The last piece of legislation was of upmost importance for members of $\mathrm{Ni}$ Una Menos as it provided a comprehensive definition of violence against women that encompassed domestic, institutional, labor, reproductive, obstetric, and media violence.

To anchor the mobilization politically, Abbate said (F. Abbate, personal communication, May 5, 2019), members of Ni Una Menos circulated messages in traditional and social media raising awareness about the stipulations of Law 26,485. 
Furthermore, the collective quickly put together a five-point compromise that specified the political goals of Ni Una Menos. These points addressed the state's failure to implement and enforce protections and programs coded in Argentine law that aim to help women victims of violence, such as the National Action Plan for the Prevention, Assistance and Eradication of violence against women, the design of the Integral Sexual Education program and the creation of the Official Unique Registry of victims of violence against women. The collective widely shared this compromise on social media with the hashtag \#DeLaFotoALaFirma - in English, from the picture to the signature - to pressure politicians, especially the 2015 presidential candidates, to incorporate NUM goals to their political agendas. By June 3, all then-presidential candidates, including President Mauricio Macri, and other members of the government signed the five-point compromise.

This outpouring of the movement into state and presidential politics set the tone for the future of Ni Una Menos. Members of the collective made sure to keep violencia machista as a platform for politics, as a platform for collective and transformative action. This effectively departs from what Manuel Castells (2009) argues characterizes social movements developing in digital environments, namely expressive politics - a politics focused on the construction of collective identities. To ground its political thrust, violencia machista became Ni Una Menos' Rome: all grievances led to it.

The mediated work in the weeks before the June 3 demonstration focused on building up a broad and expansive understanding of violencia machista. The struggle against violencia machista became the banner under which activists, politicians, and citizens from multiple partisan, economic, and religious backgrounds could rally together 
without compromising their traditional political positions. "Nobody with a minimum sense of decency anywhere would say that it is okay to kill a woman. The protection from a violent death is straightforward and a big unifier," said Abbate (F. Abbate, personal communication, May 5, 2019). A manifesto published in NUM official website on May 9, 2016 advanced this narrative connecting femicide to violencia machista:

Death is the extreme of violence that aims to discipline women and anyone who rebels against the patriarchal and heterosexual pact. However, la violencia machista also kills slowly when it undermines freedoms, political and social participation, the chance to create other worlds, other communities and other relationships (NUM, May 9, 2016).

Once the political target of $\mathrm{Ni}$ Una Menos was clear, it became a priority for some members of the collective not only to describe but to measure violencia machista. On December 2015, journalist Ingrid Beck and communications researcher Martín Romeo, ${ }^{5}$ both members of Ni Una Menos, started to put together a national online survey to assess the multiple forms in which violencia machista manifests in diverse social contexts in Argentina. On June 3, 2016, the survey launched online. Ni Una Menos turned to Twitter to invite women to participate in the study. After ten days, 32,800 women had already responded. Some participants shared their impressions after completing the survey, and Ni Una Menos decided to share these insights on their official Twitter account to encourage more participation. Ni Una Menos tweeted images with the participants' quotes under the hashtag \#NoNosCallanMás, in English they won't silence us anymore, and provided a link to the survey. Some of the posts read as follows:

"So many times, so innocent. We think that these situations are okay, normal, and they are not. And today they hurt even more. Enough" @SolCasella (@NiUnaMenos_, 2016 June 13).

\footnotetext{
${ }^{5}$ At the time of the study I reference here, Martín Romeo was a faculty member of the University of Buenos Aires.
} 
"The part about obstetric violence... it is so naturalized that humiliating situations happen, and we do not even realize it”@Tatelli (@NiUnaMenos_, 2016 June 13).

"Some things are horrible. It is scary to read. You realize how much you went through and how much you blocked"@Monib253Sovo (@NiUnaMenos_,2016 June 16).

After six months, almost 60,000 women participated in the survey. On November 25, 2016 the official report was published for free online while Beck and Romeo presented the results in a conference at the Universidad Nacional de Tierra del Fuego. The survey served as an awakening. Violencia machista was entrenched in almost every social space that women navigate in Argentina, including their homes, their work, state institutions, and even health services. As these and many other tweets show, women experience violence without realizing it. They "block" the experience, but still they live it. Every day. In the survey report, Beck and Romeo (2016) argue that violencia machista is selfperpetuating, as its most normalized versions, such as catcalling, are the breeding ground for its most brutal manifestations, such as femicide. Beck and Romeo (2016) described 15 dimensions of violencia machista, including harassment in public and private spaces, isolation, devaluing, mistreatment and violence in the context of a romantic relationship, stigmatization, discrimination, obstetric violence, economic violence, and violence against offspring. Furthermore, the study found that none of these dimensions have less than 47 percent of incidence and that 97 percent of the participants have experienced at least one instance of violencia machista in their lives.

For most of 2016, then, the Ni Una Menos' Twitter feed focused on denormalizing and problematizing inconspicuous instances of violencia machista. Many tweets from @NiUnaMenos_presented information and statistics about violence against women in somewhat shocking ways and provided links to websites - including their own 
- that delved deeper into the issue exposed by the tweet. In the months before the publication of the survey's final report, the collective posted graphics of the preliminary results. One of the most shared statistics (by the end of this study it had been retweeted 177 times) showed that 99 percent of women in Argentina had suffered violence just for being women at some point in their lives.

Two events in October 2016 kept adding layers to the grievances targeted by $\mathrm{Ni}$ Una Menos. First, the gang rape, impalement and murder in Mar de Plata of 16-year-old Lucía Pérez, which sparked a new wave of street demonstrations in Argentina and abroad. Second, the annual XXXI Encuentro de Mujeres in Rosario, Argentina, which hosted 70,000 women to ponder about the status of women and women's rights in Argentina. In the opening remarks of the Encuentro, the organizers explicitly criticized the neoliberal policies of the Macri administration which had resulted in the stagnation of salaries and a concerning increase unemployment and inflation rates. Part of this document reads as follows:

All this situation, along with the elimination and downsizing of social programs, threatens our basic rights. Why does poverty always affect women the most? Because we are the ones in charge of the care of family members, children, elders, the sick, and we are the ones sustaining our homes when the transactions of the rich and powerful directly attack the working people. None of Macri's proposals would have been possible without the complicity of other political sectors and, therefore, we need to stay organized and on the streets (ENM, 2016, October 9).

The XXXI Encuentro ended with repression. After confrontations between the attendees of the Encuentro and a group of Catholic protesters who were in front of the Rosario Cathedral, the police of Rosario targeted the attendees of the Encuentro with tear gas and rubber shotgun shells (“Disturbios y balas," 2016, October 9). Some attendees and journalists were wounded and arrested. Ni Una Menos showed support in social media. A Facebook post in the collective's Facebook group reads: 
The demands that were heard during the Encuentro cannot be shut down by institutional violence: the need for legal, safe and free abortion; the demand for a state budget according to the magnitude of the structural problem of violencia machista; the feminization of poverty that today is expressed in 10.5 percent of unemployment; the fulfillment of the Law of Integral Sexual Education that this year celebrates a decade; the guarantee of labor rights for sex workers; the trans work quota; the importance of ensuring the participation of women in unions and political parties and approving gender parity in Congress.... We take the streets to demand autonomy, respect, freedoms and rights (NUM, 2016, October 12).

The Encuentro, in line with the shared history of the feminist and labor movement in Argentina and Latin America, foregrounded the state policies that contribute to the precarity of women's lives and autonomy. The embrace of neoliberalism by the Macri administration emerged as a focal point of concern and, thus, sparked strong opposition among feminist and women's organizations. In this context, Ni Una Menos, along with other organizations had been organizing a Women's Strike for October 19, 2016 to protest Macri's neoliberal policies and renewed alliances with the International Monetary Fund. In a manifesto published in its official website, $\mathrm{Ni}$ Una Menos explicitly drew connections between economic precarity and the violence women experience throughout their lives.

We are living in a hunting season and neoliberalism is testing its strength on our bodies... We strike because all economic variables contribute to violencia machista. Femicides are the result of a series of social and economic aggressions, of pedagogies of cruelty... How do we create a different world if the policies that could contribute to such transformation, such as the Program for Integral Sexual Education, are gutted or not applied in some provinces? How can we be patient when we earn 27 percent less than our male counterparts for the same labor? (NUM, 2016, October 10).

As time progressed, Ni Una Menos' constructions of violecia machista increasingly pointed to the structural factors that make it possible. Violencia machista is seen as rooted in the markets - or more specifically, the neoliberal market -, the criminal justice system, the health care system, the workplace, the media, and the family. In tandem to the 
seminal feminist construction, the personal is political, NUM insists on tracing the origins of violencia machista outside of the home, the private sphere, and the romantic relationship, into the field of national and international economies, human and civil rights, and culture.

This move from the individual to the structural, I argue, is fundamental for the political thrust of Ni Una Menos. It is at the structural level where violencia machista becomes an issue that can and must be acted upon politically and through collective action. Furthermore, a structural understanding of violencia machista allowed NUM to turn its attention to the state as the institution in charge of the protection of women's civil and human rights. During their campaign for the 2017 International Women's Strike, $N i$ Una Menos highlighted on social media the role and negligence of the Argentine state in granting women's rights:

Because only 8 of the 24 jurisdictions abide by the protocols of non-punishable abortions contemplated in the Supreme Court ruling (@NiUnaMenos_, 2017, January 31).

Because maternity leaves are short and paternity leaves are only two days long. There are virtually no day-care services in any public or private work place (@NiUnaMenos_,2017, February 16).

The number and cruelty of femicide is on the rise. There is no place for budget cuts in the eradication of violence against women (@NiUnaMenos_, 2017, February 16).

There is no evidence that the state has fixed the "administrative error" that cuts 67 million of pesos [approximately USD 4.3 million] from their budget (@NiUnaMenos_,2017, February 16).

Twitter followers of Ni Una Menos echoed these critiques to the state. Moreover, the collective's continued foregrounding concerns about the state of the economy and President Macri's neoliberal policies by characterizing these as violencia machista. Ni 
Una Menos even used language that commonly emerges in cases of rape or femicide to talk about the economy throughout 2017 and 2018.

There is no \#NiUnaMenos if public policies do not directly address the violence women face in areas beyond the big cities. There is no \#NiUnaMenos if they don't allocate RESOURCES for policies for gender equality \#StopKillingUs (@ rochinervi, 2017, March 19).

They suffocate us with compulsive debt (public and private) and we are caught up with the institutional violence of the police and the judicial hypocrisy, they are not content enough with popular hunger (@ColectivoNUM, 2018, July 25).

Violence by clandestine abortions that indebt us, violence by being fired and increasing our precariousness, violence by adjusting our daily consumption to get to the end of the month, violence by repression when we fight (@ColectivoNUM, 2018, July 11)

The focus on the state as the main responsible for the eradication of violencia machista even allowed for the reframing of certain issues. For instance, as the collective established an early alliance with the National Campaign for the Right of Legal, Safe, and Free Abortion, an organization that had been active in Argentina for more than 30 years, NUM campaigned for the passing of the bill for the Voluntary Interruption of Pregnancy under the premise that "illegal abortion is state-sponsored femicide and a debt to our democracy" (NUM, 2017, March 8). Considering that clandestine abortions are among the main causes of death for Argentine pregnant women, Ni Una Menos incorporated illegal abortion into its structural construction of femicide and, ultimately, violencia machista. From this understanding, NUM extended its solidarity to other countries in the Latin American region:

We denounce publicly and internationally the femicidal states of El Salvador, Honduras, Nicaragua, the Dominican Republic, Haiti and Suriname. As the only six countries in Latin America with absolute prohibition of abortion, [these countries] are responsible for the deaths and serious violations of the right to health of hundreds of girls and women in their territories (NUM, 2017, March 8). 
As Ni Una Menos constructed illegal abortions as another instance of violencia machista sponsored by the state, it also re-conceptualized motherhood itself. Argentina has a long history in the politization of motherhood. Consider the activism and influence that Madres de Plaza de Mayo as well as Abuelas de Plaza de Mayo still have in the country and abroad. To incorporate motherhood into its structural vision of violence, $\mathrm{Ni}$ Una Menos reframed it as "a human right, not an obligation" (NUM, 2017, September 25). By connecting motherhood with a human rights framework, NUM could focus once again on the state as the guarantor and protector of citizens' rights. Abortion as well as motherhood, then, become vehicles for women to exercise their rights as citizens and the state's regulation of both become not only a violation of human rights, but a threat to democracy.

As the elasticity of the concept of violencia machista kept increasing, a growing number of grievances could fall under its umbrella and, therefore, capture the attention of NUM. By the time of the March 8, 2018 Women's Strike, Ni Una Menos had embraced transnational struggles for environmental protection, indigenous rights, and the decriminalization of immigration. In a manifesto published on January 8, 2018, NUM stated that:

When we say, \#WeStrike we are inventing a we that houses all women, lesbians, transwomen, and all dissident identities in the cis-hetero-patriarchy. We call it an international strike because this tool allows us to make visible, denounce, and confront the violence against us, which is not reducible to a private or domestic issue, but is manifested as economic, social, and political violence, as forms of exploitation and dispossession that are growing daily (from layoffs to the militarization of territories, from neo-extractivist conflicts to the increase in food prices, from the criminalization of protest to the criminalization of immigration, etc.) With the international strike, we value other forms of life and we shout: if our bodies don't count, produce without us. 
At this point, Ni Una Menos shows clear intersectional and transversal traits in its discourse. The fight against violencia machista is fought in multiple fronts that compromise the rights of women who dwell at the most vulnerable intersections of not only gender and sexuality but of race, class, nationality, and neocolonial relations. Consequently, Ni Una Menos operates in line with traditions of feminisms in the global South and Latin America which have defined "women's equality and political rights as the touchstones of democracy" (Tripp, 2006, p. 58). The collective's transnational consciousness and alliances are also in line with the historical development of Latin American feminisms as interconnected and networked regional movements. As these activists link the issue of violencia machista to poor performances of the democratic system in Argentina, Ni Una Menos has called for support across race, gender, sexuality, class, age, and even partisan lines. At this point, then, it is necessary to delve in the construction of $\mathrm{Ni}$ Una Menos' collective "we" that hosts all "dissident identities in the cis-hetero-patriarchy" (NUM, 2018, January 8). The analysis of the structural construction violencia machista next to the intersectional construction of NUM's collective identity renders visible the transversal politics of $\mathrm{Ni}$ Una Menos which I discuss in the end of this chapter.

\section{Forming Collective Identity through Flexible Solidarities}

In this section, I address $R_{1}$, which calls for an examination of the process of collective identity formation within Ni Una Menos. Once the collective's politics became rooted in a structural understanding of violencia machista, diverse and seemingly disparaging individuals and organizations took the mantle of $\mathrm{Ni}$ Una Menos to advocate against different manifestations of this violence. Although the coalition of diverse 
constituencies under the umbrella of NUM brought (and keeps bringing) much tension to the collective, Ni Una Menos retains cohesive and distinctive values and goals. "Today, everybody knows what $\mathrm{Ni}$ Una Menos is and what it stands for. I would say the collective has secured its place in the feminist movement in Argentina," said Marcela Ojeda (M. Ojeda, personal communication, March 23, 2019). This section explores how NUM navigates and encourages intersectionality within its ranks without losing the sense of collective identity.

As noted in previous sections, the seminal moments of Ni Una Menos in 2015 can - and have been - characterized as an explosion. The murder of Chiara Páez sparked a chain reaction in Twitter among people from diverse walks of life who had become fed up, hartos, of learning about the increasing number and gore of rape and femicide in Argentina. In Paula Rodríguez's book (2015), many activists characterized the mood before Chiara's death as a "social rumor." The activists describe a period of deep unsettlement among Argentines who were learning about cases of rape and femicide almost daily. Karina Lopinto, mother of Daiana Ayelén Carcía,19, who was murdered in March 2015, said: “Considering what I had around me, I felt people was increasingly furious with the situation, people were tired about these things happening to young girls" (Lopinto as quoted in Rodríguez, 2015). Furthermore, activists also noted people’s frustration with the media coverage of these cases. References to women's and girl's clothing, their relationship status and the emphasis on recommendations for females to avoid harassment advanced victim blaming narratives. "There was a sincere feeling, an individual scream that became collective: 'Enough, do not fuck me anymore.' Fuck me 
no more with the fucking short, with violence in interpersonal relationships, with

harassment in the street... Enough" (Marta Dillon as cited in Rodríguez, 2015).

Then, on May 11, 2015, Chiara's body was found buried in her boyfriend's family

yard. Fabiana Túñez, researcher who worked in La Casa del Encuentro, noted that:

In Chiara's case, what made the impact worse was that she was a minor, that the murderer was a minor, that [this case] joined two femicides in broad daylight in a restaurant and a confectionery store. But the reality is that for us, who see femicides every day in all the provinces, the situation is repeated. It is like this every day. But for society it was not the same. That is why society reacted the way it did (Túñez as cited in Rodríguez, 2015).

In this context, one tweet by journalist Marcela Ojeda opened the gates for quick assemblage and collective action. When I asked Ojeda to narrate the events of May 11, she went into a description of the effect Chiara's death had on her body. "It was a visceral sensation, an anger the body responds to. You get tense, you get angry, something gets violated inside of you, and my first reaction was to write" (M. Ojeda, personal communication, March 23, 2019). So, this origin story, similarly to many of feminist awakening (Ahmed, 2017), starts in the body: a body loss, a body shaken, a body moved into action. Ojeda looks back at May and June of 2015 with awe. Neither she nor her early Twitter allies knew Ni Una Menos would snowball the way it did:

It was the perfect storm. Today, in hindsight, it was an impressive thing to align positions, to get to know each other. One does not know the people with whom one is going to engage in a crusade. We did not even know that it was going to be a crusade. We thought it [the demonstration] was going to be something very small, 500 people at most. We set up to get the stage, the audio, to see who were going to read the document, to write the document that was going to be read. What were we going to ask for? To whom were we going to make these interpellations? (M. Ojeda, personal communication, March 23, 2019).

However, Ojeda herself is quick to credit the decades of work by feminist and women's organizations in Argentina for doing the groundwork that ultimately led to the constitution of Ni Una Menos in 2015. "Whomever says that Ni Una Menos was born 
overnight is diminishing and not recognizing the history of feminism here in Argentina" (M. Ojeda, personal communication, March 23, 2019). Ojeda is adamant about foregrounding the feminist histories that sustain Ni Una Menos over the media technologies that enabled the rapid mobilization of 2015. "Social media complemented the feminist militancy that was already there. It was not a new militancy, it was a new way of rendering things visible" (M. Ojeda, personal communication, March 23, 2019). As seen in previous sections, organizations such as La Casa del Encuentro had been engaged in pedagogical social work for decades, offering knowledge and language to understand and disrupt violence against women. However, these efforts had rarely transformed into the types of collective action Ni Una Menos set in motion in 2015.

Members of the collective describe the quick rise of $\mathrm{Ni}$ Una Menos as a perfect storm. On the one hand, the feminist movement in Argentina and Latin America had provided the knowledge and the language to quickly articulate grievances publicly and politically. Thanks to the regional networks of feminist journalists, feminist and gender perspectives were not foreign to media professionals in Argentina, including those who launched Ni Una Menos on social media in 2015. Additionally, these media workers were acquainted with other feminists in the fields of journalism, research, community activism and non-profit organizations. On the other hand, social media, especially Twitter, allowed for quick communication and assemblage when it mattered the most. As strong affective reactions were unfolding across civil society in Argentina due to Chiara Páez's murder, a call for action from a well-connected journalist was enough to channel the outrage into political mobilization. 
One of NUM original members, journalist and columnist for newspaper $L a$ Nación Hinde Pomeraniec, ventured an alternative, yet complementary, explanation for the timing of the mobilizations. I haven't seen her position replicated by any of the other NUM activists I interviewed or in any of the online discourses of Ni Una Menos and its chapters. However, her take on the impact of certain femicide cases is telling and signals the relevance of class in the emergence of $\mathrm{Ni}$ Una Menos. Pomeraniec argues that femicides started to get in the radar of mainstream media and wider sectors of the population when it became obvious that femicide was not a problem exclusive to the lower classes or the provinces (H. Pomeraniec, personal communication, April 1, 2019). She cites the case of Ángeles Rawson, a 16-year-old girl who lived in the affluent neighborhood of Palermo in Buenos Aires. In June 2013, Ángeles was raped, murdered and tossed in a trash bag by the security guard of her building, who after a two-year investigation and trial was condemned to life in prison.

The case of Ángeles was paradigmatic in this matter. That it was in the capital, in Palermo, a middle-class girl, who also - and this is very politically incorrect was not a stigmatizable victim, because she did not come to dance, she was not dressed in such and such way. Well, there was nothing to say but the fact that she had been killed for being a woman. You could not look the other way.... In other cases, we still suspect, for example, if it is a married girl, in a years-long relationship, that she made the guy crazy. It is either suspected or implied (Pomeraniec as cited in Rodríguez, 2015).

There is an understanding here, then, about whose lives matter in the public's eyes. Judith Butler (2016), in Frames of War - When is Life Grievable?, argued that in times of war, the sense of collective identity is heavily marked by the question of whose lives are valuable and deserving of protection. This argument can naturally be extended to apply to the formation of the "we" in times of relative peace and to relations not only among war foes but peers. Pomeraniec points to a differential distribution of value among the lives of 
women depending on their background (H. Pomeraniec, personal communication, April 1, 2019). The lives of impoverished, indigenous, trans women outside the capitol are not grieved the same as the lives of middle-class Buenos Aires girls. Sometimes the first group of women is not grieved at all but blamed for their misfortune.

These inequities manifest in the news coverage of violence against women. Andelsman and Mitchelstein (2019), in their study of news coverage of violence against women in Argentina from 1995 to 2015, found that despite a small increase of coverage about this issue, news outlets employed episodic frames to talk about femicide and favored sensationalist narratives about violence. These narratives, Andelsman and Mitchelstein (2018) argue, portray the issue of violence against women in Argentina as an individual instead of a structural phenomenon, placing blame in either reckless victims or pathologically monstrous perpetrators. By the time of Chiara's murder, many Argentines seemed to be taking issue with the way the media and society more broadly treated femicide and rape cases. The father of Ángeles recognized the unrealistic standards women must meet to have their rights acknowledged:

I think as a society we subscribe to the "They must have done something." A woman is raped and... "Well, she must have been wearing a mini-skirt, she got out of the boliche [club] at two in the morning, drunk." The victim is to blame. And no woman deserves to be raped. It seems that, to be able to denounce her rape, the woman ought to be almost a nun. If she isn't, then she has no rights" (Franklyn Rawson as quoted in Rodríguez, 2015).

Paradoxically, even in a situation where society does not grieve and value the lives of all women equally, femicide and rape emerged as the great equalizers because they visibly targeted women of all backgrounds, including the privileged. Once that became clear, large sectors of society changed gears and were able to back an initiative such as $\mathrm{Ni}$ Una 
Menos. Pomeraniec noted the changes from inside the newsrooms, where journalists in charge of crafting the narratives around these cases saw the reality of femicide closing in.

When they [femicidal men] started to target the middle-class girls, when the news makers began to see that it could be their daughters, their nieces, their goddaughters, added to the fact that the crimes could happen in the middle of a bar, in a kindergarten... There, when you cannot stop looking, they started to echo it, and tried to explain, distinguish, have a minimal notion that there is a violence different from others, because they are killed because they are women (Pomeraniec as cited in Rodríguez, 2015).

People identified with and mobilized by Ni Una Menos in 2015, then, engaged in collective action under the principle that femicide was unacceptable. According to journalist and member of NUM, Agustina Paz Frontera, at the beginning her focus in the collective was on the defense of victims of violencia machista. She characterizes this position as a narrow feminist view that constructed women as nothing more than victims of machismo. As she mobilized with Ni Una Menos, Frontera started seeing herself and other women differently.

There was nothing positive, there was no cheerful power in being a woman. It took [me] several years to reverse that, build a critical look, an identity. To face the question of being a woman, the feminine, the positive side, the expanding of liberties, the potentiality of life. Not always must women be on the defensive. Take the street with joy and not hiding from death and violence. It is not about being brave to go out on the street... One must be able to live fully, not according to the violence that is conditioning us. We must define another type of life for women (Frontera as quoted in Rodríguez, 2015).

What Frontera describes here is a shift in her view of woman, from victim to citizen. The moment that shift occurs marks the beginning of an activism that pursues not only the preservation of women's lives but the full inclusion of women in civic life; in other words, the recognition of woman as a subject of human rights. ${ }^{6}$ This construction of

\footnotetext{
${ }^{6}$ Constructing someone as a subject of human rights implies acknowledging the person in their "existential integrity and wholeness" (Yeatman, 2000, p. 1498). This construction acknowledges the individual as entitled to rights and protections, shaping their relationship to the state and humanity in general.
} 
woman also responds to the understanding of violencia machista as a violation of human rights that affects women's relationship to the Argentine state and, thus, their ability to effectively exercise citizenship. The human rights framework that feminists across the globe developed in the 1990s to address the issues and violence women face is seen here at work, granting - or at least attempting to grant - women a more empowered position from which they can engage in politics.

In Twitter, the representations of women navigated this duality of victimhood and empowerment. On the one hand, the Twitter discourse of Ni Una Menos suggests that the movement is largely constituted by women who have themselves been victims of violence. Although the account managers do not openly identify themselves, their use of the collective we includes them as victims when they communicate the grievances of women. All tweets are written in first-person plural and hashtags, such as \#NoNosCallanMás (they do not shut us up anymore), \#NosSiguenMatando (they keep killing us), and \#TodasSomosEllas (we [female] are all them [female]), imply that the tweet writers, are subject to the oppression they describe as well. Indeed, this last hashtag extends the sense of collective identity to the victims of femicide.

Because \#NosSiguenMatando [They keep killing us] join the \#MiercolesNegro [Black Wednesday] \#NiUnaMenos \#TodasSomosEllas (@ NiUnaMenos_, 2016, October 16).

We invite a todos y todas [all men and women] to join, change their avatar and tell the story of a victim of femicide in a tweet \#TodasSomosEllas (@NiUnaMenos_,2016, October 16).

On the other hand, the movement represents women as activists. Women are unequivocally the main agents of the movement. As nouns in Spanish are gendered, it is clear in almost every sentence and call for action that women are the engines of the collective. Although Ni Una Menos's language centers women, there is a culture of 
inclusivity and gratitude toward all the collective's support base. When organizing the first demonstration in June 3, 2015, people started sharing selfies with the hashtag \#NiUnaMenos on Twitter. These pictures show people from all walks of life: Women, men, elders, children, politicians, celebrities, firefighters, students, and more. Those who mobilize with the collective routinely get shout-outs and acknowledgements on Twitter. The pervasiveness of these faces and the consistency with which Ni Una Menos acknowledges its supporters in its Twitter feed signals the purposiveness in the collective's use of pictures. After their demonstration in 2015, Ni Una Menos shared and retweeted many pictures of the impressive crowds that gathered in many Argentine cities. These images became a representation of the movement's supporting base, in terms of both its size and its makeup as individual supporters openly show their identities.

The collective also highlighted its alliance with other organizations throughout Argentina. Many NUM manifestos provide lengthy lists organizations that "adhere" to the collective's cause. Media organizations, university departments, non-profits, unions, religious groups, student organizations, law firms, and more declared publicly their alliance to NUM. These coalitions also seem common for the branches of Ni Una Menos outside Buenos Aires. Agustina Vilte, member of Ni Una Menos Tucumán, stated that her chapter worked closely with dozens of organizations in northern Argentina (A. Vilte, personal communication, April 6, 2019). Vilte herself advocates simultaneously on behalf of Ni Una Menos Tucumán and La Campaña por Aborto Seguro, Legal y Gratuito.

Naturally, this tendency for inclusivity did not come without tensions. As celebrities and politicians started showing public support to Ni Una Menos, some members of the collective became uneasy and concerned about the potential trivialization 
of the collective's politics. There were also concerns about the conduct of some of the celebrities who were showing support, such as television host and producer Marcelo Tinelli, whose popular show ShowMatch was notoriously disrespectful toward women. Marcela Ojeda and Hinde Pomeraniec, who were privy to the internal discussions about the inclusion or exclusion of figures like Tinelli, indicated that despite the concerns, NUM decided to use these controversial supporters to increase the reach of the mobilization and add nuance to their online conversations about violencia machista.

For me, it was good that even Tinelli, who spends his time showing girls in a state of absolute objectification, said: "Well, there is a line we cannot cross." It enabled us to try to reconstruct argumentatively other links... That the lady who watches Tinelli... now has an idea of what Ni Una Menos is seems important to me (M. P. López as cited in Rodríguez, 2015).

That exposure of some famous and popular figures allowed people to question their practices. Someone, for example, sent a sign that read: "Double discourse is also violence." And others, directly, put the comment [in response to Tinelli]: "You contribute to violence, caradura." Social media have that, it is not that because Tinelli posts the selfie everyone will think he contributes to the fight, no. It seems to me that nothing is so univocal, and that people have the capacity to discern and question what they are seeing (F. Abbate as cited in Rodríguez, 2015).

In the case of the role of politicians and political parties in NUM, there were other types of discussions. As indicated in the last section, Ni Una Menos quickly put together a document with political demands for politicians to sign as a gesture of good faith and commitment to the collective's political goals. The hashtag \#DeLaFotoALaFirma functioned as an accountability measure to keep partisanship at arm's length from the core politics and agenda of NUM. Appropriation and depolitization of the cause concerned the activists according to Ojeda (M. Ojeda, personal communication, March $23,2019)$. However, the collective found ways internally and externally to justify and set boundaries to the involvement of political parties in the mobilizations of $\mathrm{Ni}$ Una Menos. 
We had people across all the political spectrum. Journalists in the collective were working for pro-government and anti-government media. That determined who people wanted to hold accountable. For example, pro-kirchneristas wanted to focus on the judicial power and the criminal justice system, anti-kirchneristas were interested in targeting the executive. In the end, we negotiated and prioritized the suffering of women. In that, all bodies of the state were implicated (M. Ojeda, personal communication, March 23, 2019).

We have politicians and we want them as allies. All the parties. Because when they shape the laws, they shape them all. We did not want to fight, we wanted to make demands to them with respect and I think one of the successes of Ni Una Menos had to do with that. When they told us "the government appropriated the march," "the opposition appropriated the march," we responded "Great! Let them all appropriate it. (Florencia Etchevez as cited in Rodríguez, 2015).

In the years following the 2015 demonstrations, Ni Una Menos kept making public interpellations to all the branches of the state. Across the collective's digital platforms, blame for the continuance of violencia machista was almost equally distributed among the Macri administration, highlighting damaging neoliberal economic policies; Congress, noting law-makers' failure to craft preemptive instead of punitive legislation to address violencia machista; and the Judiciary, condemning the lack of enforcement of existing laws and preemptive programs and protections. In a manifesto published in April 20, 2017 called "Not in our name," Ni Una Menos pushed back against a Senate bill that proposed increasing jail time and limiting or eliminating parole for those facing femicide charges. Senators who proposed the bill indicated that they were acting on their commitments to Ni Una Menos, in particular, and the Argentine feminist movement, in general. "Not in our name" explicitly rejected this misappropriation and misinterpretation of the collective's politics and restated the types of legislation and social programs the collective would support. This move shows how protective of its own politics the collective has become. 
This political sensitivity is not gratuitous. It is in its politics where the collective identity of Ni Una Menos is anchored. The adherence to broad principles, such as the acknowledgement of women's right to live free from violencia machista, as well as to feminist understandings, such as the human rights framework and the systemic nature of violencia machista, allows the collective to host diversity in many areas. Race, ethnicity, gender, sexuality, nationality, class, and partisanship difference become irrelevant, yet not flattened, as feminist politics are placed at the core of the transformations the collective attempts to advance. In Paula Rodríguez's (2015) oral history of $\mathrm{Ni}$ Una Menos, all the members that were cited celebrate the heterogeneity of the collective and think of it as a measure of NUM strength. Thinking about the organization of the first June 3 demonstration, researcher and writer Florencia Minici (as cited in Rodríguez, 2015) said:

This type of transversal mobilization, and its traction, are not part of what we saw in the last ten years: the type of mobilization of the Kirchnerism, the left or the right. It was something else: universal enough to place a human rights slogan in a circumstance of social emergency such as the one we are living with femicide.

Considering the ways in which NUM managed the support of celebrities and politicians, it becomes clear that the opposition to femicide functioned as the common denominator that brought activists and civic society to an agreement about violencia machista.

Feminist principles allowed members and supporters of NUM to simultaneously welcome controversial figures to the mobilization and politically challenge and make demands to them. From that platform, I argue, Ni Una Menos engaged in transversal politics (YuvalDavis, 1999; Collins, 2017), where intersectional difference is acknowledged yet nonhierarchical, allowing the collective to advocate for many constituencies without claiming to represent them. The collective's focus on values and goals, instead of specific 
identities or positionalities, underlines its transversal standpoint. In the third paragraph of the Charter of Ni Una Menos (2017), published in its website, the collective foregrounds the its ties to an array of feminist and women's movements while acknowledging the contribution and vulnerability of minoritized and marginalized groups.

We also recognize ourselves in the Mothers and Grandmothers of Plaza de Mayo, in the revolutionary women who were their daughters, in the LGBTIQ movements, in the union organizations and in the piqueteras, in the migrant, indigenous and Afro-descendant women and in the long history of struggles for the expansion of rights. Our freedoms and capabilities come from that tenacity that accumulates historically.

By granting visibility to historic and contemporary movements and organizations, Ni Una Menos signals solidarity and companionship, instead of lying a claim for monolithic leadership. Marcela Ojeda considers that Ni Una Menos' heterogeneity and inclusivity are the main features of the collective. "Whomever says they own, or lead Ni Una Menos lies. This belongs to anyone who marries feminism and its egalitarian ideals. Feminism is welcoming to all" (M. Ojeda, personal communication, March 23, 2019). Furthermore, Florencia Abbate notes the impossibility of hierarchies in the ethical pursuit of justice for women. She asks, "How can you prioritize the suffering of a trans woman, over the suffering of an impoverished woman in the provinces? Can we really put indigenous women before Black women, or immigrants? No. We must fight for all” (F. Abbate, personal communication, May 5, 2019). Hinde Pomeraniec even considers Ni Una Menos should be more of a campaign than a social movement organization because its focus is on the politics, not the constituencies or an organizational structure per se. "Our objectives unite us, not the fact that we are women, or trans, or white or Black. Those differences are there, and we can take them into account, but the main thing is stopping violencia machista" (H. Pomeraniec, personal communication, April 1, 2019). These 
attitudes and practices within NUM signal the incorporation of what Collins (2017) have called flexible solidarities, which allow the collective to address multiple and shifting issues without compromising its core political objectives. This is in line with the collective's adoption of transversal politics (Yuval-Davis, 2003), which calls for the rooting of solidarity and advocacy in shared values and goals instead of specific identities. In the following chapter, I examine how Ni Una Menos' transversal feminist politics shape its mediated activism. But, first, I offer in the following section a brief discussion about the findings exposed in this chapter.

\section{Embodying Transversal Feminist Politics in Argentina}

This chapter has examined the feminist politics of Ni Una Menos since its inception in 2015 to December 2018. After going through different sources of data, it became evident that NUM had consolidated its grievances under the issue of violencia machista. Thanks to the social pedagogical work that feminist and women's organizations had been doing for decades in the region, the collective could quickly focus public attention on the structural factors that contribute to the vulnerability of women in Argentine society. Furthermore, Ni Una Menos adopted the human rights framework to talk about women's rights, which allowed the collective to question the role of the state in the perpetuation of violencia machista not only in the context of romantic relationships and the private, but on the streets, in the courts, at police stations, Congress, church, doctors' offices, the workplace, the media, and more. This way, the purview of Ni Una Menos became expansive as much of the precariousness in women's lives could be and were explained as instances of violencia machista. 
By taking issue with violencia machista as a structural phenomenon and foregrounding it as a trigger for activism, Ni Una Menos could channel the energies of many sectors of Argentine society toward disrupting a single, yet multifaceted, problem. The second section of this chapter described how the relentless focus on feminist values and goals enabled the collective to engage diverse and seemingly disparate constituencies in the struggle. As the suffering of women dwelling at multiple nodes of intersecting oppressions was articulated under the umbrella of violencia machista, Ni Una Menos could find spaces to advocate for multiple forms of domination in multiple political avenues without compromising the values or sense of belonging of the collective's supporters. This strategic flexibility was key to Ni Una Menos' success and puts the collective on a different category of politics, namely transversal politics. In this section, I discuss the meanings and implications of this politics for Ni Una Menos and the ways in which the use of transversal politics potentially positions this collective, and others like it, on a different category of social movement organization.

\section{From Intersectional to Transversal Politics}

In a recent essay, Patricia Hill Collins (2017) has argued that violence is a productive entry point to study the contours of intersectional politics. To address violence, it is necessary to understand the ways in which various axes of identity and oppression interact to enable specific manifestations of violence in society. Furthermore, in the context of the modern nation-state, violence is a key tool in the constitution and stratification of different social groups (Yuval-Davis, 1999). Violence, then, becomes an instrument for the distribution of power and vulnerability among groups, effectively constructing the boundaries of difference that define those groups. Consequently, Collins 
(2017) argues that violence as a social practice and a social issue constitutes a "saturated site of intersectionality" where intersecting power relations are rendered visible (p. 1464). As we delve in an analysis of the origins, nature, and aims of violence, we delve into an analysis of the workings of political domination.

As I have shown in this chapter, Ni Una Menos has engaged in the struggle to define, identify and disrupt violence against women. In doing so, the collective has found itself in an advantaged position to conceptualize and denounce violencia machista as a form of oppression that undermines the ability of women in Argentina to exercise their human and civil rights. By focusing on violencia machista, NUM could articulate the structural and intersectional nature of this violence, which disproportionately burdens women with vulnerability in virtually all aspects of social life: economy, culture, family, religious affiliation and practice, state politics, reproductive politics, etc. In the context of this activism, then, violencia machista is exposed as the tool that enables, organizes and manages the political domination of women.

For feminist collectives like Ni Una Menos, taking issue with violencia machista and its structural dimensions might be key in the efforts to achieve social justice for women. Collins $(1998,2017)$ notes that when acts of violence are seen as random, senseless, individualized and private, violence becomes normalized as a managerial tool for power. In other words, as certain violent patterns become custom, societies start understanding violence as inevitable and even as a legitimate instrument for social discipline. At this point, violence can become codified into law. Collins (2017) cites policies of mass incarceration in the U.S. as examples of racist violence that are so routinized and institutionalized that cease to be read as violence or racism at all. The 
same happens with violencia machista. As Ni Una Menos and others in feminist movements across the world have noted, violence against women is normalized to the point that women are blamed when they become victimized by it.

Once violence is hegemonic, it shapes our understandings of different social groups. Staying with Collins' example, as African-Americans are systematically incarcerated in the U.S., they become criminalized and vilified as a group. In the arena of gendered power relations, violence constructs women as lesser than men, as naturally confined to the private sphere and motherhood, as sexualized objects, as unfit to vote or rule, even as victims. Ni Una Menos shows awareness of this as it resists the construction of women as disempowered and alienated. Their conscious move from women as victims of patriarchy to women as protagonists of their own liberation is evidently in tune with their understanding of the political effects of violencia machista. Exposing the role of violence in the constitution of identities allows us to part ways with essentialist notions of difference and pay attention to the material and political conditions that group people to render them powerful or powerless (Yuval-Davis, 1997). This way, new possibilities for empowerment and political intervention open for movements.

In the case of Ni Una Menos, the focus on violencia machista allowed them to constitute a collective identity based on shared feminist values, instead of shared identities. As the collective carried on its political interpellations and interventions, it expanded its constituencies, forming coalitions with diverse actors and organizations. The sense of belonging in Ni Una Menos resists fixed or essentialist notions of identity. It is not about being a woman, a woman who has experienced violence, or a man, or a trans 
woman. The sense of belonging is not even dependent on openly adhering to feminist politics.

This notion becomes evident in the digital discourses and practices of the collective. As shown in this chapter, the collective consistently shares photos and shoutouts to followers who communicate their support to Ni Una Menos online regardless of their background. The collective's manifestos also show how its solidarities reach across axes of difference and oppression, allowing NUM to advocate for diverse constituencies and causes simultaneously. Finally, the collective publishes the names of the organizations and institutions it has established coalitions with, which communicates the reach and diversity of their network. This way, membership and belonging are traded based on opposition to forms of violencia machista.

I use the construction "forms of violencia machista" intentionally, as Ni Una Menos does not push a univocal understanding of what those manifestations of violence look like or which ones deserve more attention in the public sphere. As noted by activists in this study, factors such as socioeconomic and marital status, age, location, and behavior played a role in the media coverage of cases of rape and femicide. Condemnation to violencia machista seemed to depend more on the status or profile of the victim than the intrinsic injustice of the violent act. Ni Una Menos through its mediated discourses and activism aims to shift these narratives by rendering all forms of violencia machista in all contexts unacceptable in democratic society. This way, the collective created a space where diverse groups with diverse political positionalities could voice and resist the manifestations of violencia machista that affected them. Under the umbrella of NUM, then, one can find pro-life and pro-choice groups, passionate 
Catholics and LGTBQI activists, members of all political parties, grassroots organizers, government officials, and NGO executives. These positionalities do not compromise, however, these groups' ability to take the mantle of $\mathrm{Ni}$ Una Menos. Some groups even take the option to limit their visibility when dealing with certain issues while becoming more vocal when others come around.

A good example of this is the struggle for abortion and reproductive rights. For some supporters of NUM, abortion is a violation to the right to live and they have communicated their opposition to the collective's alliance with organizations, such as the Campaña por el Aborto Legal, Seguro y Gratuito. The topic of abortion was even avoided during the seminal moments of Ni Una Menos in 2015 to enable the participation of both pro-life and pro-choice groups and individuals in the demonstrations to stop femicide - NUM members were especially mindful of these sensibilities as some of the relatives of femicide victims were pro-life. National media in Argentina have highlighted this internal tension and at times portrayed it in misleading ways. For example, before the June 3 annual march in 2018, the mothers of Ángeles Rawson and Chiara Páez appeared in a video opposing Ni Una Menos' support for the legalization of abortion, a topic that had gained visibility for the march. Argentine newspaper $L a$ Voz reported this as the "main faces of Ni Una Menos" being pro-life (“Aborto no es Ni Una Menos,” 2018). Anti-abortion positions, however, have never found a home in the digital discourses of $\mathrm{Ni}$ Una Menos. Marcela Ojeda indicated that this type of coverage has been difficult to deal with, as Ni Una Menos balances its pro-abortion activism with its loyalties to figures such as Páez and Rawson (M. Ojeda, personal communication, March 23, 2019). 
The collective seems to address this tension with pro-life supporters with silence. Ni Una Menos does not single out anyone in its own base who does not adhere to the movement to legalize abortion. Through the tension, the focus remains on broad values and the objectives. As the collective has constructed abortion as a form of state-sponsored machista violence, Ni Una Menos' solidarity with pro-abortion efforts comes across as natural in the collective's online spaces. In solidarity with La Campaña, NUM has changed its colors from violet to green across its digital platforms and coordinated demonstrations to advocate for pro-abortion bills. Furthermore, some members, such as Agustina Vilte from Tucumán, advocate for NUM and La Campaña simultaneously, shifting and combining flags as they see fit to achieve their goals.

The way members of $\mathrm{Ni}$ Una Menos negotiate the tensions within their constituencies without threatening the cohesiveness of the collective mirrors the concept of flexible solidarities, defined by Patricia Hill Collins (1998). While studying the forms of political action by Black women intellectual-activists, Collins (1998) noted that alliances in African-American communities were largely founded on relationships of compromise and contestation. The political engagement of Black women has historically called for sophisticated balancing acts between full support of anti-racist activism and strong opposition to anti-woman as well as queer-phobic and trans-phobic sentiments and practices in the Black community (Collins, 2006). Unquestioned solidarity from Black women is, to put it simply, not a viable option to achieve their own liberation. A flexible understanding of solidarity for Black women, then, yielded much more potential for the meaningful articulation of the Black feminist positionality and the improvement of the lives of African-American women. Considering that analyses and oppositions to 
violencia machista call for situated understandings of its manifestations and effects, $\mathrm{Ni}$ Una Menos' embrace of flexible solidarities provides the collective with a more potent political impetus.

Nira Yuval-Davis brings up a similar point as she builds her understanding of transversal politics. "Transversal politics recognizes the differential power positions among participants in the dialogue, but it nevertheless encompasses these differences with equal respect and recognition of each participant" (Yuval-Davis, 1999, p. 98). The practice of transversal politics resists assimilation and essentialism, favoring the assemblage of diverse positionalities and standpoints. Considering the online discourses of Ni Una Menos and its members, the collective seems to be striving toward the praxis of transversal politics to effectively fight violencia machista from many fronts. The collective seems more concerned with advocating for the end of this violence than representing or even leading constituencies in the struggle. These transversal politics, as Yuval-Davis (1999) points out, are geared toward the creation of "epistemological communities" that share value systems across difference in order to advance political agendas that uphold those values.

The positive potential of these politics is evident. However, once we examine the ways in which transversal politics work on the ground as well as on mediated environments, it becomes evident that even the praxis of transversal politics does not grant equal visibility to all the constituencies that might find a home in a movement. In contexts already imbued in inequity, movements practicing transversal politics can also find themselves struggling to provide a fair share of exposure and attention to the grievances of constituencies dwelling at the most vulnerable nodes of intersectional 
oppressions. The following section discusses some of these challenges, specifically the ones that emerge in digital environments like the ones that saw the rise of Ni Una Menos.

\section{The Digital Challenge to Transversal Politics}

Despite the significant success of $\mathrm{Ni}$ Una Menos in mobilizing large portions of the Argentine public around feminist values and objectives, it would not be wise to romanticize collective or gloss over its internal tensions. Regardless of these tensions not being evident in the online discourses of the collective, it is important to consider how pre-existing power dynamics in material and digital spaces shape its political and communication practices. After going through the available data and the findings in this chapter, it became evident that national and transnational power dynamics impose regimes of visibility (Fernandes, 2015) that allow professional activists from Buenos Aires cast a larger shadow within the collective.

As this dissertation draws its findings mostly from the digital discourses of $\mathrm{Ni}$ Una Menos, an overrepresentation of the positions and discourses of the Buenos Aires chapter of the collective has been virtually inevitable. While the Buenos Aires chapter possesses the social and financial capital to construct digital content that is both aesthetically and intellectually sophisticated, many NUM chapters in the provinces limit their digital presence to comparatively rudimental Facebook groups and Twitter accounts. Furthermore, the chapters from the provinces clearly identify themselves as such, while the Buenos Aires group labels their digital spaces with names that imply that they stand for the entirety of the movement. For instance, the Buenos Aires Facebook account is @NUMArgentina and on Twitter the chapter goes by the handle @ColectivoNUM. This 
way, the messages posted in their website and social media platforms come across as being representative of all Ni Una Menos chapters.

This practice misleads the observer into thinking that there is some sort of organizational hierarchy within Ni Una Menos, in which the Buenos Aires group represents the spinal cord of the collective, while the provinces constitute a peripheral nervous system. It was during my interview with Agustina Vilte that I realized this assumption was indeed a mistake. "We [Ni Una Menos Tucumán] don’t follow any directives or get any money from the group in Buenos Aires. Our issues and agendas here are very different from the problems in Buenos Aires, so we focus on our own" (A. Vilte, personal communication, April 6, 2019). Considering the Facebook posts of Ni Una Menos Tucumán and Vilte's remarks, the most trying issue in this northern region has to do with the Catholic Church's influence in state policies, especially when it comes to health care and reproductive rights.

A recent case illustrates both Tucumán's particular conflict with the church, and the relationship between different branches of Ni Una Menos. On January this year, an 11-year-old girl went to the Hospital Eva Perón asking for an abortion. She had been raped by her grandmother's boyfriend and was 16-weeks pregnant. The hospital staff did not grant her request immediately despite abortions in the context of rape being legal per the Law 26,485. "The director of the hospital in Tucumán denied her the right for an abortion. He made his decision after consulting directly with the town bishop" (A. Vilte, personal communication, April 6, 2019). When the mother of the girl contacted Vilte through a direct message to the NUM Tucumán Facebook page, Vilte mobilized her network to connect the family with legal counsel and other resources. In February, a 
judge mandated the hospital to uphold the girl's abortion rights, and at 25 weeks of gestation doctors practiced a c-section. Vilte noted that, because the case got national and international coverage, many branches of Ni Una Menos, including the Buenos Aires one, spoke out about the case, followed up on social media, and offered support. "I got more logistical help from La Campaña [por el Aborto Legal, Seguro y Gratuito], though. They have been dealing with these cases for decades. Ni Una Menos helped with visibility and mobilization" (A. Vilte, personal communication, April 6, 2019).

My conversation with Vilte made me go back to my interview with Marcela Ojeda, who currently is not a formal member of NUM, and get a deeper understanding of her insistence about Ni Una Menos not belonging to any particular group. "Those who say that they speak for $\mathrm{Ni}$ Una Menos are lying. This movement belongs to everyone" (M. Ojeda, personal communication, March 23, 2019). Hinde Pomeraniec's remarks about how NUM should be more of a campaign than an organization also become clearer in this context. A concern around internal appropriation seems to exist among some founding members of the collective. The Buenos Aires group might be - knowingly or unwittingly - dominating the digital discourses and appropriating the political thrust of $\mathrm{Ni}$ Una Menos. Unless a regional NUM chapter gets involved in a high-profile case such as the one in Tucumán, they do not get as much media exposure as the Buenos Aires group.

The digital presence of Ni Una Menos Buenos Aires does obscure the fact that it does not speak for or has authority over the other NUM regional chapters. It generates higher volumes of content on professionally-designed websites and social media accounts. The messages themselves - including manifestos, studies, news stories, and social media posts - implement aesthetics, language and constructs that show great 
amounts of political sophistication and media savvy. Some NUM Buenos Aires

manifestos are even translated to English in their website. Furthermore, many of the members of NUM Buenos Aires are media professionals themselves, which endows this chapter with a highly skilled volunteer base. Fenton (2016) argued that the digital proficiencies of members of the middle- and upper-class across the world allow them to enhance their visibility and influence on digital environments as they can better articulate their politics while taking full advantage of the connective and interactive capabilities of the Internet. These digital inequities, then, might explain the dominant position the Buenos Aires chapter enjoys online.

These dynamics in mediated spaces, however, signal to another set of tensions within NUM. Some of the original members, apparently, envisioned a more open-ended transversal form or organizing without much desire for the professionalization of the collective. Other factions, mostly based in Buenos Aires, might be going on a different direction; creating a Charter, periodical manifestos, a digital feminist news outlet, bills, transnational coalitions, and more. These practices at the end of the day create a more institutional image for this faction of collective in the digital landscape, arguably at the peril of other chapters with less resources and expertise at their disposal. To fully assess the effects of such disparities, however, ethnographic fieldwork would be necessary. Since the ethnographic work of this dissertation was done in digital spaces only, I do not venture definitive arguments about the power relationships that tie the different chapters of Ni Una Menos together. 
Marcela Ojeda, however, does not worry about the current state of NUM. She even warns against characterizing these tensions and her exit from the collective as a pelea de mujeres - a catfight:

Nobody is indispensable in a movement, and nobody should have ownership over it. I support the collective anytime they make a call for action. The 2015 group always supports and shows up. But it's not like we are famous, nor we want to be. We just walk around now, and nobody knows what we did. The ex-members keep fighting to conquer other spaces and improve other conditions. The goal remains the same: The fall of the patriarchy; the end of femicide and rape; equality for women everywhere. That is Ni Una Menos (M. Ojeda, personal communication, March 23, 2019).

The larger objectives and values of Ni Una Menos emerge here again as the common ground, as the basis of a collective identity. The feminist transversal politics of $\mathrm{Ni}$ Una Menos, then, follows the patterns of "rooting" and "shifting" Yuval-Davis (1999, p. 96) described. The collective roots itself in feminist values that translate into a sustainable desire and will to eradicate violencia machista. These roots, however, do not stifle the collective but enable it to shift its focus to allow activists of different identities and political positionalities to pursue the collective's goals in diverse arenas and geographic locations. This way, activists under the mantle of NUM can address issues from abortion to neoliberal violence, from neocolonialism to femicide without losing sight of their core values or compromising their sense of belonging to the collective. These negotiations must be further explored through traditional ethnographic work to get a full understanding of the complex relationships this collective harbors. As Hine (2000) appropriately pointed out, virtual ethnographies, such as this one, are inevitably partial.

The next chapter goes into answering the second research question I posed in this dissertation. There, I examine the role of media in the constitution of Ni Una Menos. The findings in that chapter, then, flesh out the ways in which the transversal feminist politics 
of $\mathrm{Ni}$ Una Menos have shaped its media practices as well as the ways in which digital media technologies have shaped the strategies NUM employs to advance its political goals. 


\section{CHAPTER FIVE: TRANSVERSAL FEMINIST POLITICS ONLINE: THE MEDIATED ACTIVISM OF NI UNA MENOS}

In the previous chapter, I provided the results of my critical examination of the feminist politics of Ni Una Menos and how those politics shape their constructions of grievances and collective identity. The findings suggested that the collective engages in transversal feminist politics, which enables it to ground its activism on values and goals instead of identity or political positionality. In other words, Ni Una Menos is involved in patterns of "rooting" and "shifting" (Yuval-Davis, 1999, p. 96), where the collective entrenches itself in the will to eradicate violencia machista, while adjusting its political interventions to address the multifaceted manifestations and effects this issue has on the lives of individuals whose standpoint is invariably shaped by intersectional power relations. This way, the collective hosts and advocates for diverse - and sometimes incompatible - constituencies in diverse arenas without severely compromising its core values and political objectives.

The praxis of this transversal feminist politics, however, is not separate from the inequities that already shape the environments it aims to intervene. In the examination of the online discourses of Ni Una Menos, a disparity between the Buenos Aires chapter and the rest of the provincial branches of the collective started to emerge. The online platforms and messages by NUM Buenos Aires showcased significantly higher levels of communication acumen, in terms of the (academic-like) quality and aesthetics of the discourse. I noted in the discussion of the findings in chapter four that these disparities could respond to deeper inequities structuring relation in both material and mediated 
spaces which grant activists in the capitol more opportunities for political expression and intervention online. Here, I delve deeper into the mediated activism of Ni Una Menos to further comprehend the dynamics teased in the previous chapter.

Access and uses of communication technologies have been found to have the potential to stratify constituencies within movements and communities in artificial - that is, within the realm of mediated representation only - and real ways - that is, in the material world. Media scholar Liesbet van Zoonen (2002) has argued that interactions with communication technologies might reshape the meaning-making processes and structure of entire communities online and offline. However, it is also true that communication technologies only gain relevance through the way people use them in their own context (Friedman, 2017). In the case of social movements, communication technologies and media, then, are more than just tools for the expression of political views and coordination of collective action.

Consequently, to further understand the transversal feminist politics of $\mathrm{Ni}$ Una Menos, it is necessary to take a closer look into the collective's relationship with media as well as its own practice of mediated activism. The second research question of this dissertation addresses this by asking how media and mediated practices have shaped the activism of Ni Una Menos. I answer this question in two major sections. First, I examine the collective's relationship with Argentine mainstream media from NUM's inception in 2015 until December $2018\left(\mathrm{RQ}_{2 \mathrm{a}}\right)$. In the second section, I explore how Ni Una Menos employed communication technologies, specifically digital platforms, to advance its political goals $\left(\mathrm{RQ}_{2 \mathrm{~b}}\right)$. After presenting these findings, I incorporate a final section with a discussion of the theoretical implications of the results. 
This chapter, then, advances a two-fold argument about the mediated dimension of the activism of Ni Una Menos. Broadly speaking, this proposition suggests that the complex relationships between the legacies of the feminist movement in Argentina and the media environment rendered equally complex and seemingly paradoxical power dynamics within the collective. More specifically, by examining the intersection of media and politics, I could observe how members of $\mathrm{Ni}$ Una Menos constructed mainstream media and journalism as sites of intervention in the struggle against violencia machista while building its own digital spaces to showcase correctives to symbolic violence as well as exercise prefigurative politics (Yates, 2015). However, as the collective inhabits material and mediated environments signed by inequity, disparities inherent to these spaces permeated the structure and practices of Ni Una Menos.

\section{Taking Issue with Mainstream Media: Symbolic Violence as Violencia Machista}

I have described before how, in the months before Chiara Páez's death on May 2015, the public's awareness about violence against women was on the rise in Argentina. La Casa del Encuentro had published earlier in the year their report on femicides with the shocking finding of one woman being murdered every 30 hours in the country. Moreover, unsensitive media coverage of cases of rape and femicide had been unsettling not only feminists and relatives of victims but wider sectors of Argentine society. In Paula Rodríguez's (2015) book, many activists, celebrities and citizens complained about the ways in which news media engaged in blatant victim blaming when covering rape and femicide. Like in other locations where rape culture has been identified and denounced, Argentine media commented on the clothes and behavior of victims, implying that, for instance, sexy clothing and attitudes as well as intoxication during late hours were 
contributors to the victims' fate. Hinde Pomeraniec remembers that, in some news outlets, it was common practice to go through a victim's social media accounts looking for revealing photos or compromising comments. "They would just publish the most provocative picture they could find and suggest, sometimes openly, that the girl had brought it on to herself' (H. Pomeraniec, personal communication, April 1, 2019). Ni Una Menos echoed these concerns in the document it crafted for its first demonstration on June 3, 2015:

At the core, they [the media] appeal to the "They [the victims] must have done something." We need media that are committed to the elaboration of protocols, and the application of existing protocols and codes of ethics for the journalistic coverage of [femicide and rape] cases (NUM, 2015, June 3).

Awareness about the harming effects of disparaging media representations of women and women's issues was already significant in Argentina. After decades of work by the feminist movement, the 2009 Law 26,485 listed symbolic violence as a type of violence against women. The law defines symbolic violence in article five, declaring that stereotypes, messages, icons and symbols that reproduce and naturalize the "domination, inequality and discrimination [of women] in their social relations" are thereby outlawed. Furthermore, the Law of Audiovisual Services, also passed in 2009, specified as a goal the protection and safeguard of "equality between men and women, the plural, egalitarian and stereotype-free treatment, avoiding all gender and sexual discrimination" (as quoted in Hasan \& Gil, 2014, p. 47). These laws illustrate not only successes of the Argentine feminist movement, but the levels of concern abound the mishandling of women's representation in the media.

In 2015, as news stories about harassment, rape and femicide increased, frustration in the public increased as well. María Florencia Alcaraz, journalist and 
founding member of Ni Una Menos, said to Rodríguez (2015) that high-profile cases of violence against women started to happen in the public scene, which attracted more media attention. Some cases even involved victims turning to social media to demand justice. One of such cases involved then 20-year-old Aixa Rizzo, who had to use pepper spray to defend herself against harassers outside her home in Buenos Aires. When she tried to file a civil lawsuit against the men, police turned her down. Rizzo published a YouTube video about her story that amassed 550,000 viewers. Shortly after, there were three legislative proposals to outlaw catcalls in Argentina (Erbentraut, 2015).

The Rizzo case had resonance not only because of Rizzo's experience and reach on social media. Media outlets contrasted this story with the problematic remarks Mauricio Macri made a year earlier when he was the mayor of Buenos Aires. Macri said he did not take women who complained about catcalls seriously because "Basically, all women like to be told compliments. Even when you say something rude, like 'What a cute a** you have', it's all good" (Macri as cited in Brady, 2014). In the context of the presidential race, where Macri was a candidate, Rizzo's experience gave more visibility to the issue of street harassment and the negligence of public officials, law enforcement and the state. However, the partisan weaponization of the issue was also exasperating for some. Vanina Escales, member of $\mathrm{Ni}$ Una Menos, said that seeing the media treating these types of news so frivolously took people in Argentina to a "collective breaking point" (Escales as cited in Rodríguez, 2015). Such was the mood when Marcela Ojeda reacted to Chiara's death on Twitter, setting in motion a domino effect that resulted in the creation of the collective Ni Una Menos. 
After Ni Una Menos was consolidated as a political force in Argentina, members of the collective kept taking issue with the role mainstream media played in the reproduction of violencia machista. Activists from the Buenos Aires chapter were particularly vocal about news media's involvement in symbolic violence when covering stories about rape, femicide or abortion. For instance, after a problematic interview with a victim of domestic violence that aired on national television, Ojeda tweeted: "After the [question] 'What did you do to get him to beat you?' some keep finding a home in news media, eh?”(@Marcelitaojeda, 2016, May 7).Ni Una Menos activists also targeted the sourcing and framing of issues in news media, connecting problematic narratives to violencia machista and sometimes offering correctives.

[She] had a spontaneous abortion and Fabián López [for newspaper La Nación] headlined saying that she killed her baby. The double standard of media is also violencia machista (@florencialcaraz, 2016, April 29).

In the country of \#NiUnaMenos the media tell a survivor that her testimony is not enough. That she needs others to "confirm" (@florencialcaraz, 2016, Nov 24)

Abortion is not a moral or religious issue: it is a public health issue. I'd like to see the whole medical community speaking up publicly. More doctors like @mario51obs in the media talking about health (@ fetcheves, 2018, February 6).

Frustration with mainstream media kept appearing as a motivator for collective action. In a call for a women's strike in 2016, NUM Buenos Aires asked on Facebook, "How do they want us to take care of ourselves if at the same time the media tell us that it would be our fault if we are alone and end up dead?” (@NUMArgentina, 2016, October 19). A year later, this chapter elaborated on symbolic violence in a manifesto that listed the reasons why Ni Una Menos was calling for a women's strike on March 8.

We stand against the symbolic violence exercised by the media, the crystallization of gender stereotypes, the stigmatization of our decisions, the invisibilization of our struggles. We are not ornaments! We want more feminist voices in all political, economic, social, cultural debates, we are producers of meanings and 
struggles in all areas Stop talking for us! (Ni Una Menos [Buenos Aires], 2017, March 8).

In its inception, however, Ni Una Menos focused on consolidating alliances with mainstream media to promote the June 3 demonstration and the cause against violencia machista. To control the media narratives, in 2015, the founding members of $\mathrm{Ni}$ Una Menos in Buenos Aires used their media contacts to get exposure in various news outlets. Mercedes Funes, journalist and editor for the magazine Gente, remembers trying to keep track of the news articles published about NUM. She kept clips from regional, national and international news outlets until the coverage was so extensive that she could not keep up. "We went out to all the channels giving press packages. We worked our links to the press a lot. All of us gave out contacts" (Funes as cited in Rodríguez, 2015). The collective, then, benefitted enormously from the previous connections and media savviness of its founding members, who could activate their online and professional networks to get the seminal 2015 demonstration off the ground.

The need and struggle for fair media representation quickly became a concern, though. Activists in 2015 recognized that mainstream media exposure, although badly needed for broader reach, could be risky to the political goals of the collective. Valeria Sampedro, journalist for broadcasters $T N$ and $E l T r e c e$, indicated that dealing with the media was a balancing act, in which the activists needed to simplify meanings to reach larger sectors of the population without draining the message of political impetus. "There was a fear about the banalization of the message... We had to translate everything to one line, a message light in one aspect but with depth. We knew this had been born with the possibility of it becoming empty" (Sampedro as cited in Rodríguez, 2015). In this context, the consistent efforts of the collective to set records straight and vocalize media 
mischaracterizations of $\mathrm{Ni}$ Una Menos, the issues it addresses, and its goals gain significance. These complex dynamics with media and the mediated aspects of activism are not exclusive to $\mathrm{Ni}$ Una Menos, as many scholars have observed most social movements struggle with mainstream media for the power to define (Waisbord, 2018; Couldry, 2013; Ryan, 1991).

The efforts of Ni Una Menos to render violencia machista visible in the work and practices of mainstream media did not go unnoticed. In 2017, the Konex Foundation, an Argentine cultural non-profit organization created in 1980, offered to prize NUM with an honorary mention in the communications and journalism division of its Konex Awards. The collective rejected the award arguing that $\mathrm{Ni}$ Una Menos is first and foremost a social movement whose focus is on disrupting social issues affecting women, not on the mere reporting of such issues. NUM added the following reasons in an explanatory thread on Twitter.

3. The absence of journalism specialized on gender issues among the works that have been awarded [the Konex Award] this last decade is concerning to us. (@ColectivoNUM, 2017, September 12).

4. It is hard for us to understand that such an important category can be ignored when considering acknowledging excellence in communication and journalism. (@ColectivoNUM, 2017, September 12).

This rejection is a nod to the concerns that members of Ni Una Menos in Buenos Aires had been voicing regarding not only the nature of news coverage, but the status of women in the Argentine media industry. Those in the ranks of NUM Buenos Aires who were also journalists took issue with the insufficient representation of women in newsrooms, connecting it with the lack of a gender perspective in media coverage. A gender perspective, as defined by networks of feminist journalists in Latin America, recognizes the gendered aspects of oppression, openly addressing the structural mechanisms that put 
women, trans women and gender fluid people in positions of risk and vulnerability in society (Hasan \& Gil, 2014). The outcry for women and feminist representation in media was evident among media workers mobilizing for $\mathrm{Ni}$ Una Menos, as illustrated by the following tweets:

There are almost no women editors in the big newspapers. Politics is male (@ myriambregman, 2017, May 25).

In Argentina, only $15 \%$ of the bylines are female. There is no parity in the media. Therefore, on \#8M [March 8] we also strike (@florencialcaraz, 2017, February 26).

Happy day? Flawed Media: in times of \#NiUnaMenos only a third of anchors [in radio and television] are women (@Marcelitaojeda, 2017, June 7).

To bridge the gaps, some activists called for feminists to lean into conversations in mainstream media. In a tweet posted on March 2018, Hinde Pomeraniec, reporter and columnist for La Nación, called feminist academics, analysists, and intellectuals to "overcome their phobia" and start making television and radio appearances. "Get out of Twitter and Facebook and take the public scene; while women ask for their rights, men are the only ones who talk about politics in the media" (@ hindelita, 2018, March 10). Earlier that year, anchor for Todo Noticias, Florencia Etcheves, said on Twitter that as a “personal challenge” she was talking about women's issues and feminism on nonfeminist media (@fetcheves, 2018, January 5) to bring more exposure to these topics in the mainstream.

Initiatives like these speak volumes of the levels of access these women had to mainstream media. As many of these activists already held positions in national newspapers, television and radio, they were in a privileged position to put Ni Una Menos in the media agenda. Their working relationships and expertise allowed them to deftly construct messages that met requirements for publication on mainstream media. 
Moreover, NUM Buenos Aires members had the training to make effective media appearances. Activists operating from the provinces did not have such access. Outside Buenos Aires, women of less privileged walks of life answered the first call of $\mathrm{Ni}$ Una Menos, mobilizing mostly their local networks - i.e., neighbors, survivors and their relatives, workers and volunteers in local NGOs and refuge homes, etc. (A. Vilte, personal communication, April 6, 2019). This way, the Buenos Aires chapter had a head start, not just because it was the first to assemble, but because it was - as far as I can tell - the only one that could position its members as authority figures in mainstream conversations about femicide and violencia machista.

After a while, activists in Buenos Aires showed concern about some of the dynamics with the media. These concerns, however, did not address the disparity of media representation between the movement in Buenos Aires and in the provinces. Instead, the activists noted that most of the burden of conscientization and social pedagogy was still falling on women's and feminists' shoulders. At least on those who had the means, contacts and abilities to hold and claim a space in mainstream media. On a Twitter thread, Marcela Ojeda noted that there was still a long way to go when it came to incorporating gender and feminist perspectives in all types of media. Ojeda, however, reserved her harshest criticism for mainstream media: 'I don’t talk about the cooperatives and community radio stations but about the media that HAVE THE MEANS to professionalize their content” (@ Marcelitaojeda, 2016, November 23).

Here, Ojeda shows awareness about the disparities that separate the production capacities of mainstream and alternative media. Despite their efforts, cooperatives and community radio stations cannot carry all the weight of movements' media and political 
interventions. To assert change, Ojeda argues, mainstream media ought to be transformed as well. Interestingly, Ojeda frames this transformation as further professionalization in the journalism and media industries. Ojeda's understanding of journalistic professionalism, then, includes the application of feminist competencies, such as the ability to apply gender perspectives to the analysis and coverage of social issues. This intervention is certainly informed by Ojeda's own background as a reporter. Her knowledge of such specific faults in the profession is shaped by her own experience and connections to feminist networks that have advanced similar arguments about the lack of gender perspectives in journalism.

Other Buenos Aires activists who were also media workers foregrounded structural issues within the media industry. Reporter for Radio Nacional María Florencia Alcaraz was quite vocal on Twitter about the additional labor imposed on women journalists who were cognizant of gender perspectives. Once NUM Buenos Aires popularized language and knowledge to disrupt violencia machista in 2015, mainstream media demanded to hear more from feminists. However, as Alcaraz points out, these requests for quotes and interviews did not open permanent spaces and positions for feminist media workers in mainstream media, which maintained their perspectives on the margins.

I thank all the producers who summon me, but feminist journalists need to rest, train and reflect as well. We are missing in the media, but we are not able to cover the gaps of a system that excludes us every day (@florencialcaraz, 2018, December 13).

We are not opinion-makers, we are workers and we want to work on radios, on television panels and write articles. Feminist journalism is not an opinion: it has spent years constructing a perspective from data collection, from specific sources, from specialization (@ florencialcaraz, 2018, July 5). 
The critiques of Ojeda and Alcaraz resonate with the approach of feminist journalism networks in Latin America that have been training journalists to adopt feminist understandings in their work to improve reporting since the early 1990s. The embrace of gender perspective is seen here as a corrective to issues like symbolic violence in the media. As this type of violence is part of conceptualizations of violencia machista, it is natural that $\mathrm{Ni}$ Una Menos recognized the media as a site for feminist intervention. Furthermore, the fact that many members of NUM Buenos Aires are themselves journalists and media workers sensitized the collective to problems regarding media representations of women and news coverage of violencia machista. This awareness even took some NUM Buenos Aires members to create their own online feminist news outlet, LatFem, in 2017, further signaling the professionalism of this chapter in digital spaces. It is telling that these interventions are only carried out by members with the professional background and networks necessary to have a voice on mainstream media. While members from other provinces get news coverage almost exclusively in the context of scandalous injustices, like the Tucumán case, Ni Una Menos activists in Buenos Aires have to a degree routinized their presence in the media. Despite the egalitarian values and goals of the collective, the stark power differentials between media professionals in the capitol and non-public figures in the provinces influence the nature and amount of media exposure and recognition each group gets. Consequently, NUM Buenos Aires' symbolic power affords it a dominant position within the collective, at least in mediated spaces. The next sub-section explores one of the digital initiatives of $\mathrm{Ni}$ Una Menos Buenos Aires that further elevates its profile online. 


\section{Targeting Journalism: Feminist Interventions in LatFem}

Apart from advocating from the digital platforms of $\mathrm{Ni}$ Una Menos, some members of the collective have taken the initiative to create separate digital spaces to further the politics of the collective. One of the most prominent sites is LatFem, a feminist news outlet that some journalist members of NUM Buenos Aires have created to specifically address the media dimension of violencia machista. LatFem launched in early 2017 to engage and exemplify feminist journalism in Argentina.

In its mission statement, LatFem explicitly questions "uncritical journalism" that fails to "observe diverse realities," and problematize "inequalities, while reproducing a status quo rooted in patriarchal narratives" (LatFem, n.d.). The statement clearly resonates with the arguments of standpoint theory, which interrogate the notion of objectivity and the backgrounding of the politics that fuel knowledge production (Harding, 1993; Durham, 1998). The embrace of standpoint theory, as discussed in previous chapters, signals the presence of transversal politics as the collective attempts to avoid flattening intersectional positionalities and experiences within the movement.

Journalism professionals working for LatFem, then, are exposing that they are privy to the power dynamics that go into the construction of public discourse and set out to disrupt patriarchal domination by explicitly using the tools of feminist theory. LatFem's (n.d.) mission statement continues: "We propose instead a reflection about our discursive practices [to achieve] an inclusive journalism and intellectual work that is respectful... toward diversity, [gives] especial attention to the voices of victims... and relies on categories of feminist theory." These elements show these media professionals ascribe to gender perspectives developed by feminist journalists in Latin America, which 
directly connects the work and practices at LatFem to Ni Una Menos' efforts to counteract symbolic machista violence.

LatFem focuses on the coverage of domestic violence, femicide, human trafficking, abortion, sexual exploitation, and the issues women face in the workplace. The coverage, then, sheds light on the problems that hinder women from fully enjoying their rights as citizens in democratic Argentina and that threaten women's bodies and lives. The agenda, again, is fully aligned with the broader goals of NUM.

In a news article for LatFem, Agustina Paz Frontera, who is also a founding member of Ni Una Menos, argues against a reform that would significantly decrease house wives and domestic workers' social security entitlements. The reform, Frontera (2017) contends, has a "macho face" in that it effectively targets already vulnerable working-class women, who disproportionately find themselves in need to do precarious work and/or never get paid for the labor they do at home.

Because [the reform] pushes back recently-conquered rights ${ }^{7}$ and because [the reform] builds itself upon the unequal sexual division of labor, which values the work done outside of the home and not the one done in the home, we say that this measure ... contributes to the feminization of poverty (Frontera, 2017).

Here, Frontera (2017) clearly draws from discourses of popular feminists in Latin America and Argentina, who connected the feminization of poverty to neoliberal policies that cut social programs and entitlements to sustain free markets and the incorporation of Latin American economies to global capitalism (Maier, 2010). Frontera (2017) even included a feminist sociology professor as one of her sources to briefly explain the historical process of the feminization of poverty. This way, Frontera's (2017) analysis at

\footnotetext{
${ }^{7}$ In 2005, Argentina passed an Inclusion Plan that allowed millions of women who were out of the formal workforce - i.e. housewives - to collect minimum-wage pensions. The reform Frontera (2017) critiques would cut these pensions in half.
} 
the intersection of gender and class matches LatFem's goal to incorporate feminist theory to the treatment of news.

Like in the digital discourses of Ni Una Menos, LatFem consistently employs the first-person plural throughout its coverage. This foregrounds the fact that the outlet champions a specific standpoint in its articles, challenging the idea and possibility of absolute objectivity in reporting. Furthermore, this practice implies that the reporters have a stake themselves in the development of the news they cover as women, activists, and citizens. Feminist reporters are not only advocating for the rights of their readers, but their own; they are part of the constituency they serve. The website, then, makes explicit the intersection of journalism and activism which links news production to emancipatory efforts. LatFem even communicates that its founders and staff are fully committed to the cause of Ni Una Menos.

We do journalism from a feminist and intersectional perspective and we identify ourselves with the movement $\mathrm{Ni}$ Una Menos ... Our intervention is an assemblage of technologies, social media, and bodies on the streets. Historically, feminists have occupied public spaces to show the world our desires and our opposition to oppression. Today, the occupation of that public space happens within a dialectic between the virtual and what happens on the streets (LatFem, n.d.).

Here, LatFem shows acute awareness about the ways in which the use of digital media technologies shape politics and vice versa. Advancing the objectives of Ni Una Menos, these reporters argue, goes through occupying physical and mediated spaces to transform power relations that cut across and link the discursive and the material. This way, mediated activism is understood as a constitutive part of political activism in LatFem and Ni Una Menos. Consequently, reproducing feminist perspectives and politics in all types of media - digital and traditional, mainstream and alternative - contributes to the goal of eradicating violencia machista, not only in its symbolic dimension. 
Other NUM founding members have also committed themselves to forms of mediated activism to contribute to the work of the collective. In late 2015, Valeria Sampedro and Marcela Ojeda created the podcast "Mujeres de Acá," in English "Women from Here," which airs on Radio Nacional. According to the show's website, the podcast is dedicated to analyses from a gender perspective that question machismo in society and the ways in which it victimizes women. Today, Ojeda describes the show as her "feminist refuge," where she and Sampedro track the status of women's rights in Argentina and push back against injustice (M. Ojeda, personal communication, March 23, 2019). "This is a new militancy that complements other forms. We use media and put the bodies on the street. We must keep conquering spaces” (M. Ojeda, personal communication, March 23, 2019).

This approach to media and reporting goes in line not only with feminist politics, but with visions of "militant journalism" that dominate Argentine journalism practice (Amado Suárez, 2016). While these media professionals do not necessarily ascribe to partisan politics, their reporting is clearly political and militant. This illustrates how feminist journalism dislocates traditional - and mostly Western - understandings of objectivity in journalism practice and of the roles news media professionals get to play in the construction or disruption of public discourses about politics general, and feminist politics in particular. In this context, the figure of the ethical journalist becomes entangled with advocacy practices which require journalists to put their reporting to the service of social justice causes, such as the one championed by Ni Una Menos.

Interventions like the ones discussed in this section foreground the role of mainstream media as a sector of society that, like the state, holds the power to change 
violent narratives and practices. Raising the feminist consciousness in mainstream media is evidently an important step for certain factions of $\mathrm{Ni}$ Una Menos in the eradication of violencia machista. Media workers in the Buenos Aires chapter appear to have made this a priority. The intervention, however, is notably carried out by media insiders who already had access and some ability to enact change in some media organizations. Other chapters of the collective have not targeted or engaged mainstream media in this manner. Due to their position as actual media outsiders, they would not be able to.

Agustina Vilte noted that, in Tucumán, an alliance with local media to curb violence against women would be virtually unthinkable. "Sometimes the media works actively against us. In the case of Belén [the 11-year-old who asked for an abortion], the media even published her real name and her medical records. That is illegal, but they did not care" (A. Vilte, personal communication, April 6, 2019). Because of irresponsible local media coverage, Vilte notes, Belén and her relatives were harassed by pro-life activists and felt endangered.

The mediated activism of the provinces, therefore, take very different forms than the mediated activism in Buenos Aires. Through its Facebook page, NUM Tucumán tries to circumvent media and journalists not to broadcast alternative or radical narratives about their mishandlings of women's issues but to give local women a space to access resources safely. "Every day, I get between two and three new help requests through the group's direct messages. Battered women and women seeking abortions contact us privately because they don't know what to do" (A. Vilte, personal communication, April $6,2019)$. 
Under these circumstances, focusing on a professional and feminist overhaul of media and journalism fall way outside the scope and capacities of regional chapters of $\mathrm{Ni}$ Una Menos. The media activism of NUM Buenos Aires is enabled by the social positioning of the activists in that chapter. They have the language, access and expertise to talk back to the media. Granted, in doing so, these media professionals risk facing symbolic violence and unemployment. However, Vilte's testimony points to sharper power differentials between local activists and media in the provinces as well as to risks far worse than economic instability. This way, the focus of mediated activism in these localities shifts from disrupting symbolic violence to helping vulnerable women weather it as well as other forms of violencia machista. Consequently, social and professional status shape both activists' ability to perform political interventions and the targets of such political interventions.

In the next section, I keep exploring the mediated practices of different chapters of Ni Una Menos and linking them to power relations in the collective. As the findings keep pointing to a faction in the collective taking advantage of non-hierarchical interactivity on social media platforms, it also becomes evident that such features have not granted members of Ni Una Menos outside of Buenos Aires an equal political footing in the movement.

\section{Digital Feminist Media Practices as a Corrective to Violencia Machista}

In this section, I explore how Ni Una Menos employed digital platforms to advance its political goals $\left(\mathrm{RQ}_{2 \mathrm{~b}}\right)$. I argue here that digital platforms and online activism contributed not only to Ni Una Menos' mobilization and conscientization efforts but to the collective's adoption and praxis of transversal politics. Considering the legacies of 
feminist organizing in Argentina alongside the seemingly horizontal interactions that digital communication technologies enabled among founding members of $\mathrm{Ni}$ Una Menos, it is no surprise that NUM ended up embracing collectivist-democratic forms of organizing (Rothschild-Whitt, 1979). It is also true, however, that these online interactions were not totally horizontal - hence the qualifier "seemingly." Consequently, the mediated activism and organizational makeup of $\mathrm{Ni}$ Una Menos derive from complicated and paradoxical histories and technologies that simultaneously open venues for equality and exclusion.

It is undeniably significant that $\mathrm{Ni}$ Una Menos started to make waves on social media. As discussed in previous chapters, by 2015, feminist politics had already a solid footing among a large sector of the Argentine population, including media professionals who either openly ascribed to feminist perspectives or were at least acquainted with the work of feminist and women's organizations nationally and regionally. These professionals had already established networks online; some quite formal and purposeful, such as the PAR network, and some looser that consisted on mutual social media following. When the news about Chiara Páez broke on May 11, 2015, one well-connected journalist went searching for like-minded people who might want to engage in some collective action. Marcela Ojeda indicates that, in her outrage, she thought about the people she had access to. “'What type of women do I have around me that read me?' Businesswomen, writers, journalists... only on Twitter, not in real life. I wrote the tweet there and the exchange began" (Ojeda as cited by Rodríguez, 2015).

The firsts to answer her call were other journalists and feminists in her network. Among them, Ojeda mentions Florencia Etcheves, Soledad Vallejos, Hinde Pomeraniec, 
and Ingrid Beck, women who she had never met in person before. All these women would become founding members of the collective Ni Una Menos a few weeks later. On Twitter, the women decided they would demonstrate on June 3. "There's nothing especial about that date. It was just about convenience for us. That day we could all be off from work" (M. Ojeda, personal communication, March 23, 2019). It was also in these exchanges on Twitter that Beck proposed the name Ni Una Menos to connect the protest to the efforts that feminist organizations had been advancing to address femicide. Beck and others on the Twitter thread had attended the reading marathon called Ni Una Menos that the National Library had put together in Buenos Aires. Beck also knew of the Ni Una Menos Facebook group that had emerged from those events. Florencia Abbate, who coordinated the Facebook group at the time, noted that after establishing an alliance with the Twitter group, the followers of the Facebook page went from a few hundred to hundreds of thousands in less than two weeks (F. Abbate, personal communication, May 5, 2019).

An outpour of support and will for action also manifested on Twitter. People from all walks of life posted selfies holding the \#NiUnaMenos sign and promising to mobilize on June 3. This signaled to the journalists that more organization would be needed. A week after Ojeda's first tweet, around 25 media professionals and women working in feminist and women's organizations decided to meet in person in Buenos Aires to formally coordinate collective action. Mercedes Funes remembers that stepping into action came somewhat naturally to the group: "We reached consensus and, once we divided the tasks, we trusted the others would do their part" (Funes, as cited in 
Rodríguez, 2015). Ojeda indicated that nobody came to the meetings with the idea of establishing an organization or any type of organizational structure.

Emulating decades of feminist organizing in the country, Ni Una Menos came together as a collective committed to "horizontality and transversality" (M. Ojeda, personal communication, 2019, March 23). As noted in previous chapters, the feminist movement in Argentina has a long history of collectivist organizing, which is product of the movement's alliances with the Argentine labor movement. The original members of Ni Una Menos, then, resisted bureaucratic structuring and functioned as a collectivistdemocratic organization. Sociologist Rothschild-Whitt (1979) defines collectivistdemocratic organizations as non-hierarchical structures where horizontal negotiation and consensus among members guide decision-making. In these types of organization, agreement on values and personal relationships between members are key to construct a collective identity (Rothschild-Whitt, 1979). Considering that Ni Una Menos developed a praxis of transversal feminist politics which are rooted on collective values and goals instead of identity or political positionality, the collectivist-democratic mode of organization enabled Ni Una Menos to construct their ideal type of social relationships and practices within the collective.

It could be argued that the structure Twitter sets on interactions through its platform might also have contributed to the non-hierarchical and inclusive perspectives these activists brought to the table in 2015. As the movement started with the organizers engaging in horizontal conversations with one another online, imposing any type of authority would probably have been unnatural. Egalitarian collaboration seemed more 
fitting to this type of online engagement. Now, it is relevant to note that this equality was extended only to those who participated in these seminal conversations and meetings.

Activists from Buenos Aires who had contributed to and connected with the deliberations in Ojeda's thread had a seat at the table in Ni Una Menos. At some point, as many other organizations wanted to join the coordination efforts, the founding members of the collective decided to stop adding people to the group. According to activists quoted in Paula Rodríguez's (2015) book, this was a pragmatic decision, based on the need to make logistics work for the first June 3 march. From then on, the founders would provide broad directives to people who wished to participate on social media. As chapters of $\mathrm{Ni}$ Una Menos organically emerged in the provinces, the activists in Buenos Aires shared the document they had crafted to be read during the demonstration - which would later be labelled as Ni Una Menos' first manifesto. “The idea was to have everyone who was mobilizing with us in other cities reading the document at the same time as us," said Agustina Paz Frontera (Rodríguez, 2015). Apart from these limited contacts and collaborations, the Buenos Aires chapter did not exercise any type of authority over other chapters. Provincial chapters rose on the premise that they were self-sustaining, selfgoverning, and yet connected to Ni Una Menos by the will to end violencia machista and femicide (A. Vilte, personal communication, April 6, 2019).

Collaboration and negotiation among members, then, have been the rule in $\mathrm{Ni}$ Una Menos, apparently allowing its members work through difference and tension. In Paula Rodríguez's (2015) book, many activists talk about a divide within the original $N i$ Una Menos separating those who were focused on promoting the mobilization to the masses by any means available, and those who were pouring feminist and political 
content into the protest. Interestingly, the first group were identified as "las tuiteras" (the tweeters), while the others were "las facebookeras." Las tuiteras were the group of women who met through and started organizing on Twitter. They made the media rounds a priority and activated their contacts to set up the logistics of the demonstration at the lowest cost. This group was more open to allowing high profile public figures mobilize with NUM. In that group was graphic designer Carolina Marcucci, who found it appropriate to embrace all efforts to make the demonstration in Buenos Aires as massive as possible.

Of course, we used all the tools of massive communication... The social networks alone are not enough. The mass media alone are not enough, graphics alone are not enough. What we did was to put all these resources at the service of a cause that was worth it (Marcucci as cited in Rodríguez, 2015).

The nickname las tuiteras, then, seems to do more than just describing the origin of this group. In a show of affinity with the structural characteristics of this social network, las tuiteras seemed to value virality, co-creation, and horizontality. As Twitter enables fast communications and extensive broadcasting, las tuiteras could assemble quickly around a shared goal - the June 3 demonstration - and start collaborating to achieve it.

Las facebookeras, on the other hand, were mostly comprised by feminists of the “old guard" (M. Ojeda, personal communication, 2019, March 23). For Ojeda, this does not mean that this group was out of touch or irrelevant. They had simply been in the political and activist arena longer and had developed more skeptical and cautionary approaches to mass mobilization. It is not a coincidence that they favored Facebook as a social platform. The original Ni Una Menos Facebook group had a content moderator and managed membership to grant victims and relatives of victims a safe space where they could grief and share resources somewhat privately (F. Abbate, personal communication, 
May 5, 2019). This group also hosted feminist activists and NGO workers who managed much of the content and emotional labor in the Facebook group.

From las facebookeras, arguably, came the contents of the protest (Rodríguez, 2015). Considering the heterogeneity that they saw springing from the Twitter group, the facebookeras found a way to articulate much of the transversal approach of $\mathrm{Ni} U n a$ Menos. Fabiana Túñez, then director of La Casa del Encuentro, suggests that a commitment to common objectives instead of partisan politics was key to consolidate collective identity. "We came together under the idea that this was not against anyone or in favor of anyone. From the mobilization, we wanted to generate concrete proposals to challenge the powers that be” (Túñez, as cited in Rodríguez, 2015).

Ingrid Beck, however, indicates that there was not a huge or intractable divide between these groups. Tensions were present, she said, as these groups were not well acquainted to each other before May 2015 and had, therefore, prejudices. However, once more in-person conversations took place and anxieties about partisanship were openly discussed, people were more willing to trust one another (H. Pomeraniec, personal communication April 1, 2019). Furthermore, for Beck, the efforts for mobilization were successful precisely because they never lacked feminist and political content. "We were all necessary and the contributions were multiple and valuable" (Beck as cited in Rodríguez, 2015).

The role of social media in enabling the aforementioned relationships and politics is not negligible. As Tufecki (2017) notes, digital communication technologies, especially social media, allow people to connect with one another based on shared interests and motivations, instead of shared characteristics, such as birthplace, race, 
gender or class status. In digital environments, then, alliances akin to transversal politics are more likely to emerge. As the members of Ni Una Menos first came together online in the pursuit of goals and principles - namely, protest femicide first and then eradicate violencia machista - , continuing to work across difference and ensuring non-hierarchical relations made sense.

Naturally, the fact that some of these activists pertained to legacies of feminist organizing in Argentina also contributed to the collective defaulting to collectivistdemocratic structuring outside digital environments. Shortly after the first June 3 protests, NUM Buenos Aires established a popular assembly system to aid democratic participation of the people in the collective. The assemblies are held in plazas and are open to the public with no restrictions. Promotion for the assemblies happen mostly though social media. Agustina Vilte from Tucumán said the assembly system has been adopted by most of the regional chapters of NUM. "A lot of my Facebook activity [in the NUM Tucumán page] goes into promoting periodical assemblies and posting the agreements we reach in those" (A. Vilte, personal communication, April 6, 2019). Cecilia Palmeiro, member of the collective in Buenos Aires, explained the rationale behind the system as follows:

Organizing in open assemblies guarantees that all voices and bodies matter and that we learn from each other... we must create empathy between us and need to develop a deep understanding of our differences and conflicts. It is crucial that at the same time that we contest the existing order, we create utopias, and put them into practice (Palmeiro as cited in Rodríguez, 2015).

The intention to engage in prefigurative politics is, then, clear within Ni Una Menos. Prefigurative politics comprise the creation of environments in which a group can enact alternative social relations and practices that are deemed more appropriate and less oppressive than the ones society currently subscribes to (Yates, 2015). The existence of 
the assemblies, then, suggests that, as the collective struggles for justice in broader society, NUM attempts to engage in a praxis of justice within its own ranks.

Consequently, avoiding hierarchical relations and exploitative division of labor as well as providing venues for democratic decision-making to women in NUM can be understood another form of political intervention to eradicate violencia machista in Argentina. ${ }^{8}$

Taking attention back to the mediated activism of $\mathrm{Ni}$ Una Menos, it is evident that the digital spaces that the collective has created not only shape but embody its complicated transversal feminist politics. In the previous chapter, I noted that the collective in Buenos Aires welcomed anyone who would support its cause, including controversial public figures. The presence of problematic politicians and celebrities in $\mathrm{Ni}$ Una Menos digital spaces gave activists an opportunity to delve into the complexities of violencia machista and its various manifestations. This shows the collective's intention to work across difference - in identities and political positionality - to advance its goals. However, most of such difference was adopted strategically. As these public figures could expand the reach of the collective and give more dimension to its message, it was acceptable for the activists to make this compromise. As similar incentives for engagement with other chapters of the collective seem to lack, NUM Buenos Aires does not interact much with other chapters online. Apart from expected shout-outs and retweets during national mobilizations from @ColectivoNUM, there is not much online interaction among branches of the collective.

\footnotetext{
${ }^{8}$ These practices, however, should also be critically studied. Such exploration, unfortunately, falls outside of the scope of this dissertation because this virtual ethnography focuses on the relations and practices that take place in digital environments. Methodologies such as fieldwork and participant observation would be required to conduct a valid examination of the full extent of the collectivist-democratic structure and organization of Ni Una Menos.
} 
In the data I collected, I did not observe much significant engagement with other chapters of Ni Una Menos and the localized issues they face. Stronger ties seem to exist with La Campaña por el Aborto Legal, Seguro y Gratuito. As I indicated before, these organizations have campaigned and mobilized together especially in the last two years as La Campaña has tried to pass new legislation in Argentina. Ni Una Menos Buenos Aires has even changed the color pallets of its digital spaces - typically a mix of violet and magenta - to green to reflect its alliance with the pro-abortion movement. Other chapters of the collective have not followed suit in their Facebook pages or Twitter accounts.

The mediated activism of NUM Buenos Aires seems more connected to and fueled by cross-organizational and, moreover, cross-national networks than by relationships with other chapters under the same name and cause in Argentina. The website niunamenos.org.ar links the Buenos Aires chapter to intersectional and transnational feminist understandings by sharing the works of feminist authors from across the globe, such as bell hooks, Patricia Hill Collins, and Gloria Anzaldúa. In the Resources tab of this website, NUM Buenos Aires gives free access to books and articles by Argentine and international as well as Black, queer and Indigenous feminists who nurture the feminist perspectives of the movement.

The deep involvement of this chapter in the coordination of the International Women's Strike in 2017 also exemplifies the international investments of NUM Buenos Aires. Thanks to social media, members of Ni Una Menos Buenos Aires ${ }^{9}$ joined forces

\footnotetext{
${ }^{9}$ I found no evidence in the data suggesting that activists from other Argentine provinces were directly involved in the organization of the international strike. Many regional NUM chapters participated in the strike; however, I did not see any explicit reference to them in the coordination efforts. There were only references to Ni Una Menos as a whole. Considering the described practices and positionalities of the Buenos Aires chapter, I assume that only Buenos Aires activists participated in this global initiative.
} 
with other feminist organizations in Poland and the United States to organize the International Women's Strike of 2017. To promote the strike, American Black and queer feminist scholars, including Linda Martín Alcoff, Tithi Bhattacharya, Nancy Fraser, Keeanga-Yamahtta Taylor, and Angela Davis, published a manifesto in The Guardian stating the objectives of the strike and praising the transnational nature of the effort. They credited Ni Una Menos for contributing perspectives that resisted neoliberal violence and co-optation: "In embracing a feminism for the $99 \%$, we take inspiration from the Argentinian coalition Ni Una Menos" (Alcoff et. all, 2017).

This text is definitely the result of transnational solidarities among networked feminists struggling against the push of liberal and potentially racist forms of feminism. I will not argue against the positive outcomes of such alliances and how they might give a movement like Ni Una Menos more power to affect positive change in its own context. It is difficult, however, to determine who exactly gave inspiration to the Americans. Do they talk of Ni Una Menos, the federal coalition of chapters that includes the capitol, or NUM Buenos Aires? Which $99 \%$ is getting visibility and power here? An international 99\% - with Argentina being a token for the global South? Or an intranational 99\% - with minoritized and marginalized peoples in each state being centered?

The implications of each understanding of the $99 \%$ lead to different implications. On the one hand, this can be another instance of transnational solidarities that unintentionally render invisible and unproblematic the dominance of the United States (Fernandes, 2015). These solidarities emerge among those with enough privilege to communicate and articulate politics in digital environments that cut through geographical boundaries. On the other hand, this manifesto could be a truly radical statement to get the 
networked privileged to advocate for and empower those dwelling the most vulnerable intersections of transnational power. With the data I have, I cannot privilege one interpretation over the other. I can only point to this thought-provoking ambiguity.

In the following section, I present a brief discussion about the findings I have exposed in this chapter.

\section{Media, Digital Communications, and Politics: Co-Structuring Fields}

In this chapter, I have examined the complex entanglements between the transversal feminist politics of Ni Una Menos and the media. The findings illustrate how the uses and experiences of media - traditional and digital - influence the grievances of social movement constituencies as well as the structure and activism of the organizations that conduct politics around those grievances. Simultaneously, the politics that define these organizations shape their media uses and practices, as these can become spaces for prefigurative politics where movements can enact social relations and arrangements they deem ideal (Yates, 2015).

The first section of the chapter delved into the ways in which mainstream media representations and news coverage of women and women's issues contributed to the sense of risk and vulnerability that Ni Una Menos activists resist. In line with Argentine and international legal frameworks, symbolic violence was on the radar of NUM as a form of violencia machista. As many activists of NUM Buenos Aires are media professionals, they were sensitized and sensitive to the structural and editorial challenges mainstream media posed to the incorporation of gender and feminist perspectives that could render vindications for women. The activists turned to digital media to denounce gender disparities in Argentine newsrooms as well as instances of negligence in 
reporting. Furthermore, the activists interrogated the exploitative practices of news media outlets which constantly asked feminist media workers for interviews or low-pay freelance work without opening positions to fully and consistently incorporate a gender perspective in their coverage. In this context, some members of the Buenos Aires chapter even created their own feminist digital news outlet to showcase the type of journalistic practices and content they advocate for.

These mediated discourses and practices targeting mainstream media evidently aim to challenge and displace the cultural and structural dominance of machismo. As seen in previous chapters, Ni Una Menos considers femicide and rape to be extreme manifestations of violencia machista which are ultimately rooted in subtler and more naturalized violent practices, including symbolic violence. Considering that mainstream media is one of the main producers and carriers of culture and meaning, disrupting harmful gender representations and practices in mainstream media is an important step in curbing the deadly forms of violencia machista.

In its mediated discourses, Ni Una Menos Buenos Aires also championed other cultural interventions outside media institutions, such as the implementation of programs for integral sex education and the exclusion of religious-based teachings from the public education system. The campaigns for the legalization of abortion could also be taken as an effort to legally codify a cultural shift in the understanding of female sexuality and agency. These interventions signal the collective's need to address the hegemonic nature of machismo as a precondition to addressing the violence that springs from it. Taken together and in the broadest sense, these political initiatives provide society with an alternative vision of sexuality and gender relations that reject chronic female 
objectification, compulsive sexual conservatism and the political disenfranchisement of women. As Downing (2001) conceptualized it, Ni Una Menos engages in counterhegemonic discourses and practices through its radical media, which shows the relevance of mediated discourses and activism in the resistance.

Such challenges and disruptions to mainstream media, however, were specific to NUM Buenos Aires. As activists in the provinces do not enjoy the same levels of media access and expertise, the mediated activism of other $\mathrm{Ni}$ Una Menos chapters is not focused on the advancement of feminist narratives, principles, or correctives. Social media posts centering these themes are usually reposts of content coming from the accounts of Ni Una Menos Buenos Aires. Instead, the case of NUM Tucumán seems to illustrate that the priority of other chapters is to provide practical assistance to women who are victimized by violencia machista. The private channels embedded in the chapters' social networks provide a safe space for local women to seek help and guidance without compromising their privacy. In more hostile material and mediated environments and without the professional tools to affect media from within, NUM activists in the provinces engage in different relationships and conflicts with mainstream media.

The second section of this chapter explored how Ni Una Menos employed mediated activism and created radical media in digital spaces to exercise and shape its transversal feminist politics. The findings suggest that horizontal and non-hierarchical interactions enabled by social media platforms contributed to the configuration of collectivist-democratic forms of organizing within the collective. Furthermore, as social networks facilitate the assemblage of people based on interests and motivations instead of 
identities (Tufecki, 2017), the structure of social media interactions might have also help in the formation of NUM's transversal approach to feminist politics.

However, it would be a mistake to credit only the connective and participatory capacities of social networks for the organizational structure and political approach of $\mathrm{Ni}$ Una Menos. In the words of Natalie Fenton (2016), "politics and political organization emerge from histories that do not evaporate in the face of technology" (p. 119). The organizational arrangements and politics Ni Una Menos adopted find a solid footing in the history of feminist organizing in Argentina and Latin America, where labor and leftist collectivist-democratic organizations influenced the structure of feminist coalitions. As seen in the findings, NUM founders were acquainted with these histories. Therefore, these historical referents informed Ni Una Menos' approach to mediated activism, allowing the collective to gravitate toward transversal discourses, non-hierarchical organizational arrangements and democratic procedures for participation. Marcela Ojeda argued that, while social media enabled rapid communication and coordination of protest in 2015 and after, digital technologies only complemented existing forms of feminist militancy in Argentina. "On social media one can agitate, invite, and share, but you also must materialize it at some point. For that, you must embrace a flag, a history" (M. Ojeda, personal communication, March 23, 2019). It is, then, in the materialization of goals where the core of the politics lies.

By noting this, I'm not entirely brushing off the contribution of new communication technologies to the structuring and politics of the collective. Instead, I argue for a contextualized understanding of the mediated activism of this collective, which borrowed its shape from previous forms of activism. As Ni Una Menos' mediated 
activism was first informed by these histories, its media discourses, organization and practices reproduced and adapted those histories in the digital media environment.

When thinking of alternative media, Atton (2002) argued that they offer "the means for democratic communication to people who are normally excluded from media production" (p. 4). Members of NUM Buenos Aires have critiqued the lack of feminist and women's voices in mainstream media. Considering that media in Argentina demonstrably reproduces symbolic violence against women, and sports majority-male newsrooms with majority-male media executives, the denunciations of these activists are definitely based on a problematic reality. However, it is necessary to interrogate these grievances as they come from a sector of $\mathrm{Ni}$ Una Menos already endowed with some media power: middle-class women who are media professionals.

Tufecki (2014) argues that, when evaluating the media practices of social movements, it is necessary to pay attention to the factors that give a group the agency and capability to carry out political acts. As seen in previous chapters, the founders of $\mathrm{Ni} U n \mathrm{a}$ Menos in Buenos Aires were mostly professional women with ties to the media and feminist organizations. These activists used their existing networks not only to give media exposure to the collective's interventions but to articulate a politics that resonated with the history of the feminist movement in the country and the political and technological moment Argentina was in.

The mediated spaces created by NUM Buenos Aires, as described before, are tinted with professionalism. The chapter's website showcases design features that contribute to a positive user experience, such as non-disruptive backgrounds, browsersafe colors, consistent navigation throughout the website, fast-loading pages, and 
responsive design. The social media accounts of the capitol chapter use the same color pallets as its website and showcase consistent discursive patterns and style in their use of hashtags, pictures, video, and mentions. The digital news outlet LatFem shares some of the layouts and aesthetics of niunamenos.org.ar, signaling the link between these platforms. Considering the networks and competencies of the NUM Buenos Aires activists, it would not be a surprise that the digital presence of this chapter has been carefully built and curated by a volunteer team of journalists, graphic designers and web developers.

These design features along with the media and political power the Buenos Aires group has, gives more prominence to this chapter in digital environments. Furthermore, as some of its members have had much media exposure through their media work and activism, the visibility of NUM Buenos Aires increases. In comparison, the social networks of the provincial chapters cannot compete. Agustina Vilte of NUM Tucumán notes that the position and prominence of NUM Buenos Aires is positive in that it has given more visibility to the issue of violencia machista and the national fight for the legalization of abortion. However, she said, the influence of Buenos Aires renders invisible the localized struggles of women in the provinces.

Something way too big has to happen here for Buenos Aires to pay attention. That's how it has always been. Ni Una Menos Buenos Aires is not changing that much. Anybody can open a chapter in their town, and that is good. But our issues also deserve national attention (A. Vilte, personal communication, April 6, 2019).

The political centrality of the Argentine capitol and its people, then, has shaped the relations within Ni Una Menos just as it has shaped politics in Argentina in general. As Hinde Pomeraniec argued, socioeconomic and geographic divides challenge the feminist movement as it tries - and sometimes fails - to render visible the struggles of the most 
vulnerable sectors of the population and effectively advocate for them. Communication technologies and radical media spaces online have given a window to some activists and citizens to circumvent traditional gatekeepers of information. However, inequities inherent to class stratification, professional background and networks, and geographical location still impact the ability of people to not only access and use communication technologies but to utilize them politically in an effective way. As structural obstacles prevent effective and intersectional advocacy across the board, the challenge to achieve justice for all remains.

This chapter shows, then, the complicated entanglements between political formations and mediated discourses and practices. As much as movements and organizations such as $\mathrm{Ni}$ Una Menos attempt to engage in prefigurative transversal and democratic politics in its mediated spaces, historical patterns of political domination sneak in the relations, practices, and objectives that link diverse constituencies under a movement's flag. The success of the Buenos Aires group in gaining visibility has not reached the whole range of the collective. Furthermore, as this NUM chapter increases its political pull and media profile, the chances of regional chapters of getting attention shrink and become more dependent on hyperbolical occurrences that can lend themselves to media spectacle. Digital communication technologies, so far, have not alleviated these disparities but aided them, giving media savvy activists from Buenos Aires more tools to articulate their political demands nationally and internationally, risking the invisibilization of the struggle of other chapters and constituencies. To level the playfield, and achieve the justice it has defined, Ni Una Menos might need to start looking inward. In the next chapter of this dissertation, I present the conclusions of this case study. 


\section{CHAPTER SIX: CONCLUSION}

On April 9, 2019, feminist philosopher Judith Butler visited Argentina to participate in a conference organized by the Universidad Tres de Febrero in Buenos Aires. Butler was set to join Marcela Fuentes, Vanina Escales, Agustina Paz Frontera and María Florencia Alcaraz, members of Ni Una Menos Buenos Aires, in a panel called “Activism and Thought." The philosopher answered the activists' questions about transnationalism, intersectionality, and conservative backlash against feminist movements. Excerpts of this interview were later transcribed and published in English at LatFem, where all the above listed NUM activists work. The second question of the interview reads as follows:

Do you think that movements like Ni Una Menos can become imperialist practices? How can a movement inform mobilizations happening in other places without disregard [sic] to local specificities or using the category of "woman" in universalist terms? In that regard, why do you think the US has been slow in taking up the lead of women's and feminist movements happening around the world? (“Judith Butler," 2019).

My first reaction to the question was awe. It was impressive to see these journalists speaking the language of Butler. To be clear, by this I do not mean English. I refer to the activists' polished use of the language of feminism. Academic feminism. An understanding about the arguments of post-structuralist and transnational critical theories clearly undergirds this question. The level of reflexivity here is also remarkable, as movements need to keep themselves in check as they gain the type of political pull $\mathrm{Ni}$ Una Menos currently enjoys. The activists even subtly incorporated some... shade when asking about the status of American feminism vis-à-vis feminist movements in other locations. The graduate student in me could not be prouder. 
Later, I worried about my veiled condescension. Why would these activists not be well-versed in post-structuralist and transnational feminism? They have been pouring feminist theory and praxis in their work as activists and journalists for at least four years now; so, what is the surprise? Such amazement could only come from a quiet and deeplyrooted doubt about the intellectual and political capacities of Argentine feminists. Thank you for your contributions, colonization. I will keep the unlearning going.

As I was recuperating from my colonial shame, the Butler interview brought out other concerns. The question about imperialism, especially, started to make me cringe. The inquiry per se was not the problem. Any ethical movement sporting some level of transnational awareness must pose this question. What bothered me was who the question was directed to. The irony of asking a white American about the dangers of imperialism is too on the nose. Butler, however, in line with her feminist history, offered a thoughtful answer. They indicated that imperialist thought can silently creep in any movement, as the vanguards impose hierarchies and undermine democratic reform. Butler's prescription to prevent this phenomenon is to have the movement's leadership "continue to listen to its critics, invite them into conversation, stay present for the conflicts, and be willing to change its vocabulary and its practices when it proves to be exclusionary" ("Judith Butler," 2019).

In a way, Butler suggests that this problem, if it exists, is not for Butler to solve. If this exchange emerged from - conscious or unconscious - anxieties about possible imperialist practices within Ni Una Menos, then the question should not be directed to Butler. It should be directed to someone like Agustina Vilte or any of the NUM activists operating outside of Buenos Aires. This is a question for Indigenous, Black, trans, queer, 
impoverished, and migrant women in Argentina to answer. Were these marginalized constituencies of $\mathrm{Ni}$ Una Menos even present at this panel? If they were, they did not get to share the stage with Butler. I scowl at the computer screen. Don't you see that a fellow privileged professional feminist born in an actual imperial power is not in the best position to keep anyone's colonial tendencies in check?

I cannot say with certainty that these discussions do not happen in the assemblies of Ni Una Menos. Maybe they do. However, Butler's visit to Argentina and her exchange with the Buenos Aires chapter of the collective illustrate the complexities that underlie and potentially undermine emancipatory feminist efforts. Even when movements explicitly attempt to incorporate intersectional and transversal politics to level the playing field, structural and material inequities hinder profound and sustainable transformation of relations of power and oppression.

This dissertation aimed to examine how mediated discourses and activism along with histories of national and regional feminism were co-constitutive forces of the politics of Ni Una Menos. By putting in conversation existing literature on mediated activism, social movements and feminism, it became evident that the advent of the Internet and digital communication technologies had shifted approaches to and practices of oppositional politics (Waisbord, 2018). While opportunities for global connectivity, participation, and broadcasting became available to agents outside governments and traditional media, inequities structuring societies also appeared structuring the flows of power in digital environments (Tufecki, 2017). Analyses that take into consideration the political economy of the Internet have noted that the ability to advance politics online is not equally distributed among all. Not everyone can use the Internet politically, and this 
is not only an issue of access. People who successfully articulate politics in digital environments engage technical and political competencies and networks to craft messages as well as build identities and coalitions online and offline. Consequently, the political uses of the Internet are usually exploited by sectors who are already afforded with some level of privilege (Fenton, 2016).

Furthermore, postcolonial and transnational feminist scholars have noted that power differentials between the West and the Rest shape the production and distribution of knowledge in a way that contributes to the silencing and/or vilification of marginalized voices in the so-called Third World (Mohanty, 1986). Communication technologies are not isolated from this phenomenon. Fernandes (2013) noted that the structure of globalized communication networks imposes imperial regimes of visibility that focus global attention on locations and occurrences that reinforce the cultural, moral and military domination of the West. Consequently, discourses and forms of resistance that are compatible with Western neoliberal ideals of individualism, consumerism, citizenship and development garner more exposure on digital networks. Such visibility, however, can derive in the trivialization and commodification of the movement. Therefore, as movements articulate their oppositional politics online, they risk the co-optation and depoliticization of their cause.

In the case of $\mathrm{Ni}$ Una Menos, the power imbalances structuring material and mediated spaces influenced the discourses, politics, and mediated activism of the collective since its inception in 2015. In chapter four, I examined how Ni Una Menos defined its politics and collective identity in its online discourses. The findings suggested that $\mathrm{Ni}$ Una Menos embraced a structural and broad conceptualization of violencia 
machista to enable advocacy for the grievances of intersectional constituencies. By constructing violencia machista as a multifaceted instrument for the political domination of women, Ni Una Menos could engage simultaneously in diverse struggles for women's liberation, such as the legalization of abortion, educational reform, LGTBQ and indigenous rights, etc. These flexible solidarities (Collins, 2017), while incorporating tension among members of the collective who had different identities and political positionalities, did not severely compromise their sense of belonging to the collective. Consequently, the online discourses of Ni Una Menos signal the collective's embrace of transversal politics (Yuval-Davis, 1999), which gave activists a platform to advocate across difference without flattening intersectional experiences of oppression.

An examination of the mediated activism of $\mathrm{Ni}$ Una Menos, however, exposed more complex power dynamics within the movement. In chapter five, I covered how the collective used mediated activism to shape and advance its transversal feminist politics. I found that NUM Buenos Aires, as compared to other chapters, engaged in mediated practices that boosted its status in both the national and digital media arena. Since this chapter is mostly constituted by media professionals, NUM Buenos Aires could at times build symbiotic relationships with mainstream media, succeeding in incorporating $\mathrm{Ni}$ Una Menos and its cause in the media agenda. Of course, the chapter maintained a critical stance toward the problems mainstream media reproduced regarding violencia machista, namely their participation in symbolic violence against women, male overrepresentation in newsrooms, and the lack of gender perspectives in news reporting. Nevertheless, NUM Buenos Aires, because of the professional status of its members, could engage with media as insiders, making the articulation and distribution of messages 
easier in traditional and digital platforms. Despite the positive outcomes of these relations with mainstream media, fundamental feminist reform of the media industry has not yet happened.

Other chapters of Ni Una Menos, on the other hand, did not count with the networks and expertise to create productive or promising relationships with mainstream media. In provinces like Tucumán, local media has engaged in openly hostile discourses and practices against women victimized by violencia machista. Agustina Vilte's testimonies and anecdotes suggest that, unlike in Buenos Aires, media in the provinces have been even less responsive to activists' calls for feminist reform and acted in alignment to their veiled partnerships with conservative factions of political and religious life. Therefore, the mediated activism of provincial $\mathrm{Ni}$ Una Menos chapters focuses more on providing victims and their relatives with spaces where they can bring up their issues and fulfill their needs without risking their right to privacy.

These different political environments for and approaches to mediated activism in Ni Una Menos have contributed to the hypervisibility of the Buenos Aires group in digital spaces. While the digital presence of many provincial chapters is merely functional and relatively rudimentary, the digital presence of NUM Buenos Aires showcases superior intellectual and aesthetic sophistication. Furthermore, this chapter does not identify its digital spaces and content as representing the positions of one NUM chapter but of the whole collective. Consequently, when there are conversations about the initiatives of $\mathrm{Ni}$ Una Menos in Argentina, the conversations usually entail the initiatives of NUM Buenos Aires. The ability of Buenos Aires activists to exploit professional networks and digital 
media competencies, then, allowed them to have a much more prominent position in the movement, rendering other chapters virtually invisible in digital environments.

These findings resonate with the observations of scholars like Natalie Fenton (2016), who has noted that middle- and upper-class constituencies have the upper-hand when it comes to utilizing new communication technologies for political purposes. The cultural and social capital these constituencies possess enable them to effectively engage digital and political competencies necessary for success. All things being equal, marginalized and minoritized constituencies cannot compete with more privileged voices even if they pertain to the same movements. Consequently, the findings of this dissertation support theorizations of media power that consider media to be a structuring element that informs not only the political expression of movements, but their organizational structure and even the targets of their political activism (Waisbord, 2018; Couldry, 2003). Now, this structuring role of the media in the constitution and development of social movements is in no way isolated from the historic politics and grievances that shape the material realities societies dwell. As Friedman (2017) argued, media practices and politics are mutually constitutive forces in the context of political activism.

In the case of $\mathrm{Ni}$ Una Menos, power differentials shaping the professional background, geographic location, and digital and political competencies of their members structured the hierarchies within the collective. As a social movement organization, $\mathrm{Ni}$ Una Menos, following long histories of feminist and labor movements in Argentina, adopted a collectivist-democratic structure (Rothschild-Whitt, 1979) to match its transversal politics. Theoretically, at the core of collectivist-democratic organizations 
there is a deep commitment to non-hierarchical relations and democratic and horizontal processes of decision-making. In praxis, however, the collectivist-democratic structure and the commitment to transversal feminist politics did not prevent privileged members of Ni Una Menos in Buenos Aires to gain more prominence within the movement. While each chapter of Ni Una Menos, including NUM Buenos Aires, has internally established an assembly system to coordinate collective action, there seems to be no system in place - collectivist or otherwise - to ensure consistent political coordination and support among chapters. This way, the political expertise and pull remain concentrated in the Argentine capitol.

Granted, under the umbrella of Ni Una Menos, all chapters fight for the eradication of violencia machista. However, the chapters operate so independently that the only "coordinated" actions occur on June 3, the anniversary of the first NUM demonstration, and March 8, date of the annual international women's strike. On the bright side, this relative disconnection might allow chapters to focus exclusively on the issues that affect their own localities. The downside, nevertheless, manifests when considering the uneven distribution of political and mediated resources and competencies across the board, which make the dominance of the Buenos Aires chapter possible. The successes of NUM Buenos Aires in the feminist movement and in national politics, as seen in the findings, do not necessarily trickle down to improve the conditions of more vulnerable women in the provinces.

These complicated dynamics invite further explorations of the implications and complexities of transversal politics. As defined by Yuval-Davis (1999), transversal politics have the potential to help movements consolidate coalitions across difference 
without flattening diverse experiences of oppression. The concept of flexible solidarities (Collins, 2017), which enables intersectional alliances without compromising core values, opens possibilities for creative and sophisticated political engagement based on relations of compromise and contestation. However, the case of $\mathrm{Ni}$ Una Menos illustrates that, even when movements incorporate transversal politics to their advocacy, the principle of equality in difference (Yuval-Davis, 2003) can still be compromised by the same dynamics of power and oppression movements might try to disrupt.

Intersectional identities and socio-political positionings always already shape the structures and flows of power in movements, allocating different privileges and vulnerabilities among diverse members of social movement organizations. When it comes to Ni Una Menos, the political supremacy of Buenos Aires along with the superior professional competencies and networks of the activists operating in the Argentine capitol, afforded NUM Buenos Aires a protagonist role in the collective. Chapters in the provinces do not have the resources or expertise to bring the same type of attention to their local grievances and agendas, which compromises their ability to advocate for the rights of women who are in much more vulnerable positions than those in Buenos Aires. As the Buenos Aires chapter garners more national and international political pull, marginalized and minoritized women in Argentina might be further pushed to the margins. While the structural and material conditions that account for difference are not addressed and corrected, the equality in difference principle that transversal politics conceptually upholds is nothing but a discursive trope.

Now, it is true that Ni Una Menos, including NUM Buenos Aires, does advocate for the dismantling of systems of oppression and political domination that render women 
in many positionings "different" or, more specifically, disadvantaged. As seen in this dissertation, the collective has been successful in identifying how the pervasiveness of violencia machista makes the lives of women precarious in all sorts of private and public spaces. Furthermore, Ni Una Menos has employed feminist theories and politics to propose and enact transformations in key social institutions. However, considering the mediated practices and power dynamics within the collective, $\mathrm{Ni}$ Una Menos has not yet found ways to distribute power and visibility equally among the intersectional constituencies it claims to serve.

Considering that the professional background of members of NUM Buenos Aires gives this chapter much of its political edge, these activists could engage in internal educational initiatives to alleviate the power differentials within the collective. For instance, members who are media professionals could develop workshops to teach other members how to better take advantage of the connective and participatory features of social media to improve the digital presence of regional chapters. Additionally, the websites niunamenos.org.ar and latfem.org.ar, currently run by members of NUM Buenos Aires, could also incorporate content by members of other chapters of the collective that delve into the local struggles and efforts of women in the provinces.

Apart from these mediated solutions, Ni Una Menos could tweak its organizational structure to improve cooperation among the branches of the collective. The assembly model that each chapter of $\mathrm{Ni}$ Una Menos has adopted in line with their collectivist-democratic structures could become extended to ensure consistent and open communications among all NUM chapters. If representatives from each regional chapter, including Buenos Aires, met regularly to share concerns and resources, the collective as a 
whole could develop sustainable strategies to ensure that no region in Argentina is left behind in the pursuit of the eradication of violencia machista.

\section{Methodological (Re)Considerations: Limitations and Suggestions}

Considering that most of the findings in this dissertation draw from the analysis of data obtained exclusively in digital environments, further exploration is needed to fully understand the victories and flaws of the transversal feminist politics of Ni Una Menos. To better situate the findings of this dissertation, I offer in this next section a brief discussion of the methodological shortcomings of my study, along with some recommendations for researchers who might want to engage virtual ethnographic work in their case studies.

Additional studies employing other methods of data collection and analysis would be needed to produce deeper and clearer understandings about the complex innerworkings of this collective. As Hine (2000) indicated, virtual ethnographies are inherently partial as they miss much of the material conditions that shape the digital environments and communication practices that define online communities. To this accurate assertion, I would add that virtual ethnographies are inherently confusing. It is challenging to know for certain which interactions in which digital spaces are relevant to describe and explain an online community. Social media metrics such as likes, shares or retweets do not contribute much to developing criteria for categorizing digital content. Digital environments and interactions are intricate and do not by themselves explain the conditions that shape them.

Many times, offline sources are the ones that provide a better sense of direction. I found that digging into the history of the collective was the most effective way to track 
meaningful content, sites, and interactions online. After finding Paula Rodríguez's oral history of Ni Una Menos, I could search for the social media accounts of the founding members of the collective. Furthermore, a lucky encounter with a University of Missouri professor and activist who is well acquainted with some NUM members in Buenos Aires allowed me to narrow down my searches and obtain some personal contact information.

Navigating and engaging with the digital spaces of Ni Una Menos was still challenging from a research standpoint. Although I could consistently track the online discourses and interactions of key accounts and sites, it was challenging to find meaningful ways of engaging with members of $\mathrm{Ni}$ Una Menos online. Considering that the digital discourses and practices of $\mathrm{Ni}$ Una Menos are mostly geared toward collective action and deeper political engagement, not having access to the offline spaces where the actions were taking place made it virtually impossible for me to form a solid sense of belonging, as ethnographic works - virtual and traditional - encourage.

To control for this methodological limitation in this case study, I conducted indepth interviews with former and current members of $\mathrm{Ni}$ Una Menos. Recruiting from afar brought its own problems. I employed email, the public and private features in social media, and even text messages. Out of 20 activists I contacted multiple times through multiple mediums, only four responded and participated in the study. The first of them, Marcela Ojeda, was especially challenging to schedule. We texted back and forth for two days through the direct messaging app WhatsApp before she accepted to participate. At times it felt like she was testing me and my interest in Ni Una Menos. The process of convincing Ojeda showed me how difficult it is to establish trust and credibility through a screen. Once I interviewed Ojeda, she vouched for me with other Ni Una Menos activists 
in Buenos Aires, which landed me two more interviews. Getting participants from the provinces was different. The only way I could establish contact with many of them was through Facebook. I used the direct message feature to make general calls for participants in six chapters. Only Agustina Vilte from Tucumán replied. Her interview turned out to be key to situate the findings of this dissertation.

This data was indeed useful for me to appropriately contextualize and interpret some of the interactions and practices I was observing as part of the virtual ethnographic fieldwork. However, as these were long-distance interviews, my ability to situate the testimonies of the participants was as well limited. Many complexities go unnoticed or unexplained when one conducts research only in digital environments. Prolonged inperson contact with participants is more conducive to deeper assessments of interview responses. Accompanying the activists in their day-to-day work would have been instrumental to observe and assess the participants' positions and practices in the collective. Comprehensive observation and fieldwork would be needed to examine relationships and power dynamics in Ni Una Menos. Consequently, I recommend complementing the findings of this work with traditional ethnographic fieldwork and participant observation to better describe and explain the case of $\mathrm{Ni}$ Una Menos.

Future research into this case, therefore, could take these other methodological approaches as a starting point to advance knowledge about this collective and transversal feminist politics. Considering the findings of this dissertation about the relations among various Ni Una Menos chapters, upcoming studies would benefit from collecting and analyzing data from Argentine provinces. An embedded multiple case study design (Yin, 2017) would allow researchers to investigate the issues and power dynamics that connect 
and disconnect the branches of Ni Una Menos. In doing so, a holistic understanding of the case would emerge.

\section{Closing Reflections about the State of Ni Una Menos (Buenos Aires)}

The complicated entanglements between mediated practices and material conditions challenge the ability of social movements to enact progressive change. As much as digital technologies enable new forms of activism, its structures still favor the political expression and action of privileged sectors of the population. Those who do not count with the resources and knowledge to take full advantage of the connective and participatory capabilities of digital platforms are still, invariably, left behind. Ni Una Menos, despite its intention to engage in collectivist, transversal and intersectional feminist politics, has not been entirely successful in foregrounding and empowering all women, especially the most vulnerable ones.

Perhaps this is an unfair expectation. The inequities that permeate Ni Una Menos are the result of histories of colonial, racist, ableist, patriarchal, heteronormative, homophobic, transphobic, and xenophobic systems of power that have constituted nationstates such as Argentina. The transformation of these systems is on the hands of the state and civic society, and such transformations are in many cases dependent on generational change. There are no clear paths or guidelines for these undertakings, and the odds are not always in the activists' favor. Social movements cannot single-handedly fix all problems or even create ideal worlds in the confines of their own organizations.

What can be expected from Ni Una Menos, especially NUM Buenos Aires, is reflexivity and flexibility to adjust. The findings of this dissertation have shown that the activists in the Argentine capitol have gained too much prominence, rendering both 
positive and negative outcomes. While their knowledge and media savviness have popularized feminist politics in Argentina and identified the challenges violencia machista poses even internationally, NUM Buenos Aires is not opening spaces for marginalized and minoritized women in Argentina. The chapter does not address the disparities of power inside its own networks, allowing the same already empowered voices to keep articulating the politics of the collective. Members of NUM Buenos Aires might already be noticing that its power may be getting out of hand. I strongly believe that the questions to Butler come from a place of genuine internal concern. Butler recommended to listen and adjust. For them, a good next step could be to take the passenger's seat, putting their media acumen and networks at the service of activists in the provinces. Sometimes the most revolutionary thing to do once you have set up a movement is to go quiet and pass the mic.

The case of Ni Una Menos illustrates the complex realities that social movements navigate in their political and mediated praxis. Even when movements aim to achieve equality and justice, their prefigurative politics are still shaped by the same inequity that structures the societies that host these movements. The path to liberation is, therefore, as complicated as the realities social movements aim to disrupt. In the end, only one thing is absolutely clear: Social justice is messy. 


\section{REFERENCES}

Abu-Lughod, L. (1990). Can There Be a Feminist Ethnography? Women and Performance: A Journal of Feminist Theory, 5(1), 7-27.

Alcaraz, M. F. (2017, February 3). Medios sin mujeres. Nuestras Voces. Retrieved from: http://www.nuestrasvoces.com.ar/vivir-bien/medios-sin-mujeres/

Alcaraz, M. F. (2019, January 22). Argentina: Femicidios de Estado. Nodal. Retrieved from: https://www.nodal.am/2019/01/femicidios-de-estado-por-florencia-alcaraz/

Amado Suárez, A. (2012). Periodismo argentino: en busca de datos sobre la profesión. Austral Comunicación, 1(2), 113-135.

Amado Suárez, A. (2016, October 18). Country Report: Journalists in Argentina. Worlds of Journalism. Retrieved from: https://epub.ub.unimuenchen.de/29696/1/Adriana_Amado_Country_report_Argentina.pdf

Andelsman, V., \& Mitchelstein, E. (2019). If it Bleeds it Leads: Coverage of violence against women and sexual and reproductive health in Argentina from 1995 to 2015. Journalism Practice, 13(4), 458-475.

Andersen, M. E. (1993). Dossier secreto: Argentina's desaparecidos and the myth of the “dirty war.” Boulder, CO: Westview.

Atton, C. (2002). Alternative Media. Thousand Oaks, CA: Sage Publications.

Barrancos, D. (2007). Mujeres en la Sociedad Argentina. Una historia de cinco siglos. Buenos Aires, Argentina: Sudamericana.

Basu, A. (1995). The Challenge of Local Feminisms. Women's Movements in Global Perspective. San Francisco, USA: Westview Press.

Baxter, J. (2003). Positioning gender in discourse. London: Palgrave. 
Becerra, M. \& Mastrini, G. (2010). Crisis, What Crisis? Argentine Media in View of the 2008 International Financial Crisis. International Journal of Communication, 4, $611-629$.

Bellotti, M. (2002). 1984-1989: El Feminismo y el Movimiento de Mujeres. En El Feminismo y El Movimiento de Mujeres. Una contribución al debate. Argentina 1984-1989. Buenos Aires, Argentina: Centro de Documentación sobre la Mujer.

Bennett, W.L. (2003). New Media Power: The Internet and Global Activism. In N. Couldry, \& J. Curran (Eds.), Contesting Media Power: Alternative Media in a Networked World, pp. 17-38. Maryland: Rowman \& Littlefield Publishers.

Bordt, R. L. (1997). How alternative ideas become institutions: The case of feminist collectives. Nonprofit and Voluntary Sector Quarterly, 26(2), 132-155.

Brenner, J. (2003). Transnational feminism and the struggle for global justice. New Politics, 9(2), 26-34.

Buch, E.D. \& Staller, K.M. (2014). What is feminist ethnography? In S.N. Hesse-Biber (Ed.), Feminist Research Practice: A Primer, pp. 187-221. Thousand Oaks, CA: Sage.

Carastathis, A. (2016). Intersectionality: Origins, Contestations, Horizons. Lincoln, USA: University of Nebraska Press.

Castells, M. (2012). The rise of the network society (Vol. 12). John Wiley \& Sons.

Castells, M. (2015). Networks of Outrage and Hope: Social Movements in the Internet Age. Cambridge, U.K.: Polity Press. 
Centenera, M. (2019, February 20). La campaña en favor del aborto legal en Argentina se relanza con un nuevo 'pañuelazo.' El País. Retrieved from: https://elpais.com/sociedad/2019/02/19/actualidad/1550608297_024470.html

“Charter.” (n.d.). In Ni Una Menos’ website. Retrieved from http://niunamenos.org.ar/quienes-somos/carta-organica/

Cho, S., Crenshaw, K., \& McCall, L. (2013). Toward A Field of Intersectionality Studies: Theory, Applications, and Praxis. Signs, 38(4), 785-810.

Collins, P. H. (1998). The Tie That Binds: Race, Gender and U.S. Violence. Ethnic and Racial Studies, 21(5), 918-938.

Collins, P. H. (2017). On Violence, Intersectionality and Transversal Politics. Ethnic and Racial Studies, 40(9), 1460-1473.

Colon, A., \& Poggio, S. (2010). Women's Work and Neoliberal Globalization. In E. Maier, \& N. Lebon (Eds.), Women's Activism in Latin America and the Caribbean: Engendering Social Justice, Democratizing Citizenship (pp. 47-59). New Jersey, USA: Rutgers University Press.

Couldry, N. \& Curran, J. (2003). Contesting media power: Alternative media in a networked world. Maryland: Rowman \& Littlefield Publishers.

Crenshaw, K. (1989). Demarginalizing the Intersection of Race and Sex: A Black Feminist Critique of Antidiscrimination Doctrine, Feminist Theory and Antiracist Politics. University of Chicago Legal Forum, 1989(1), 139-167.

Crenshaw, K. (1991). Mapping the margins: Intersectionality, identity politics, and violence against women of color. Stanford Law Review, 43(6), 1241-1299.

Creswell, J. W. (2012). Qualitative inquiry and research design: Choosing among five 
approaches. Sage.

Crettaz, J. (2017, April 15). El periodismo argentino y la urgencia por dejar de hacer lo mismo de siempre. La Nación. Retrieved from:

https://www.lanacion.com.ar/2008788-el-periodismo-argentino-y-la-urgencia-pordejar-de-hacer-lo-mismo-de-siempre

Davis, K. (2008). Intersectionality as buzzword: A Sociology of Science Perspective on What Makes a Feminist Theory Successful. Feminist Theory, 9(1), 67-85.

Delgado, A. (1995). Agresiones a La Prensa 1991-1994. Buenos Aires, Argentina: Asociación Madres de Plaza de Mayo.

Del Rio, A. (2016, November 7). \#NiUnaMenos: Against Femicide in Latin America. Open Democracy. Retrieved from https://www.opendemocracy.net/democraciaabierta/andr-s-del-r-o/niunamenosagainst-femicide-in-latin-america

Di Marco, G. (2010). Women's movements in Argentina. In E. Maier, \& N. Lebon (Eds.), Women's Activism in Latin America and the Caribbean: Engendering Social Justice, Democratizing Citizenship (pp. 159-174). New Jersey, USA: Rutgers University Press.

Douai, A. (2013). "Seeds of Change" in Tahrir Square and beyond: People Power or Technological Convergence. American Communication Journal, 15(1), 24-33.

Downing, J. D. (2001). Radical Media: Rebellious Communication and Social Movements. Thousand Oaks, CA: Sage Publications. 
Downing, J. D. H. (2005). Activist media, civil society and social movements. In W. de Jong, M. Shaw, \& N. Stammers (Eds.), Global activism, global media (pp. 149164). London: Pluto Press.

Downing, J.D. (2008). Social Movement Theories and Alternative Media: An Evaluation and Critique. Communication, Culture \& Critique, 1, 40-50.

Durham, M. G. (1998). On the Relevance of Standpoint Epistemology to the Practice of Journalism: The Case for "Strong Objectivity." Communication Theory, 8(2), 117140.

Earl, J., \& Kimport, K. (Eds.) (2011). Digitally enabled social change: Activism in the internet age. Cambridge, MA: MIT Press.

Erbentraut, J. (2015, June 12). Argentina May Address Street Harassment of Women With Fines For Catcallers. The Huffington Post. Retrieved from https://www.huffpost.com/entry/argentina-street-harassment-ban_n_7570564

Fairclough, N., \& Wodak, R. (1997). Critical Discourse Analysis. In T. van Dijk, (Ed.), Discourse as Social Interaction. London, U.K.: Sage.

Fenton, N. (2016). Digital, political, radical. Malden, MA: Polity.

Fernandes, L. (2013). Transnational Feminism in the United States: Knowledge, Ethics, Power. New York, NY: New York University Press.

Foley, D.E. (2002). Critical ethnography: the reflexive turn. Qualitative Studies in Education, 15(5), 469-490.

Foley, D.E. \& Valenzuela, A. (2005). Critical ethnography: politics of collaboration. In N.K. Denzin and Y.S. Lincoln (Eds), The Sage Handbook of Qualitative Research, pp. 217-234. Thousand Oaks, CA: Sage. 
Freedman, D. (2014). The contradictions of media power. Bloomsbury Publishing.

Freeman, C., \& Murdock, D. (2001). Enduring Traditions and New Directions in Feminist Ethnography in the Caribbean and Latin America. Feminist Studies, 27(2), 423-458.

Friedman, E. J. (2017). Interpreting the internet: Feminist and queer counterpublics in Latin America. Oakland, CA: University of California Press.

Galperín, H. (2002). Transforming Television in Argentina: Market Development and Policy Reform in the 1990s. In E. Fox and S. Waisbord (Eds.), Latin Politics, Global Media, pp. 22-37. Austin, TX: University of Texas Press.

Gerring, J. (2007). Case study research: Principles and practices. Cambridge University Press.

Gill, R. (2000). Discourse Analysis. In M. Bauer, \& G. Gaskell (Eds.) Qualitative Researching with Text, Image and Sound: A Practical Handbook for Social Research, pp. 172-190. London, U.K.: SAGE Publications.

Gitlin, T. (2003). The whole world is watching: Mass media in the making and unmaking of the new left (2nd ed). Berkeley, CA: University of California Press.

Goñi, U. (2017, April 28). 40 years later, the mothers of Argentina's 'disappeared' refuse to be silent. The Guardian. Retrieved from https://www.theguardian.com/world/2017/apr/28/mothers-plaza-de-mayoargentina-anniversary

Gordon, S. (2016, October 21). NiUnaMenos: How the brutal gang rape and murder of a schoolgirl united the furious women of Latin America. The Telegraph. Retrieved 
from http://www.telegraph.co.uk/women/life/niunamenos-how-a-schoolgirlsbrutal-gang-rape-and-murder-united/

Gramsci, A. (1992). Prison notebooks (Vol. 2). New York: Columbia University Press.

Haas, T. (2004). Qualitative case study methods in newsroom research and reporting. Qualitative research in journalism: Taking it to the streets, 59.

Hall, S. (1980). Cultural studies: Two paradigms. Media, Culture \& Society, 2(1), 57-72.

Hall, K., \& Bucholtz, M. (1995). Gender articulated: Language and the socially constructed self. New York: Routledge.

Hallin, D. C., \& Mancini, P. (2004). Comparing media systems: Three models of media and politics. Cambridge: Cambridge University Press.

Hallin, D. C., \& Mancini, P. (2011). Comparing media systems beyond the Western world. Cambridge: Cambridge University Press.

Hamel, J., Dufour, S., \& Fortin, D. (1993). Case study methods (Vol. 32). London: Sage.

Hancock, A. M. (2007). When Multiplication Doesn’t Equal Quick Addition: Examining Intersectionality as a Research Paradigm. Perspectives on Politics, 5(1), 63-79.

Harding, S. G. (1993). Rethinking standpoint epistemology: What is "strong objectivity?" In L. Alcoff \& E. Potter (Eds.), Feminist Epistemologies, 49-82. New York City, NY: Routledge.

Hasan, V. F. (2012). Periodismo feminista en la web y estrategias en el uso de las TICs: construcción de agenda y producciones contradiscursivas. In Actas III Jornadas Internacionales de Problemas Latinoamericanos Movimientos Sociales, Estados y Partidos Políticos en América Latina: (re)configuraciones institucionales, 
experiencias de organización y resistencia. Mendoza: Universidad Nacional Cuyo.

Hasan, V. F., \& Gil, A. S. (2014). Estrategias del Periodismo Feminista: Prácticas y Política en la Reconfiguración del Espacio Comunicacional. Perspectivas de la Comunicación, 7(2), 42-54.

Hine, C. (2000). Virtual ethnography. London: Sage.

Hine, C. (2015). Ethnography for the internet: Embedded, embodied and everyday. London: Bloomsbury Publishing.

Horkheimer, M. (1982). Critical Theory. New York, NY: Seabury Press.

Howard, P.N. et al. (2011). Opening Closed Regimes: What Was the Role of Social Media During the Arab Spring? Project of Information Technology \& Political Islam. Retrieved from https://deepblue.lib.umich.edu/bitstream/handle/2027.42/117568/2011_HowardDuffy-Freelon-Hussain-Mari-Mazaid_PITPI.pdf?sequence=1\&isAllowed=y

Jasper, J. M. (2010). Cultural approaches in the sociology of social movements. In B. Klandermans and C Roggeband (Eds.), Handbook of social movements across disciplines. (pp. 59-109). Boston, MA: Springer.

Jelin, E. (1994). The politics of memory: The human rights movement and the construction of democracy in Argentina. Latin American Perspectives, 21(2), 3858.

Knudson, J.W. (1997). Veil of silence: The Argentine press and the dirty war, 1976-1983. Latin American Perspectives, 24(6), 93-112.

Kozinets, R. V. (2010). Netnography: The marketer's secret weapon. White Paper. 
Lazar, M. (2007). Feminist critical discourse analysis: Articulating a feminist discourse praxis. Critical Discourse Studies, 4(2), 141-164.

Lebon, N. (2010). Women Building Plural Democracy in Latin America and the Caribbean. In E. Maier and N. Lebon (Eds.), Women's Activism in Latin America and the Caribbean, (pp. 3-25). London: Rutgers University Press.

Lewis, P. (2009). The Agony of Argentine Capitalism: From Menem to the Kirchners. Santa Barbara, CA: Praeger.

Lievrouw, L. A. (2011). Alternative and Activist New Media. Cambridge, MA: Polity.

Luke, P. (2005). Ideological Power. London: Sage

Macrory, R. (2013). Dilemmas of Democratisation: Media Regulation and Reform in Argentina. Bulletin of Latin American Research, 32(2), 178-193.

Maier, E. (2010). Accommodating the Private into the Public Domain: Experiences and Legacies of the Past Four Decades. In E. Maier, \& N. Lebon (Eds.), Women's Activism in Latin America and the Caribbean: Engendering Social Justice, Democratizing Citizenship, pp. 26-43. New Jersey: Rutgers University Press.

Mani, L. (1998). Contentious Traditions: The Debate on Sati in Colonial India. Berkeley, CA: University of California Press.

Manning, J. (2016). Constructing a postcolonial feminist ethnography. Journal of Organizational Ethnography, 5(2), 90-105.

Marino, S. (2009). Argentina. In AMARC (Ed.), Las mordazas invisibles. Nuevas y viejas barreras a la diversidad en la radiodifusión, pp. 55-85. Buenos Aires, Argentina: AMARC ALC. 
Marx Ferree, M. (2006). Globalization and Feminism: Opportunities and Obstacles. In M.

Marx Ferree \& A. M. Tripp (Eds.), Global feminism: transnational women's activism, organizing, and human rights, (pp. 3-23). New York: New York University Press.

Mauersberger, C. (2011). Whose voice gets on air? The role of community radio and recent reforms to democratize media markets in Uruguay, Argentina, and Chile. Journal of Latin American Communication Research, 1(2), 23-47.

McCall, L. (2005). The complexity of intersectionality. Signs: Journal of women in culture and society, 30(3), 1771-1800.

McCorkel, J.A. \& Myers, K. (2003). What difference does difference make? Position and privilege in the field. Qualitative Sociology, 26(2), 199-231.

Minh-ha, T. (2000). Speaking Nearby: A Conversation with Trinh T. Minh-ha. By Nancy N. Chen. In E. Ann Kaplan (Ed.), Feminism and Film, (pp. 317-335). Oxford: Oxford University Press.

Mische, A. (2003). Cross-talk in movements: Reconceiving the culture-network link. In M. Diani and D. McAdam (Eds.), Social Movements and Networks: Relational Approaches to Collective Action, (pp. 258-280). Oxford: Oxford University Press.

Mohanty, C.T. (2003). Feminism Without Borders: Decolonizing Theory, Practicing Solidarity. Durham, NC: Duke University Press.

Morozov, E. (2009). Iran: Downside to the" twitter revolution". Dissent, 56(4), 10-14. Morozov, E. (2011). The Net Delusion: The Dark Side of Internet Freedom. Jackson, TN: Public Affairs. 
Nari, M. M. A. (1996). “Abrir los ojos, abrir la cabeza”: el feminismo en la Argentina de los años '70. Feminaria, 9(17-18), 15-22.

Nip, J. Y. (2004). The relationship between online and offline communities: The case of the Queer Sisters. Media, Culture \& Society, 26(3), 409-428.

NUMArgentina. (2016, March 26). In Facebook [Fan page]. Retrieved February 10, 2019 from https://www.facebook.com/NUMArgentina/posts/465200360337818/

Ong, A. (2001). Colonialism and Modernity: Feminist Re-Presentations of Women in Non-Western Societies. In Kum-Kum Bhavnani (Ed.), Feminism and Race, (pp. 108-118). Oxford: Oxford University Press.

Ozkazanc-Pan, B. (2012). Postcolonial feminist research: challenges and complexities. Equality, Diversity and Inclusion: An International Journal, 31(5/6), 573-591.

Papacharissi, Z., \& Oliveira, M. (2012). Affective News and Networked Publics: The Rythms of News Storytelling on \#Egypt. Journal of Communication, 62, 266-282.

Park, D. (2002). Media, Democracy, and Human Rights in Argentina. Journal of Communication Inquiry, 26(3), 237-260.

Piaget, J. (1971). Structuralism. New York City, NY: Harper \& Row.

Ramazanoglu, C., \& Holland, J. (2002). Feminist methodology: Challenges and choices. Sage.

Rodríguez, C. (2001). Fissures in the mediascape: An international study of citizens' media. Cresskill, NJ: Hampton Press.

Rodríguez, C., Ferron, B., Shamas, K. (2014). Four challenges in the field of alternative, radical and citizens' media research. Media, Culture \& Society, 36(2), 150-166. 
Rodríguez, P. (2015). Ni Una Menos [E-reader versión, if aplicable]. Doi: 978-950-494905-3.

Rofman, A. (2000). El Estado y las mujeres: articulación entre demandas y políticas de género. In S. Hintze (Ed.), Estado y Sociedad. Las políticas sociales en los umbrales del siglo XXI, pp. 205-223. Buenos Aires, Argentina: Eudeba.

Rosemberg, J. (2016, August 11). Macri evitó precisar la cifra de desaparecidos y generó rechazos. La Nación. Retrieved from https://www.lanacion.com.ar/politica/macrievito-precisar-la-cifra-de-desaparecidos-y-genero-rechazos-nid1926868

Rothschild-Whitt, J. (1979). The collectivist organization: An alternative to rationalbureaucratic models. American Sociological Review, 509-527.

Ryan, C. (1991). Prime time activism: Media strategies for grassroots organizing. South End Press.

Said, E. (1978). Orientalism. New York, NY: Pantheon.

Schrock, R.D. (2013). The Methodological Imperatives of Feminist Ethnography. Journal of Feminist Scholarship, 5, 48-60.

Shirky, C. (2008). Here comes everybody: The power of organizing without organizations. Penguin.

Spivak, G. C. (1988). Can the Subaltern Speak? In B. Ashcroft, G. Griffiths, and H. Tiffin (Eds.), The Post-Colonial Studies Reader (pp. 24-28). New York, NY: Routledge.

Stacey, J. (1988). Can There Be a Feminist Ethnography? Women's Studies International Forum 11(1), 21-27.

Stake, R. E. (1995). The art of case study research. London: Sage. 
Stewart, A. (1998). The ethnographer's method. Thousand Oaks, CA: Sage.

Swanborn, P. (2010). Case study research: What, why and how? London: Sage.

Tarducci, M., \& Rifkin, D. (2010). Fragmentos de historia del Feminismo en Argentina. En Chaher y Santoro (Eds.) Las palabras tienen sexo II, pp. 17-39. Buenos Aires, Artemisa Comunicación Ediciones.

Thompson, J. (1995). Forms of Power: The political, economic, coercive and symbolic. New York: Routledge.

Tilly, C., \& Tarrow, S. (2007). Contentious politics. Oxford, UK: Oxford University Press.

Tripp, A. M. (2006). The Evolution of Transnational Feminisms: Consensus, Conflict, and New Dynamics. In M. Marx Ferree \& A. M. Tripp (Eds.), Global feminism: transnational women's activism, organizing, and human rights (pp. 51-75). New York: New York University Press.

Trottier, D., \& Fuchs, C. (Eds.) (2014). Social media, politics and the state: Protests, revolutions, riots, crime and policing in the age of Facebook, Twitter and Youtube. London: Routledge.

Tufekci, Z. (2017). Twitter and tear gas: The power and fragility of networked protest. New Haven, CT: Yale University Press.

Tufekci, Z., \& Wilson, C. (2012). Social media and the decision to participate in political protest: Observations from Tahrir Square. Journal of communication, 62(2), 363379.

United Nations. (1996). Platform for Action and the Beijing Declaration. New York: UN. 
Van de Donk, W., Loader, B. D., Nixon, P. G., \& Rucht, D. (2004). Cyberprotest: New media, citizens and social movements. New York: Routledge.

van Dijk, T. (1993). Principles of Critical Discourse Analysis. Discourse \& Society, 4(2), 249-283.

Van Laer, J., \& Van Aelst, P. (2010). Internet and social movement action repertoires: Opportunities and limitations. Information, Communication \& Society, 13(8), $1146-1171$.

Vialey, P., Belinche, M., \& Tovar, C. (2008). The Media in Argentina: Democracy, Crisis and the Reconfiguration of Media Groups. In J. Lugo-Ocando (Ed.), The Media in Latin America, pp. 13-28. Berkshire, UK: Open University Press.

Waisbord, S. (2018). Revisiting mediated activism. Sociology Compass, 12(6), 1-9. doi: $10.1111 / \operatorname{soc} 4.12584$

Wolfsfeld, G., Segev, E, \& Sheafer, T. (2013). Social Media and the Arab Spring: Politics Comes First. The International Journal of Press/Politics, 18(2), 115-137.

Wodak, R. (1997). Gender and discourse. London: Sage.

Wodak, R. (2008). Discourse Studies: Important Concepts and Terms. In R. Wodak, \& M. Krzyzanowski (Eds.), Qualitative Discourse Analysis in the Social Sciences, 1-29, New York, U.S.A.: Palgrave Macmillan.

Wodak, R. (2009). The Discourse of Politics in Action: Politics as usual. Houndmills, U.K.: Palgrave Macmillan.

Wodak, R., \& Meyer, M. (2009). Critical Discourse Analysis: History, Agenda, Theory and Methodology. In R. Wodak, \& M. Meyer (Eds.), Methods of Critical Discourse Analysis, 1-33, Thousand Oaks, CA: Sage. 
Wojcieszak, M. (2009). "Carrying online participation offline"-Mobilization by radical online groups and politically dissimilar offline ties. Journal of Communication, 59(3), 564-586.

Yates, L. (2015). Rethinking Prefiguration: Alternatives, Micropolitics and Goals in Social Movements. Social Movement Studies, 14(1), 1-21.

Yeatman, A. (2000). Who is the Subject of Human Rights? American Behavioral Scientist, 43(9), 1498-1513.

Yin, R. K. (2009). Case study research: Design and methods (Vol. 5). London: Sage. Yuval-Davis, N. (1997). Gender and Nation. Thousand Oaks, CA: Sage.

Yuval-Davis, N. (1999). What Is 'Transversal Politics'? Soundings, 12, 94-98. 


\section{APPENDIX A}

\section{Interview Protocol}

\section{Organizational components}

1. How did Ni Una Menos become a feminist collective?

2. Why did you decide to form a collective instead of another type of organization?

3. What differentiates Ni Una Menos from other feminist and women's organizations operating in Argentina?

4. What is the relationship between Ni Una Menos and other feminist and women's organizations?

5. How would you describe the culture at the collective Ni Una Menos?

6. How would you describe the organizational structure of the collective?

7. How are decisions made in the collective?

8. What are the advantages and disadvantages of organizing as a collective?

\section{Feminist stance and interventions}

1. What is your definition of feminism?

2. What would you say are the main goals of feminism?

3. Has your understanding of feminism changed because of your involvement with Ni Una Menos? How?

4. How do you define intersectionality?

5. How does intersectionality apply to the Argentine context?

6. How does Ni Una Menos advance intersectional feminist politics?

7. What would you say are the main goals of Ni Una Menos?

8. What is the biggest obstacle Ni Una Menos faces?

a. Internal (from the collective's own ranks and base).

b. External (from outside the collective's own ranks and base).

9. Has there been a topic or occurrence that threatened to divide the collective or its base? How was the situation resolved?

10. How does the collective deal with potentially dividing identifications, such as:
a. partisanship,
b. religious beliefs,
c. class stratification,
d. racial stratification (including the status of indigenous peoples),
e. sexual identification and orientation, and
f. indigenous status.

11. What role does the state play in the advance or hindrance of feminist politics? 
12. What role does the journalism play in the advance or hindrance of feminist politics?

\section{Ni Una Menos and media}

1. How important is the use of social media and other digital communication technologies in the activities of Ni Una Menos?

2. How would you describe the online presence of $\mathrm{Ni}$ Una Menos?

3. How do feminist politics become evident in the online presence of $\mathrm{Ni}$ Una Menos?

4. What role do social media and other digital communication technologies play in Ni Una Menos?

5. How do social media and other digital communication technologies shape the work of Ni Una Menos?

a. How do social media and other digital communication technologies contribute to the work of Ni Una Menos?

b. How do social media and other digital communication technologies hinder the work of Ni Una Menos?

6. Would you say your feminist politics influence the way you engage in social and digital media? How?

7. How significant, if at all, is the fact that many of the founders of Ni Una Menos are journalists or media professionals?

8. How significant is a feminist intervention of journalism and media for $\mathrm{Ni}$ Una Menos?

9. What is feminist journalism?

10. How are the values and practices of feminist journalism different from the journalism that has been practiced in Argentina so far? 


\section{APPENDIX B}

\section{Vita}

Ayleen Cabas-Mijares is a doctoral candidate at the Missouri School of

Journalism. She was born in Venezuela and completed her undergraduate studies in mass communication there. After spending four years as a reporter and copy editor of a national women's magazine in Venezuela, she moved to the United States to pursue her graduate studies. In 2016, she earned her Master's in Journalism at the E.W. Scripps School of Journalism at Ohio University.

Cabas-Mijares applies critical/cultural and transnational theories to the study of media, journalism, and social movements in the Latin American context. Specifically, she examines how activists navigate media systems and use traditional and new media to further their political agenda. In fall 2019, Cabas-Mijares will start as an assistant professor of journalism at the Diederich College of Communication at Marquette University. 